\title{
Middle Jurassic (Bathonian) Ammonites From Southern Alaska
}

GEOLOGICAL SURVEY PROFESIONAL PAPER-1091

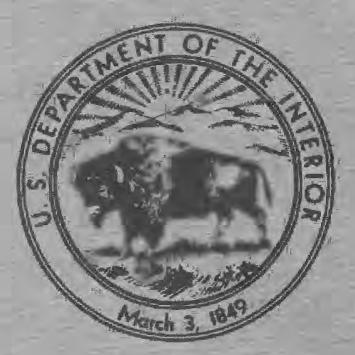




\section{Middle Jurassic (Bathonian) Ammonites From Southern Alaska}

By RALPH W. IMLAY

GEOLOGICAL SURVEY PROFESIONAL PAPER 1091

Studies of Bathonian ammonites from southern Alaska provide correlations with the arctic region in general, with the Pacific coast and western interior regions of North America, and with the early Bathonian of some other parts of the world

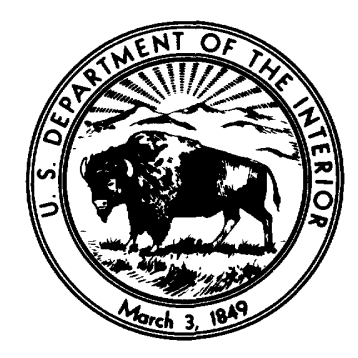

UNITED STATES GOVERNMENT PRINTING OFFICE, WASHINGTON : 1980 
UNITED STATES DEPARTMENT OF THE INTERIOR

CECIL D. ANDRUS, Secretary

GEOLOGICAL SURVEY

H. William Menard, Director

Library of Congress Cataloging in Publication Data

Imlay, Ralph Willard, 1908-

Middle Jurassic (Bathonian) ammonites from southern Alaska.

(Geological Survey professional paper; 1091)

Bibliography: $p$.

Includes index.

1. Ammonoidea. 2. Paleontology—Jurassic. 3. Paleontology-Alaska. I. Title. II. Series: United States. Geological Survey. Professional paper; 1091. QE807.A5I616

$564^{\prime} .53$

$78-16661$

For sale by the Superintendent of Documents, U.S. Government Printing Office Washington, D.C. 20402

Stock Number 024-001-03284-8 


\section{CONTENTS}

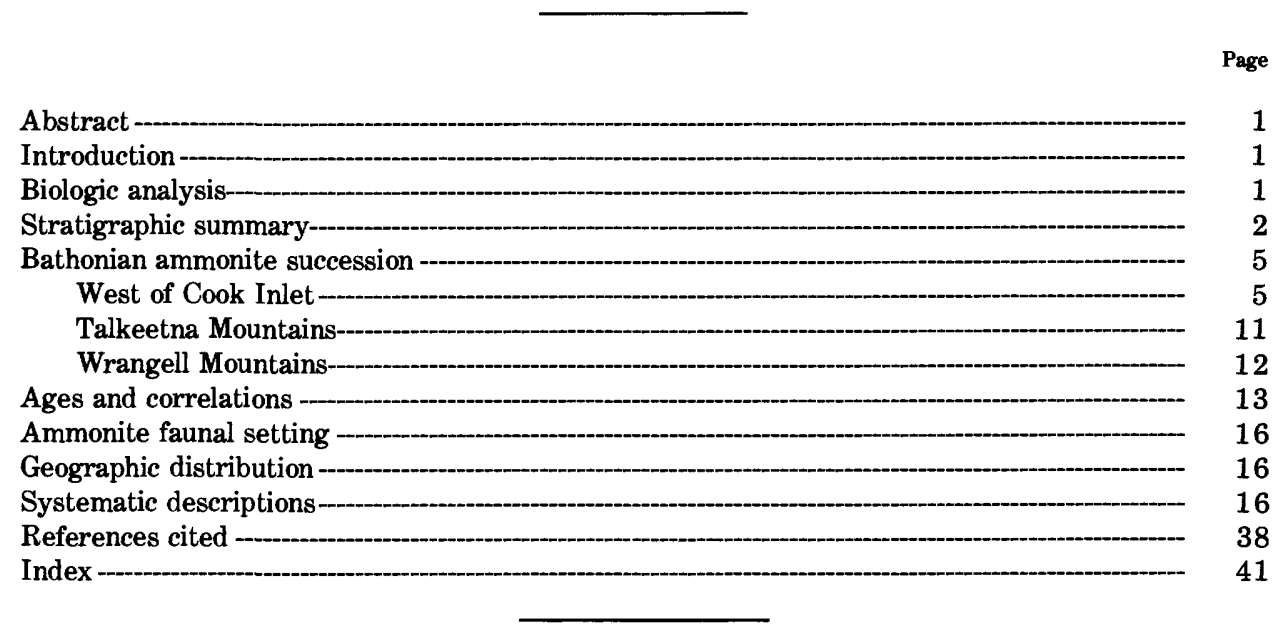

\section{ILLUSTRATIONS}

[Plates 1-12 follow index]

Plate 1. Kepplerites, Phylloceras, Calliphylloceras, and Macrophylloceras.

2. Xenocephalites and Lytoceras.

3. Oppelia (Oxycerites), O. (Liroxyites), Cranocephalites, and Kepplerites.

4. Cadomites.

5. Cranocephalites.

6. Cranocephalites.

7. Cranocephalites.

8. Tuxednites, Tuxednites?, Arctocephalites, and Iniskinites.

9. Talkeetnites.

10. Parareineckeia.

11. Parareineckeia.

12. Cobbanites.

\section{FIGURE 1. Index map showing principal areas of outcrop of Bathonian marine rocks in southern Alaska}

2. Diagram showing stratigraphic positions of ammonite localities in the Bowser Formation west of Cook Inlet between Tuxedni Bay and Iniskin Bay-

3. Diagram showing stratigraphic positions of some Bathonian ammonite localities in the Talkeetna Mountains

4. Diagram showing part of the Middle Jurassic sequence exposed on northwest-trending divide at head of a tributary of Boulder Creek near center of NW1/4SE1/4 sec. 26, T. 22 N., R. 7 E., Anchorage D-3 quadrangle, Talkeetna Mountains, Alaska -

5. Diagram showing stratigraphic ranges of Bathonian ammonites in the Bowser Formation west of Cook Inlet--

6. Diagram showing stratigraphic ranges of Bathonian ammonites in unnamed beds in the Talkeetna Mountains--..........

7. Chart showing correlation of Bathonian formations and faunas in southern Alaska-

8-11. Index maps of listed Bathonian fossil localities in southern Alaska:

8. In the Wrangell Mountains

9. In the Talkeetna Mountains

10. West of Cook Inlet between Tuxedni Bay and Chinitna Bay

11. West of Cook Inlet on the Iniskin Peninsula 


\section{TABLES}

TABLE 1. Bathonian ammonite genera in southern Alaska showing biological relationships and relative numbers available for study --.-

2. Geographic distribution of Bathonian ammonites in the Wrangell and the Talkeetna Mountains, Alaska

3. Geographic distribution of Bathonian ammonites between Tuxedni Bay and Iniskin Bay west of Cook Inlet, Alaska-_-_-_-_-_.-.

4. Description of Bathonian fossil localities in southern Alaska-

\section{CONVERSION FACTORS}

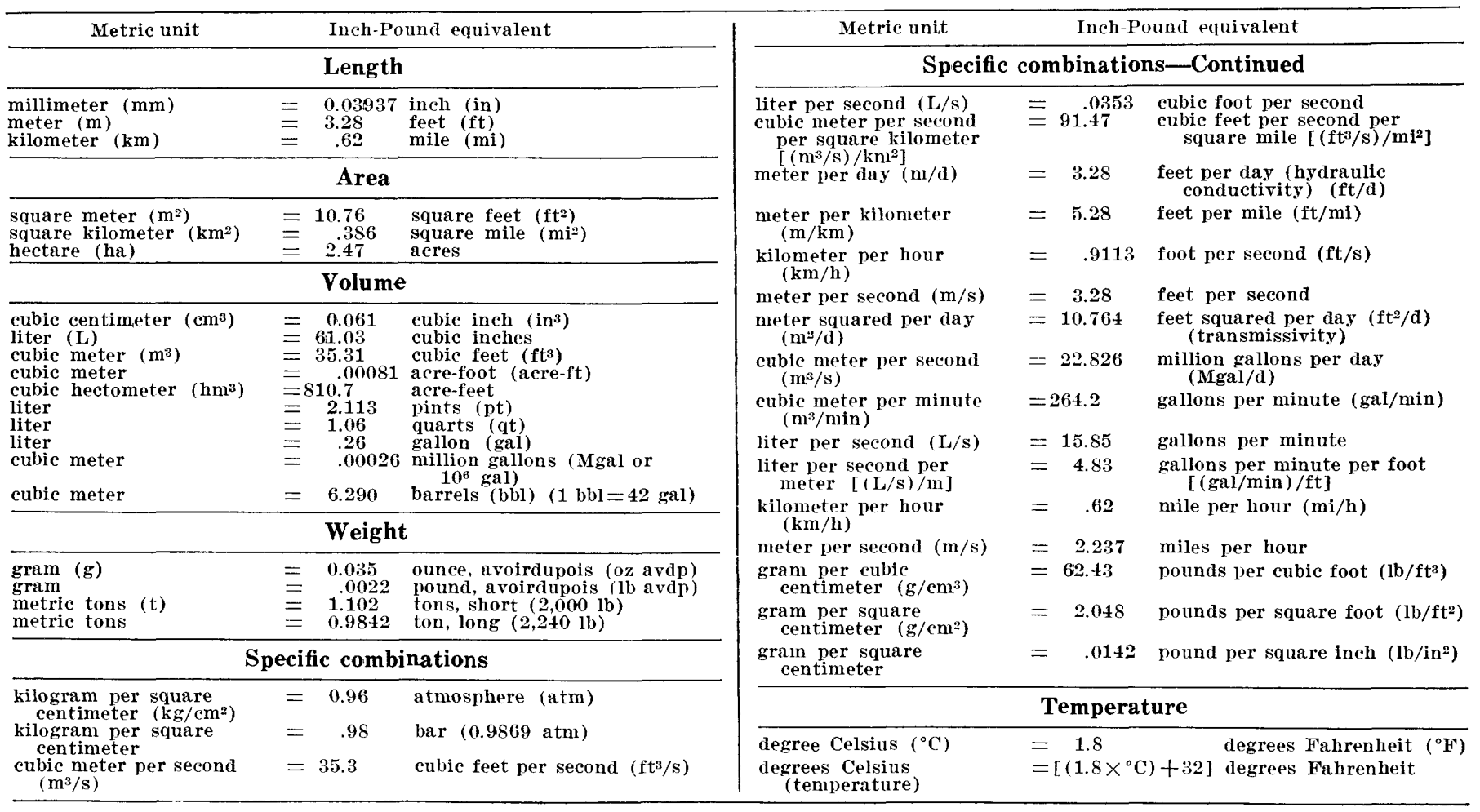




\title{
MIDDLE JURASSIC (BATHONIAN) AMMONITES FROM SOUTHERN ALASKA
}

\author{
By Ralph W. Imlay
}

ABSTRACT

The Bathonian ammonites of southern Alaska include (1) some genera characteristic of the Boreal realm, such as Kepplerites, Arctocephalites, and Cranocephalites; (2) some genera that occur nearly worldwide except in the Boreal realm, such as Cadomites and Siemeradzkia; and (3) many genera that are known only in the Pacific coast region of Alaska or in areas farther south. Those taxa found to date only in southern Alaska include Tuxednites n. gen., Talkeetnites n. gen., and Chinitnites. Those taxa found in the Pacific coast region from Alaska to Oregon include Parareineckeia, Cobbanites, and Iniskinites. Of these, Cobbanites occurs also in the western interior region. In addition, Xenocephalites occurs along the Pacific coast of both North and South America as well as in the western interior region of North America.

Ammonites of Bathonian Age in southern Alaska occur in the Bowser Formation west of Cook Inlet, in unnamed beds in the Talkeetna Mountains, and in the Nizina Mountain Formation in the Wrangell Mountains. These lithologic units are dated as Bathonian mainly by the presence of (1) a sequence of ammonites similar to those in northern Canada, northern Alaska, and East Greenland; (2) Cadomites in the lower part of the unnamed beds in the Talkeetna Mountains and in the Nizina Mountain Formation in the Wrangell Mountains; (3) Siemeradzkia in the lower part of the Bowser Formation west of Cook Inlet; (4) Kepplerites not associated with Cadoceras in the uppermost part of the Bowser Formation; (5) Cobbanites of the Leptosphinctinae throughout most of the Bowser Formation but mostly in the lower part; and (6) the lithologic units in question in the Talkeetna Mountains and west of Cook Inlet lying unconformably below beds of early Callovian Age.

More detailed dating of the Bowser Formation and equivalent units in southern Alaska is made possible by the ammonites that are not known solely from the Pacific coast region. The succession of such ammonites from the base upward is characterized (1) by many specimens of Cranocephalites costidensus (Imlay) in association with rare occurrences of Siemeradzkia and Cadomites; (2) next higher, by species of Cranocephalites similar to $C$. ignekensis Imlay from northern Alaska and to C.vulgaris Spath from the Arctic region; (3) next higher, by Arctocephalites similar to A. elegans Spath from the Arctic region; and (4) at the top, by weakly to nontuberculate species of Kepplerites that are not associated with Cadoceras.

Concerning this succession, the lowermost part is probably of early Bathonian rather than latest Bajocian Age as shown by the presence of Siemeradzkia and a species of Cadomites similar to $C$. rectelobatus (von Hauer). It cannot be younger than early Bathonian as indicated by the presence of $C$. cf. C. deslongchampsi (d'Orbigny). The fact that the associated Cobbanites belongs to the Bajocian subfamily Leptosphinctinae favors a late Bajocian Age but does not prove such an age because the genus also occurs much higher near the top of the Bowser Formation.

The next higher part of the succession characterized by the highest occurrences of Cranocephalites is dated as late early Bathonian on the basis that similar species occur in East Greenland at a similar stratigraphic position. Likewise, the overlying part characterized by Arctocephalites is dated as probably middle Bathonian by comparisons with East Greenland. The highest part characterized by Kepplerites that is not associated with Cadoceras may be equivalent in East Greenland to the lowermost occurrence of Kepplerites in the upper part of the range of Arctioceras just below the lowermost occurrence of Cadoceras. Apparently the uppermost Bathonian in East Greenland that contains both Kepplerites and Cadoceras is represented in southern Alaska either by an unconformity at the base of the Chinitna Formation or by the basal part of the Chinitna Formation that contains the uppermost occurrences of Iniskinites intermedius (Imlay).

\section{INTRODUCTION}

The Bathonian ammonites of southern Alaska, partially described by the writer (Imlay, 1962a), have been restudied to reevaluate the stratigraphic distribution of genera and species, to establish regional and intercontinental correlations, and to date the lithologic units more precisely in terms of the standard Bathonian zones of western Europe. This study is based on biostratigraphic data compiled by Detterman and Hartsock (1966, p. 3640) for the Bowser Formation west of Cook Inlet; by Arthur Grantz (1965; written commun., 1972) for equivalent unnamed beds in the Nelchina area of the Talkeetna Mountains; by R. L. Detterman and the writer, 1972 and 1974 (unpub. data), for equivalent beds in the Boulder Creek area of the Talkeetna Mountains; and by E. M. MacKevett, Jr., (1963, unpub. data; 1969, p. A42-A45; 1971 , p. 16, 17) for the Nizina Mountain Formation in the Wrangell Mountains. The writer took part in field studies west of Cook Inlet with D. J. Miller in 1948 and with R. L. Detterman in 1974; in the Talkeetna Mountains with Arthur Grantz in 1952 and with R. L. Detterman in 1972 and 1974; and in the Wrangell Mountains with E. M. MacKevett, Jr., in 1962. Many thanks are due all these geologists for collecting the fossils and for furnishing accurate fossil locality and stratigraphic data.

\section{BIOLOGIC ANALYSIS}

Southern Alaska ammonites of Bathonian, or probably Bathonian, Age that are discussed or described herein, number 343 specimens. Some of these were described in 
1962 (Imlay, 1962a), but most were obtained subsequently from the Wrangell and Talkeetna Mountains and from the north side of Cook Inlet between Iniskin Bay and Tuxedni Bay. Their distribution by genus, subfamily, and family is shown herein table 1 . Among the families, the Cardioceratidae constitutes 60 percent of the total number of specimens; the Reineckeiidae?, 18 percent; the Perisphinctidae, nearly 8 percent; and the Phylloceratidae, 6 percent. The Cardioceratidae is dominated by Cranocephalites and comprises six genera, of which Tuxednites and Talkeetnites are recognized as new.

The characteristics of most of the genera and subgenera present have been described adequately in fairly recent publications. Liroxyites has been described by Imlay (1962b, p. A-8); Cadomites, by Arkell (1952, p. 79, 80), Arkell and others (1957, p. L290), and Kopik (1974, p. 12, 13); Cranocephalites and Arkelloceras, by Arkell and others (1957, p. L301) and Imlay (1962a, p. C2; 1976, p. 2); Chinitnites and Iniskinites, by Imlay (1975, p. $17,18,23)$; and Parareineckeia, by Imlay (1962a, p. C-25) and Bourquin (1968, p. 160).

Cobbanites is now assigned to the subfamily Leptosphinctinae, instead of the Zigzagiceratinae, at the suggestion of John Callomon (1971, written commun.). This assignment is based on the presence of deep forwardly inclined constrictions, of slightly to strongly forwardly inclined ribs that arch adorally and weaken on the venter, and of lateral tubercles on the inner whorls of some species. Within the Leptosphinctinae, Cobbanites may be distinguished from Leptosphinctes proper by its much coarser ribbing and larger size (Buckman, 1920, pls. 160,

TABLE 1.-Bathonian ammonite genera in southern Alaska showing biological relationships and relative numbers available for study

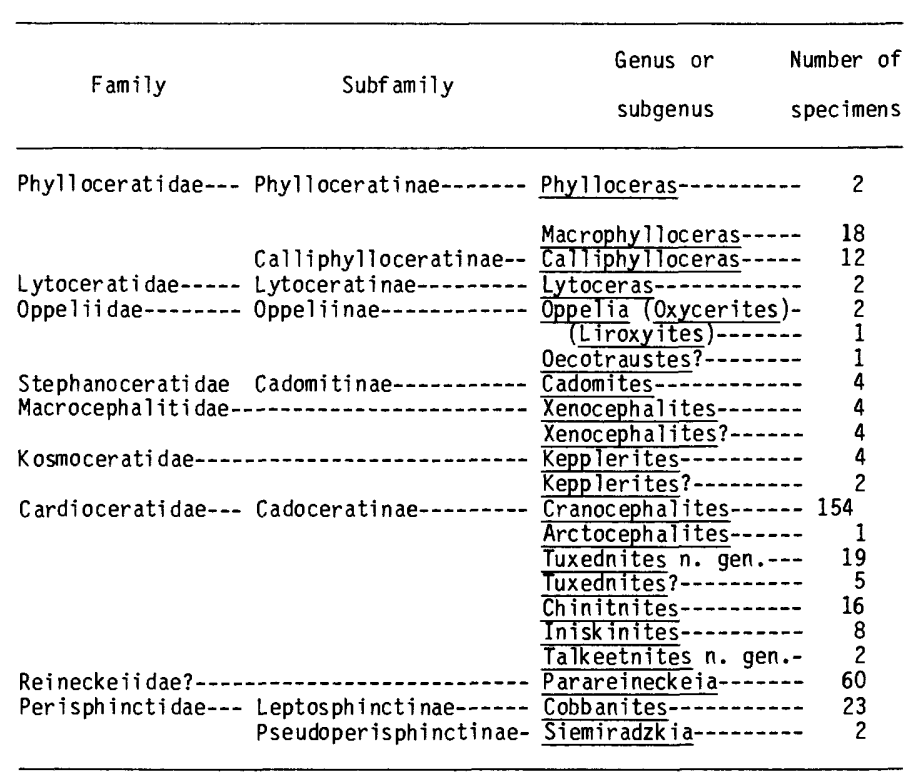

161; 1921, pls. 201, 202); from Prorsisphinctes by the presence of tubercles on its inner whorls, much more compressed whorls, and considerably weaker ribbing on its outermost septate whorl (Buckman, 1921, pls. 200, $247 ; 1922$, pl. 326; 1923, pl. 366; 1927, pl. 446a, b; Sturani, 1964, pl. 4, fig. 1); and from Vermisphinctes by its considerably larger size (Buckman, 1920, pls. 162, 190), by more distinct tubercles on the inner whorls of some species, by more definite weakening of ribs along the midline of the venter, and perhaps by the presence of lateral lappets (Arkell, 1958, p. 168).

These resemblances show that Cobbanites is closely related to Leptosphinctes and its subgenera and is possibly a descendant of Vermisphinctes. Nonetheless, Cobbanites is herein retained as a distinct genus because it does not fit precisely morphologically with either Vermisphinctes or Prorsisphinctes and occurs in beds that are mainly or entirely of Bathonian Age, whereas those subgenera are not known above beds of late Bajocian Age (Arkell, 1957, p. L314; Sturani, 1966, p. 9; Pavia and Sturani, 1968, p. 310).

\section{STRATIGRAPHIC SUMMARY}

Bathonian ammonites have been found in southern Alaska west of Cook Inlet, in the southern part of the Talkeetna Mountains, and in the southern part of the Wrangell Mountains (fig. 1 and tables 2-4). On the west side of Cook Inlet between Iniskin Bay and Tuxedni Bay, the Bathonian is represented by the Bowser Formation, which has been described and illustrated in detail by Detterman and Hartsock (1966, p. 35-40,42, pl. 5) and is illustrated herein in figure 2. That formation ranges in thickness from 1,250 to 1,850 feet. It consists of units of siltstone, sandstone, and conglomerate that vary from thick to thin bedded, are commonly massive, change markedly laterally, and became less conglomeratic and finer grained northward. Coquinoid beds containing mostly Inoceramus and Trigonia are common in the sandstone. Ammonite-bearing concretions occur in the siltstone and are fairly common north of Chinitna Bay. The pebbles, cobbles, and boulders in the conglomerates consist mostly of felsite and basalt but include some granitic rocks. The Bowser Formation rests unconformably on the Twist Creek Siltstone or on older Bajocian beds. It is overlain sharply, but apparently conformably, by the Chinitna Formation on the Iniskin Penisula, and unconformably by that formation between Chinitna Bay and Tuxedni Bay.

In the Talkeetna Mountains, the Bathonian is represented in the Boulder Creek and Nelchina areas (fig. 3) by unnamed beds that are overlain unconformably by the Chinitna Formation of early to early middle Callovian Age (Imlay, 1975, p. 7, 14) and are underlain unconformably by beds ranging in age from Early Jurassic (Tal- 


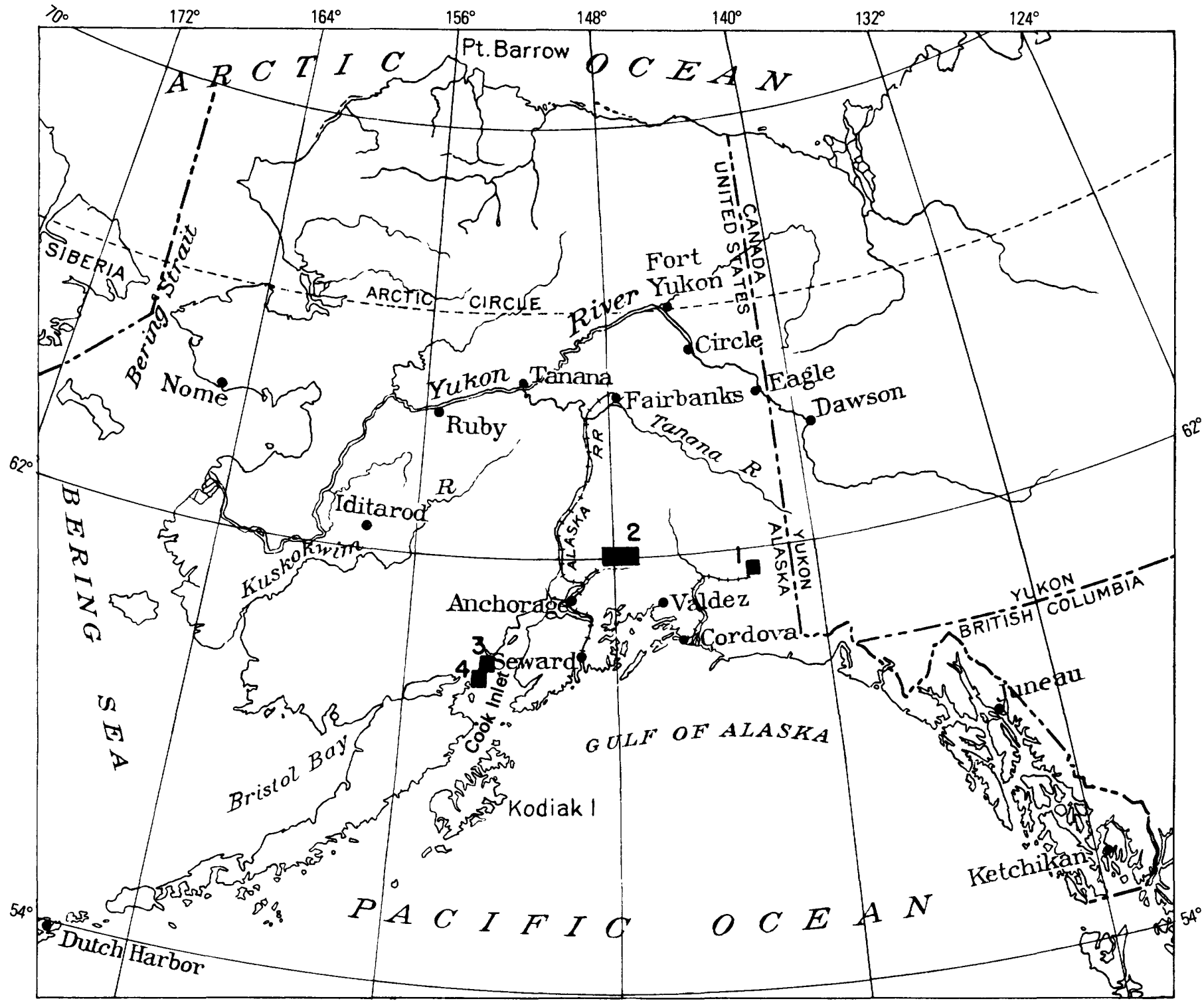

FIGURE 1.-Index map showing principal areas of outcrop of Bathonian marine rocks in southern Alaska. 1, Wrangell Mountains; 2, Talkeetna Mountains; 3, Chisik Island and peninsula between Tuxedni Bay and Chinitna Bay; 4, Iniskin Peninsula.

keetna Formation) to early late Bajocian (uppermost part of Tuxedni Group).

In the Boulder Creek area, the Bathonian unnamed beds are best exposed on a northwest-trending divide (figs. 3 and 4) about 6 miles N. $20^{\circ} \mathrm{E}$. of the junction of East Boulder Creek with the main Boulder Creek. On that divide those beds are about $\mathbf{4 7 5}$ feet thick and consist from top to bottom of 150 feet of volcanic graywacke that includes some beds of coquina, 255 feet of gray to brown concretionary siltstone, and 70 feet of graywacke that includes a few beds of siltstone. Pelecypods and belemnites are fairly common in the coquina beds in the upper volcanic graywacke. Ammonites are abundant in limestone concretions in the siltstone unit and occur rarely in siltstone beds within the lower unit of graywacke.

This lowermost graywacke forms a steep slope above a covered interval about 70 feet thick. Next lower is 30 feet of soft brownish-gray to orange-gray, ash-bearing siltstone that closely resembles the Twist Creek Siltstone west of Cook Inlet (Detterman and Hartsock, 1966, p. 35) and contains the same early late Bajocian ammonites in limy concretions (Imlay, 1962b). Most probably the overlying covered interval is underlain by similar soft siltstone, because identical siltstone attains a thickness of at least 100 feet on a ridge about 1 mile to the 
TABLE 2.-Geographic distribution of Bathonian ammonites [Numbers 1-20 are keyed to locality numbers in figures 8 and 9.

\begin{tabular}{|c|c|c|c|c|c|c|c|c|c|c|c|c|c|}
\hline \multirow{5}{*}{ Genus and species } & \multicolumn{13}{|c|}{ Wrangell Mount ains } \\
\hline & \multicolumn{13}{|c|}{ Nizina Mountain Formation } \\
\hline & \multicolumn{13}{|c|}{ McCarthy C-5 quadrangle } \\
\hline & 1 & 2 & & 3 & 4 & 5 & 6 & 7 & $\varepsilon$ & 8 & 9 & 10 & 11 \\
\hline & 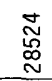 & $\begin{array}{l}\stackrel{N}{N} \\
\underset{\sim}{\sim}\end{array}$ & 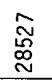 & 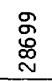 & 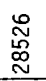 & 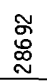 & $\begin{array}{l}\infty \\
\stackrel{\circ}{0} \\
\stackrel{\sim}{0}\end{array}$ & $\begin{array}{l}\stackrel{8}{\circ} \\
\stackrel{\infty}{\infty}\end{array}$ & 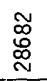 & 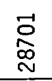 & $\begin{array}{l}\overrightarrow{\mathbf{D}} \\
\stackrel{0}{0} \\
\underset{\sim}{\sim}\end{array}$ & 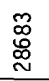 & $\begin{array}{l}\vec{F} \\
\stackrel{0}{0} \\
\text { ] }\end{array}$ \\
\hline Phylloceras (Macrophylloceras) grossicostatum Imlay- & $\cdots$ & -- & -- & -- & -- & -- & -- & -- & -- & -- & -- & -- & -- \\
\hline 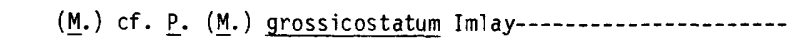 & - & -- & -- & - & - & -- & -- & -- & - & -- & -- & -- & -- \\
\hline Calliphylloceras freibrocki (Iml ay) & -- & -- & -- & -- & -- & -- & -- & -- & -- & -- & -- & -- & -- \\
\hline Lytoceras sp- & -- & -- & -- & -- & -- & -- & -- & -- & -- & -- & -- & -- & -- \\
\hline 0ecotraustes (Paraecotraustes?) sp--.--- & -- & -- & -- & -- & -- & -- & -- & -- & -- & -- & -- & -- & -- \\
\hline Cadomites cf. $\underline{C}$. deslongchampsi (d'Orbigny)-.- & - & -- & -- & -- & - & -- & -- & -- & -- & -- & -- & -- & -- \\
\hline cf. $\underline{c}$. rectolobatum (Hauer) -..-. & - & -- & -- & -- & -- & -- & -- & -- & $x$ & -- & -- & -- & -- \\
\hline Cranocephalites costidensus Imlay-- & -- & -- & -- & -- & -- & -- & -- & -- & $x$ & -- & $x$ & -- & -- \\
\hline 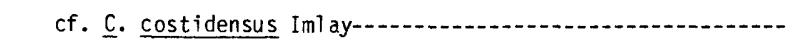 & -- & $x$ & -- & $x$ & -- & -- & -- & -- & -- & -- & -- & -- & -- \\
\hline alask anus Imlay n. sp-................ & -- & -- & -- & -- & -- & -- & -- & -- & $x$ & -- & -- & -- & - \\
\hline cf. $\underline{\text { C. }}$ alask anus $\operatorname{Iml}$ ay $n . \mathrm{sp} \cdots$ & -- & $x$ & $x$ & -- & - & -- & $x$ & -- & -- & -- & $x$ & -- & -- \\
\hline 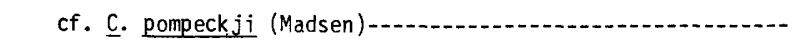 & - & -- & -- & -- & -- & -- & -- & -- & -- & -- & -- & - & -- \\
\hline globosus Iml ay n. sp-.................. & -- & -- & -- & -- & -- & -- & -- & -- & -- & -- & -- & -- & -- \\
\hline cf. $\underline{c}$. vulgaris Spath-........... & - & -- & -- & -- & -- & -- & -- & -- & -- & - & -- & -- & -- \\
\hline Cranocephalites sp-....................... & -- & -- & -- & -- & -- & -- & -- & $x$ & -- & -- & -- & -- & $x$ \\
\hline Tuxednites alticostatus (Imlay) -..... & - & -- & -- & -- & -- & -- & -- & -- & $x$ & -- & -- & -- & -- \\
\hline ? sp- - - - & -- & -- & -- & -- & -- & -- & -- & -- & $x$ & -- & -- & -- & -- \\
\hline Chinitnites sp-...- & -- & -- & - & -- & -- & -- & -- & -- & -- & -- & -- & -- & -- \\
\hline Talkeetnites cadiformis Imlay $n$. sp-- & -- & -- & - & -- & -- & -- & -- & -- & -- & -- & -- & -- & -- \\
\hline Parareineckeia hickersonens is Imlay--- & $x$ & -- & -- & $x$ & -- & -- & $x$ & $x$ & $x$ & $x$ & $x$ & -- & -- \\
\hline nelchinensis Imlay n. sp--- & $x$ & -- & $x$ & -- & -- & -- & -- & -- & $x$ & -- & $x$ & $x$ & -- \\
\hline 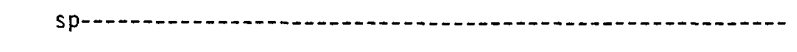 & -- & $x$ & -- & -- & $x$ & $x$ & -- & -- & -- & -- & -- & -- & -- \\
\hline Cobbanites talkeetnanus Imlay-............. & -- & $x$ & -- & $x$ & -- & -- & -- & -- & $x$ & -- & -- & -- & -- \\
\hline$\underline{\text { striatus Imlay } n . s}$ & -- & -- & -- & -- & -- & -- & - & -- & $x$ & -- & -- & -- & -- \\
\hline cf. C. striatus & -- & -- & -- & $x$ & -- & -- & -- & -- & -- & -- & -- & -- & -- \\
\hline
\end{tabular}

southwest in the $\mathrm{SW}_{1 / 4} \mathrm{SE}^{1 / 4}$ sec. 34 , T. 22 N., R. 7 E., and the NW1/4 NE1/4 sec. 3, T. 21 N., R. 7 E.

Unnamed bed of Bathonian Age in the Nelchina area of the Talkeetna Mountains were mapped and briefly described by Grantz (1960a, b; 1965). Some descriptions furnished by Grantz $(1959,1972$, written communs.) were published by Imlay (1962a, p. C4; 1975, p. 2, 3, fig. 3) and are shown herein (fig. 4). The Bathonian sequence northwest of Limestone Hills in the upper part of the Little Nelchina River Valley contains some highly fossiliferous siltstone similar to that in the Boulder Creek area, as just described, but differs by consisting mostly of gray medium- to thick-bedded sandstone and by containing pebbles and cobbles in its upper part. The sequence exposed from 3 to 4 miles farther north on the south side of the Little Oshetna River differs by consisting mostly of thick-bedded sandstone that is interbedded with lenses of conglomerate in its upper part and with coaly and plant-bearing beds in its lower part; it contains very few marine fossils.

On the southern flank of the Wrangell Mountains the Bathonian is represented within the Nizina Mountain Formation, which crops out in the McCarthy C-5 quadrangle (MacKevett, 1969, p. A42-A45; 1971, p. 16, 17, 
in the Wrangell Mountains and Talkeetna Mountains, Alaska

Higher numbers are USGS Mesozoic locality numbers]

\begin{tabular}{|c|c|c|c|c|c|c|c|c|c|c|c|c|c|c|c|c|c|c|c|c|c|c|c|c|c|c|c|c|}
\hline \multicolumn{29}{|c|}{ Talkeetna Mountains } \\
\hline \multicolumn{29}{|c|}{ Unnamed beds equivalent to $B$} \\
\hline \multicolumn{11}{|c|}{ Nelchina area } & \multicolumn{18}{|c|}{ Boulder Creek area } \\
\hline 1213 & 14 & 15 & & & & 16 & & & & & & & & & & 1 & 7 & & & & & & & 18 & 19 & & 20 & \\
\hline 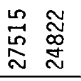 & $\stackrel{\sim}{\underset{\Xi}{\Xi}}$ & $\begin{array}{l}\stackrel{\sim}{\sim} \\
\stackrel{\infty}{N} \\
\stackrel{N}{N}\end{array}$ & 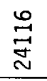 & $\vec{\exists}$ & $\stackrel{\infty}{\underset{\Xi}{\leftrightarrows}}$ & 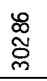 & 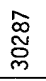 & $\begin{array}{l}\infty \\
\stackrel{\infty}{0} \\
\stackrel{్}{\tilde{~}}\end{array}$ & 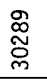 & \&̊. & 志 & $\begin{array}{l}\stackrel{n}{\widetilde{N}} \\
\widetilde{\tilde{~}}\end{array}$ & 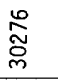 & હิ & $\stackrel{\infty}{\stackrel{\infty}{\widetilde{్}}}$ & ڤ્ & 趸 & 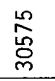 & $\begin{array}{l}\stackrel{\circ}{\circ} \\
\stackrel{\rho}{\circ} \\
\end{array}$ & 총 & $\begin{array}{l}\infty \\
\stackrel{\infty}{\circ} \\
\end{array}$ & 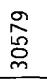 & 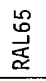 & 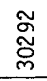 & $\underset{\substack{m \\
\infty}}{\infty}$ & 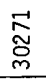 & ָั & 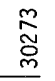 \\
\hline---- & -- & -- & -- & -- & -- & -- & -- & -- & -- & -- & -- & -- & -- & $\overline{-}$ & -- & $\cdots$ & $x$ & -- & -- & -- & $\overline{--}$ & -- & -- & -- & -- & - & -- & $\overline{--}$ \\
\hline -- -- & -- & -- & -- & -- & -- & $x$ & -- & -- & -- & - & -- & -- & -- & -- & -- & -- & -- & -- & $x$ & -- & -- & -- & -- & -- & -- & - & -- &.- \\
\hline---- & -- & -- & -- & $x$ & -- & -- & -- & -- & -- & -- & -- & $x$ & -- & -- & -- & -- & -- & -- & $x$ & $x$ & $x$ & -- & -- & -- & -- & -- & -- & -- \\
\hline -- -- & -- & -- & -- & -- & -- & -- & -- & -- & -- & -- & -- & -- & -- & -- & -- & -- & -- & -- & -- & - & -- & $\hat{A}$ & -- & -- & -- & -- & -- & - \\
\hline -- -- & -- & -- & $x$ & -- & -- & -- & -- & -- & -- & - & -- & -- &.- & -- & -- & -- & -- & -- & -- & -- & -. & -- & -- & -. & -- & -- & -- & - \\
\hline -- -- & -- & -- & -- & -- & -- & -- & -- & -- & -- & -- & -- & -- & -- & $x$ & -- & -- & -- & -- & $x$ & $x$ & -- & -- & -- & -- & -- & -- & -- & -- \\
\hline -- - & -- & -- & -- & -- & -- & -- & -- & -- & -- & -- & -- & -- & -- & -- & -- & -- & -- & -- & -- & -- & -- & -- & -- & -- & -- & -- & -- & - \\
\hline $\begin{array}{lll}x & --\end{array}$ & $x$ & -- & $x$ & $x$ & -- & $x$ & $x$ & $x$ & $x$ & $x$ & -- & -- & $x$ & $x$ & $x$ & -- & - & $x$ & $x$ & $x$ & $x$ & $x$ & -- & -- & $x$ & $x$ & -- & $x$ \\
\hline$--x$ & -- & $x$ & -- & -- & $x$ & - & -- & -- & -- & -- & -- & -- & -- & -- & -- & $x$ & -- & -- & -- & -- & -- & -- & -- & $x$ & -- & -- & -- & - \\
\hline & -- & -- & -- & -- & -- & -- & -- & -- & -- & -- & -- & -- & -- & -- & -- & -. & - & -- & - & -- & -- & -- & -- & -- & -- & -- & -- & - \\
\hline -- -- & -- & -- & - & -. & - & -- & - & - & -- & -- & -- & -- & -- & -- & -- & -- & -- & -- & -- & -- & -- & -- & -- & -- & -- & -- & -- & -- \\
\hline -- -- & -- & -- & -- & -- & -- & -- & - & -- & $\cdots$ & -- & -- & $x$ & -- & -- & - & -- & -- & -- & -- & -- & -- & -- & -- & -- & -- & - & - &.- \\
\hline -- -- & -- & -- & $x$ & $x$ & $x$ & -- & -- & -- & -- & -- & -- & -- & -. & -- & -. & -- & -. & -- & -- & -- & -- & -- & -- & -- & -- & -- & -- & -- \\
\hline -- -- & -- & -- & -- & -- & -- & -- & -- & -- & -- & -- & -- & $x$ & -- & -- & -- & -- & -- & -- & -- & -- & -- & -- & -- & -- & -- & -- & -- & -- \\
\hline -- -- & -- & -- & $--\cdot$ & -- & -- & -- & -- & -- & -- & -- & -- & -- & -- & -- & -- & -- & -- & -- & -- & -- & -- & -- & -- & -- & -. & -- & -- &.- \\
\hline -- -- & -- & -- & -- & -- & -- & -- & -- & $x$ & -- & $x$ & -- & -- & -- & -- & -- & -- & -- & - & -- & -- & -- & -- & -- & -- & -- & -- & -- & $\cdots$ \\
\hline-- & - & -- & $x$ & -- & -- & -- & -- & -- & -- & $\cdots$ & -- & -- & -- & -- & -- & -- & -- & -- & -- & -- & -- & -- & -- & -- & -- & -- & -- & - \\
\hline -- -- & -- & -- & -- & -- & -- & -- & -- & -- & -- & -- & $x$ & -- & -- & -- & -- & - & $x$ & -- & -- & -- & $x$ & -- & -- & -- & -- & -- & -- & - \\
\hline -- -- & -- & -- & -- & - & -- & -- & -- & -- & -- & -- & -- & -- & -- & $\mathrm{x}$ & -- & -- & -- & -- & -- & -- & -- & -- & -- & -- & -- & -- & -- & -- \\
\hline -- -- & -- & -- & -- & -- & -- & -- & -- & -- & -- & -. & -- & -- & -- & -- & -- & -- & -- & -- & $x$ & $x$ & -- & -- & -- & -- & -- & -- & $x$ & - \\
\hline -- -- & -- & -- & -- & $x$ & -- & -- & -- & -- & -- & -- & -- & -- & $x$ & -- & -- & -. & - & -- & -- & -- & -- & -- & -- & -- & -- & -- & $x$ & - \\
\hline -- -- & -- & -- & -- & -- & -- & -- & -- & -- & -- & -- & -- & -- & -- & -- & -- & -- & -- & -- & -- & -- & -- & -- & -- & -- & -- & -- & -- & -- \\
\hline -- -- & -- & -- & $x$ & -- & -- & -- & -- & -- & -- & -- & -- & -- & -- & $x$ & -- & -- & $\mathrm{x}$ & -- & -- & -- & $x$ & -- & -- & -- & -- & - & -- & -- \\
\hline -- -- & -- & -- & -- & -- & -- & -- & -- & -- & -- & -- & -- & -- & -- & -- & -- & -- & -- & -- & -- & -- & -- & -- & $x$ & -- & -- & -- & -- & -- \\
\hline - - & -- & -- & -- & -- & -- & & - & -- & -. & -- & -- & - & -- & -- & -- & -- & -- & -- & -- & -- & -- & & -- & -- & -- & -- & -- & \\
\hline
\end{tabular}

28). That formation attains a maximum thickness of 1,500 feet, at most places is much thinner, and locally pinches out. It is overlain disconformably by the Root Glacier Formation of late Oxfordian to middle Tithonian Age or by younger rocks. It is underlain disconformably by the Lubbe Creek Formation of Pliensbachian Age or by the upper member of the McCarthy Formation of earliest Jurassic Age (MacKevett, 1969, p. A44, A46; 1970; Imlay and Detterman, 1973, fig. 11A). It consists mostly of hard dark-greenish-gray fine to very fine grained medium-bedded graywacke but includes some limy shale and some shaly partings.

\section{BATHONIAN AMMONITE SUCCESSION}

\section{WEST OF COOK INLET}

The stratigraphic positions of many fossil collections within the Bowser Formation between Iniskin Bay and Tuxedni Bay are described herein in table 4 and are depicted in part on columnar sections (fig. 2). These data permit fairly accurate determinations of the stratigraphic ranges of many species relative to the top and bottom of the formation and to other species or genera (fig. 5). 
TABLE 3.-Geographic distribution of Bethonian ammonites [Numbers 21-58 are keyed to locality numbers in figures

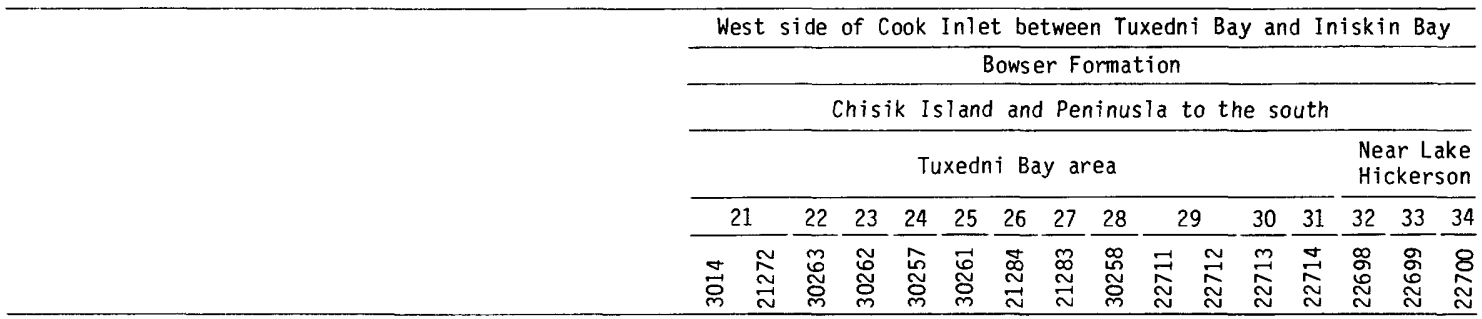

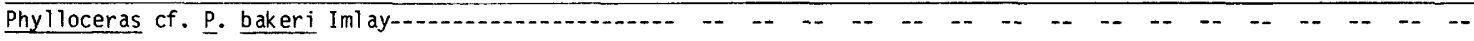

(Macrophylloceras) grossicostatum Imlay-...-....

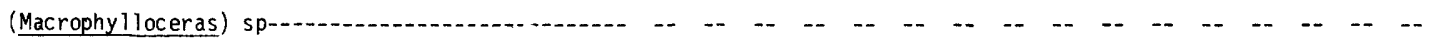

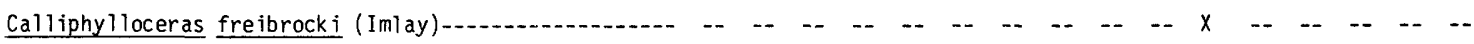
Lytoceras sp--.---1.---.--

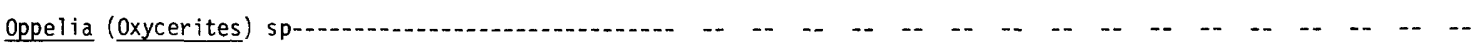

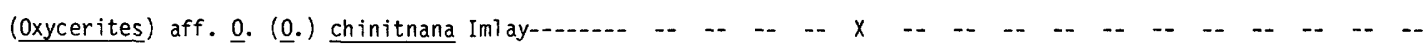

(Liroxyites) cf. $\underline{0}$. (ㄴ.) kellumi Imlay-.......-

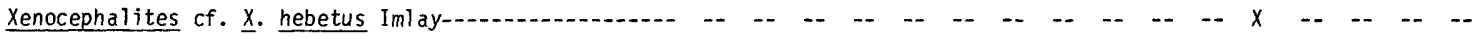

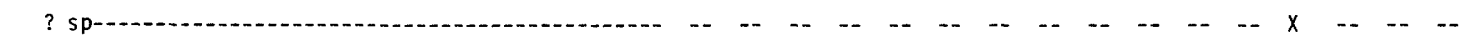

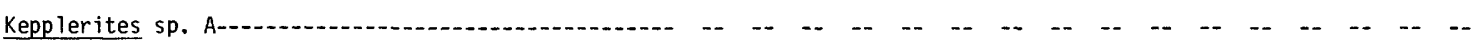
Sp. B-_._. sp. C? sp-10.-. Cranocephalites costidensus $I m l$ ay--...............

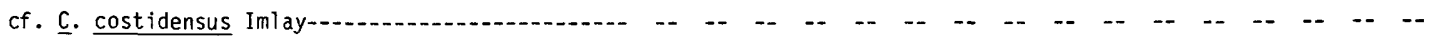

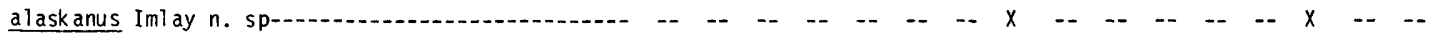

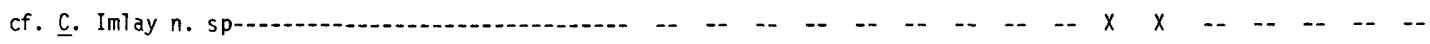

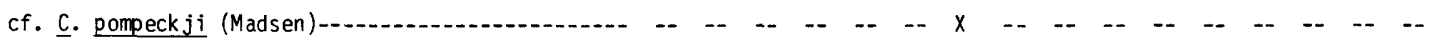
globosus Imlay---1-10.-sp. A-1-1 sp. B sp. juv-1-10 ? Sp--10

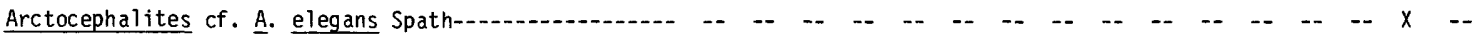
Tuxednites alticostatus $($ Imlay)--.-1.-.-. cf. I. alticostatus $I m l$ ay--...-. ? sp-Chinitnites parviformis Iml ay--.-1.-.-. sp-_......... Iniskinites intermedius (Iml ay) cf. I. intermedius (Imlay) -................... sp. juv. cf. I. magniformis (Iml ay)-C.-.-.-. Parareineckeia hickersonensis Imlay--.-1.-....-.-.-.-.nelchinens is Iml ay $n$. sp--10.--

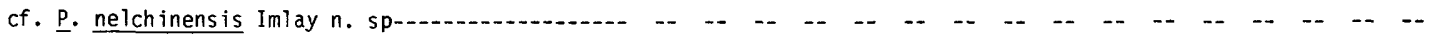

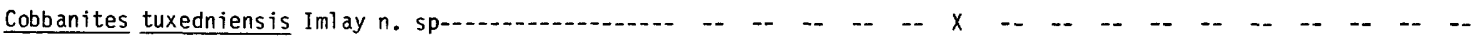
sp--..-.-. Siemeradzkia cf. $\underline{\underline{S}}$. aurigera (Oppel)-............ 
between Tuxedni Bay and Iniskin Bay west of Cook Inlet, Alaska

10 and 11 . Higher numbers are USGS Mesozoic locality numbers]

\begin{tabular}{|c|c|c|c|c|c|c|c|c|c|c|c|c|c|c|c|c|c|c|c|c|c|c|c|c|c|c|c|c|}
\hline \multicolumn{29}{|c|}{ Bowser Bay Formation--Continued } \\
\hline \multicolumn{29}{|c|}{ Iniskin Peninsula } \\
\hline \multicolumn{4}{|c|}{$\begin{array}{c}\text { Chinitna Bay } \\
\text { area }\end{array}$} & \multicolumn{6}{|c|}{$\begin{array}{l}\text { Tonnie Creek and } \\
\text { Brown Creek }\end{array}$} & \multicolumn{11}{|c|}{ Bowser Creek } & \multicolumn{8}{|c|}{ Iniskin Bay area } \\
\hline 35 & & 3 & & 37. & & 39 & & 0 & 41 & 42 & 43 & & & & & & 45 & & 50 & & 5 & & & 54 & & & & \\
\hline 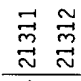 & & $\begin{array}{l}\stackrel{\infty}{0} \\
\stackrel{\vec{\sim}}{\sim}\end{array}$ & 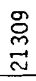 & $\underset{\vec{\sim}}{\stackrel{\vec{\sim}}{\mathbf{N}}}$ & $\overrightarrow{\widetilde{d}}$ & 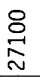 & ¿̊. & $\begin{array}{l}\stackrel{0}{0} \\
\text { ठ্ల }\end{array}$ & $\stackrel{\text { 엄 }}{\stackrel{N}{N}}$ & $\begin{array}{l}\infty \\
\stackrel{O}{\Xi} \\
\Xi\end{array}$ & 苂 & 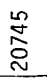 & 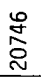 & $\underset{\Xi}{\tilde{\Xi}}$ & 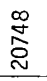 & $\underset{\text { స్లి }}{\stackrel{\text { N }}{N}}$ & $\begin{array}{l}\vec{n} \\
\hat{0} \\
\stackrel{N}{N}\end{array}$ & $\begin{array}{l}\tilde{N} \\
\stackrel{\sim}{\sim}\end{array}$ & $\underset{\sim}{\stackrel{2}{*}}$ & $\begin{array}{l}\text { \& } \\
\stackrel{\sim}{\sim}\end{array}$ & 慶 & 怘 & 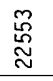 & 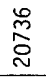 & 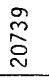 & $\stackrel{\infty}{\tilde{o}_{\tilde{m}}}$ & 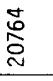 & $\underset{\mathbb{Z}}{\stackrel{\Xi}{\sim}}$ \\
\hline$\overline{x \quad x}$ & -- & -- & -- & -- & -- & -- & -- & -- & -- & -- & -- & -- & - & -- & -- & -- & -- & -- & -- & -- & -- & -- & -- & -- & -- & -- & -- & -- \\
\hline$x \quad x$ & $x$ & -- & -- & -- & -- & -- & -- & -- & -- & -- & -- & -- & $\ldots$ & - & -- & -- & -- & -- & -- & -- & -- & -- & -- & -- & -- & -- & -- & -- \\
\hline-- & -- & -- & -- & 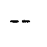 & -- & -- & -- & -- & -- & -- & -- & -- & -- & -- & -- & -- & -- & -- & -- & -- & -- & -- & -- & -- & - & -- & -- & - \\
\hline$x \quad x$ & -- & -- & -- & -- & -- & -- & -- & -- & -- & -- & -- & -- & -- & -- & -- & -- & -- & -- & -- & -- & -- & -- & -- & - & -- & -- & -- & - \\
\hline--- & -- & -- & -- & -- & - & -- & -- & - & -- & -- & -- & -- & -- & -- & -- & -- & -- & -- & -- & -- & -- & -- & -- & -- & $x$ & -- & - & - \\
\hline---- & -- & -- & -- & -- & -- & -- & -- & - & -- & -- & -- & -- & -- & -- & -- & -- & -- & -- & -- & -- & -- & & -- & -- & -- & -- & -- & - \\
\hline---- & -- & -- & -- & -- & -- & -- & -- & -- & -- & -- & -- & -- & -- & -- & -- & -- & -- & -- & -- & -- & -- & -- & -- & -- & -- & -- & -- & -- \\
\hline---- & -- & -- & -- & - & -- & -- & -- & -- & -- & -- & -- & -- & -- & -- & -- & -- & -- & -- & -- & -- & -- & -- & -- & -. & -- & -- & -- & + \\
\hline$--x$ & $x$ & -- & -- & -- & -- & -- & -- & -- & -- & -- & -- & -- & -- & -- & -- & -- & -- & -- & -- & -- & -- & -- & -- & -- & -- & -- & $\cdots$ & -1 \\
\hline---- & -- & -- & -- & -- & -- & -- & -- & -- & -- & -- & -- & -- & -- & -- & -- & -- & -- & -- & -- & -- & -- & -- & -- & -- & -- & -- & -- & - \\
\hline -.. - & -- & - & -- & $x$ & -- & -- & -- & -- & -- & -- & -- & -- & -- & - & -- & -- & -- & -- & -- & -. & -- & -- & -- & -- & -- & -- & -- & - \\
\hline -- -- & -- & -- & -- & - & -- & -- & -- & -- & -- & -- & -- & -- & -- & -- & -- & -- & -- & -- & -- & $\cdots$ & -- & -- & -- & -- & -- & -- & -- & - \\
\hline -- - & -- & -- & -- & -- & -- & -- & -- & -- & -- & -- & -- & -- & -- & -- & -- & -- & -- & -- & -- & -- & -- & -- & -- & -- & -- & -- & -- & - \\
\hline -- -- & -- & -- & -- & -- & -- & -- & -- & -- & $\mathrm{n}$ & -- & -- & -- & -- & -- & -- & -- & -- & -- & -- & . & - & $\ldots$ & 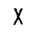 & -- & -- & - & -- & - \\
\hline--- & -- & -- & -- & -- & -- & -- & -- & -- & - & -- & ג & -- & -- & -- & -- & -- & -- & -- & -- & -- & -- & -- & -- & -- & -- & -- & $\cdots$ & - \\
\hline$\cdots$ & -- & -- & -- & -- & -- & -- & -- & -- & -- & -- & $x$ & -- & -- & -- & -- & -- & -- & -- & -- & -- & -- & -- & $\cdots$ & $x$ & -- & -- & -- & - \\
\hline -. - - & -- & 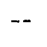 & - & & -- & 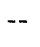 & -- & -- & -- & -- & -- & -- & -- & -- & -- & -- & -- & -- & -- & 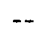 & -- & -- & -- & -- & -- & -- & -- & 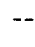 \\
\hline -- -- & -- & -- & $x$ & -- & - & -- & -- & -- & -- & -- & $x$ & -- & -- & -- & -- & -- & -- & -- & -- & -- & -- & -- & -- & -- & -- & -- & -- & - \\
\hline 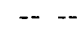 & -- & -- & -- & -- & -- & -- & -- & -- & -- & -- & -- & -- & -- & -- & -- & -- & -- & -- & - & $\ldots$ & -- & -- & -- & -- & -- & -- & -- & - \\
\hline -- -- & 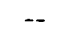 & 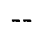 & & 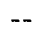 & -- & 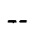 & -- & -- & -- & -- & -- & -- & -- & -- & -- & -- & A & -- & -- & -- & -- & -- & -- & -- & -- & -- & - & - \\
\hline -- -- & $x$ & -- & -- & -- & -- & -- & -- & -- & - & -- & -- & -- & -- & -- & -- & -- & -- & -- & -- & -- & -- & -- & -- & -- & -- & -- & -- & - \\
\hline -- -. & - & -- & -. & -- & -- & -- & -- & -- & -- & -- & -. & 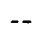 & 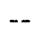 & -. & -- & -- & -- & -- & -- & . & -- & $\ldots$ & -- & -- & -- & -- & -- & - \\
\hline -- -- & -- & $\lambda$ & -- & . & - & - & -- & -- & -- & -- & -- & & -- & -- & -- & -- & -- & -- & -- & $\because$ & -- & -- & -- & $\cdots$ & -- & $x$ & -- & - \\
\hline -- -- & -- & -- & -- & -- & -- & $x$ & -- & -- & -- & -- & -- & -- & - & -- & -- & -- & -- & -- & $x$ & -- & -- & -- & -- & -- & -- & -- & -- & - \\
\hline -- -- & -- & -- & -- & -- & -- & -- & -- & -- & -- & -- & -- & - & 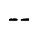 & -- & -- & -- & -- & - & -- & 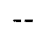 & -- & 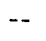 & -- & -- & -- & -- & -- & - \\
\hline -- -- & - & -- & -- & -- & $x$ & -- & -- & -- & -- & -- & -- & -- & & -- & -- & -- & -- & $x$ & -- & -- & -- & -- & -- & -- & -- & $x$ & -- & - \\
\hline -- -- & -- & -- & -- & -- & -- & -- & - & -- & -- & -- & -- & -- & -- & -- & - & -- & -- & -- & -- & --_ & -- & -- & -- & -- & -- & -- & -- & $\cdots$ \\
\hline -- -. & -- & -- & -- & -- & -- & 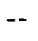 & $x$ & & . & 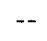 & -- & -- & . & -- & -- & -- & -- & -. & -. & & -- & -- & -- & -. & -- & -- & -- & - \\
\hline -- -- & $x$ & -- & -- & -- & -- & -- & -- & -- & -- & $x$ & -- & -- & -- & 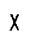 & -- & -- & -- & -- & -- & -- & -- & -- & -- & -- & -- & -- & -- & - \\
\hline -- -- & -- & -- & -- & -- & -- & 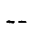 & -- & -- & . & -- & $\cdots$ & -- & 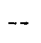 & -- & $x$ & & $\cdots$ & -- & -- & . & -- & 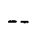 & -- & -- & -- & -- & -- & $x$ \\
\hline -- -- & -- & $\cdots$ & -. & -- & -- & -- & -- & -- & $\ldots$ & -- & -- & - & -- & -- & -- & -- & -- & -- & -- & $\because$ & -- & -- & -- & -- & -- & -- & -- & - \\
\hline$--x$ & -- & -- & -- & -- & 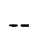 & -- & -. & - & -- & -- & -- & -- & -- & -- & -. & -- & -. & -- & -- & -- & -- & -- & -- & -- & -- & $x$ & $x$ & $\ldots$ \\
\hline-- & -- & -- & -- & -- & -- & - & -- & -- & -- & -- & -- & -- & $\cdots$ & -- & -- & -- & -- & -- & -- & -- & $x$ & -- & -- & -- & -- & -- & -- & - \\
\hline -- -- & -- & -- & -- & -- & -- & -. & -- & -- & -- & -- & -- & - & & -- & 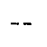 & -- & -- & -- & -- & . & -- & $\cdots$ & -- & -- & -- & -- & -- & - \\
\hline-- & -- & -- & -- & -- & -- & 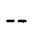 & -- & -- & -- & $-\cdot$ & -- & -- & $\cdots$ & -- & -- & -- & -- & -- & -- & - & -- & -- & -- & -- & -- & $x$ & -- & - \\
\hline -- - & -- & -- & -- & -- & -- & & -- & - & -- & -- & - & & & -- & - & & -- & -- & -- & 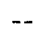 & -- & -- & -- & -- & -- & -- & -- & - \\
\hline -- -- & -- & -- & -- & -- & 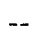 & 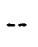 & -- & -- & $\cdots$ & -- & -- & -- & -1 & -- & -- & -- & -- & -- & -- & -- & -- & - & -- & -- & -- & -- & -- & $\ldots$ \\
\hline & -- & $\cdots$ & - & -- & -- & & -- & -- & -- & -- & -. & - & & -- & -- & & - & -- & - & & -- & -- & - & -- & -- & -. & $x$ & - \\
\hline -- & & -- & - & -- & - & & -- & 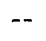 & 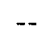 & & & & & & . & & - & - & -- & & -- & 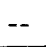 & -- & -- & -- & -- & -- & \\
\hline
\end{tabular}


NORTH

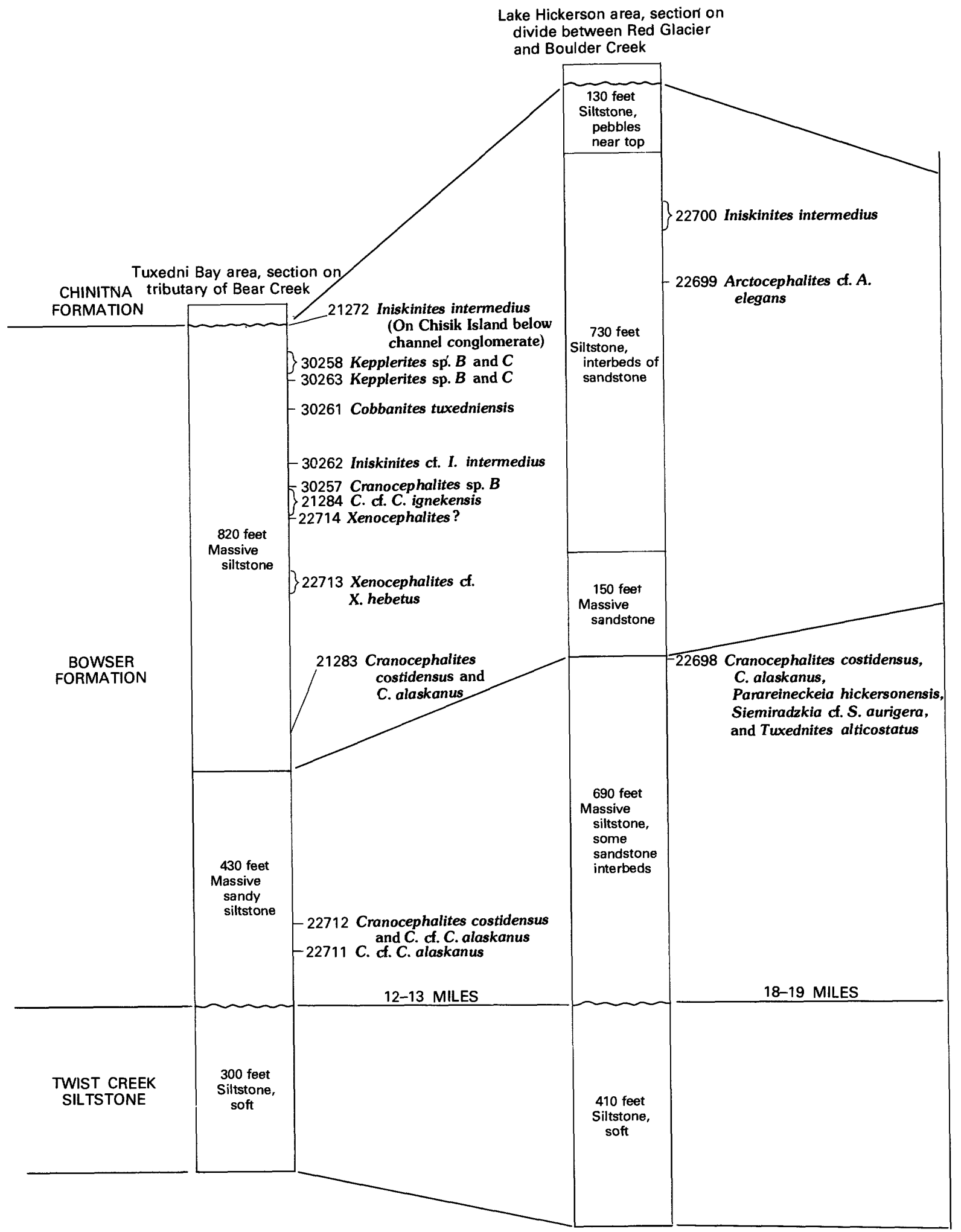

FIGURE 2. Stratigraphic positions of some Bathonian ammonite localities in the Bowser Formation west of Cook Inlet between Tuxedni Bay and Iniskin Bay. Data from Detterman and Hartsock, 1966, p. 37-40, pl. 5. Approximate locations of sections are shown in figures 10 and 11. 
SOUTH

Area of Tonnie Creek, Edelman Creek, and upper part Bowser Creek, section on Tonnie Creek

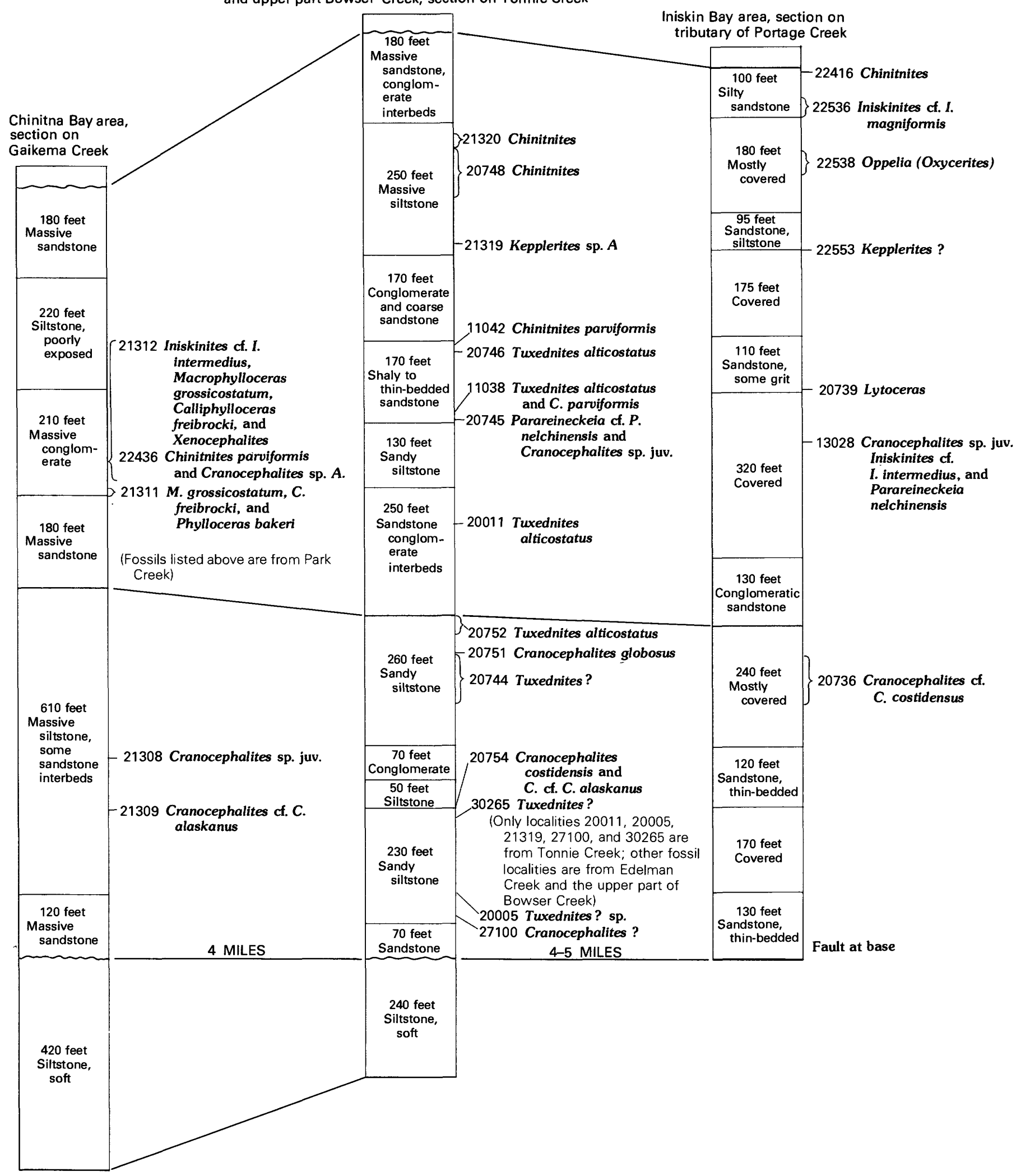

FIGURE 2.-Continued. 


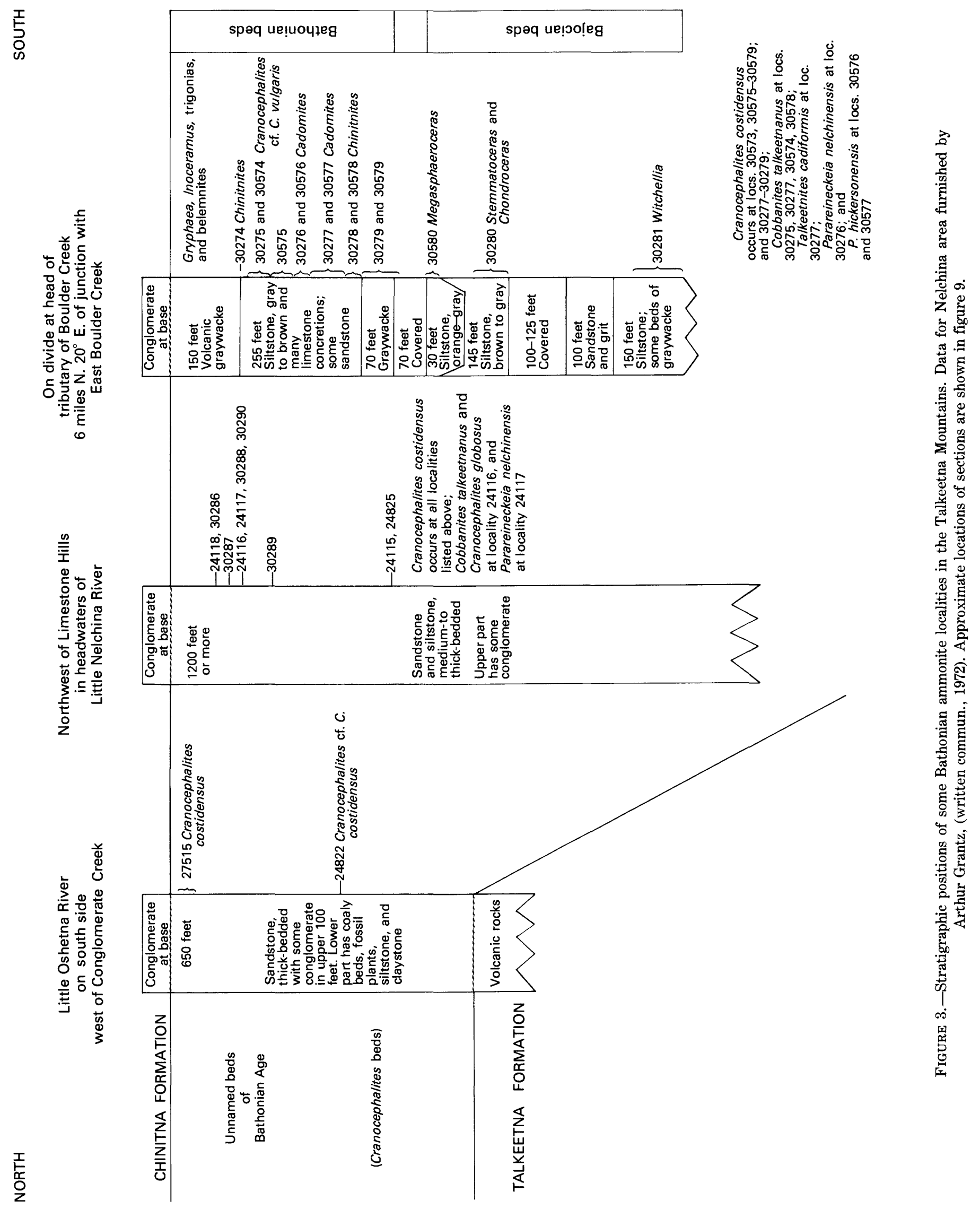




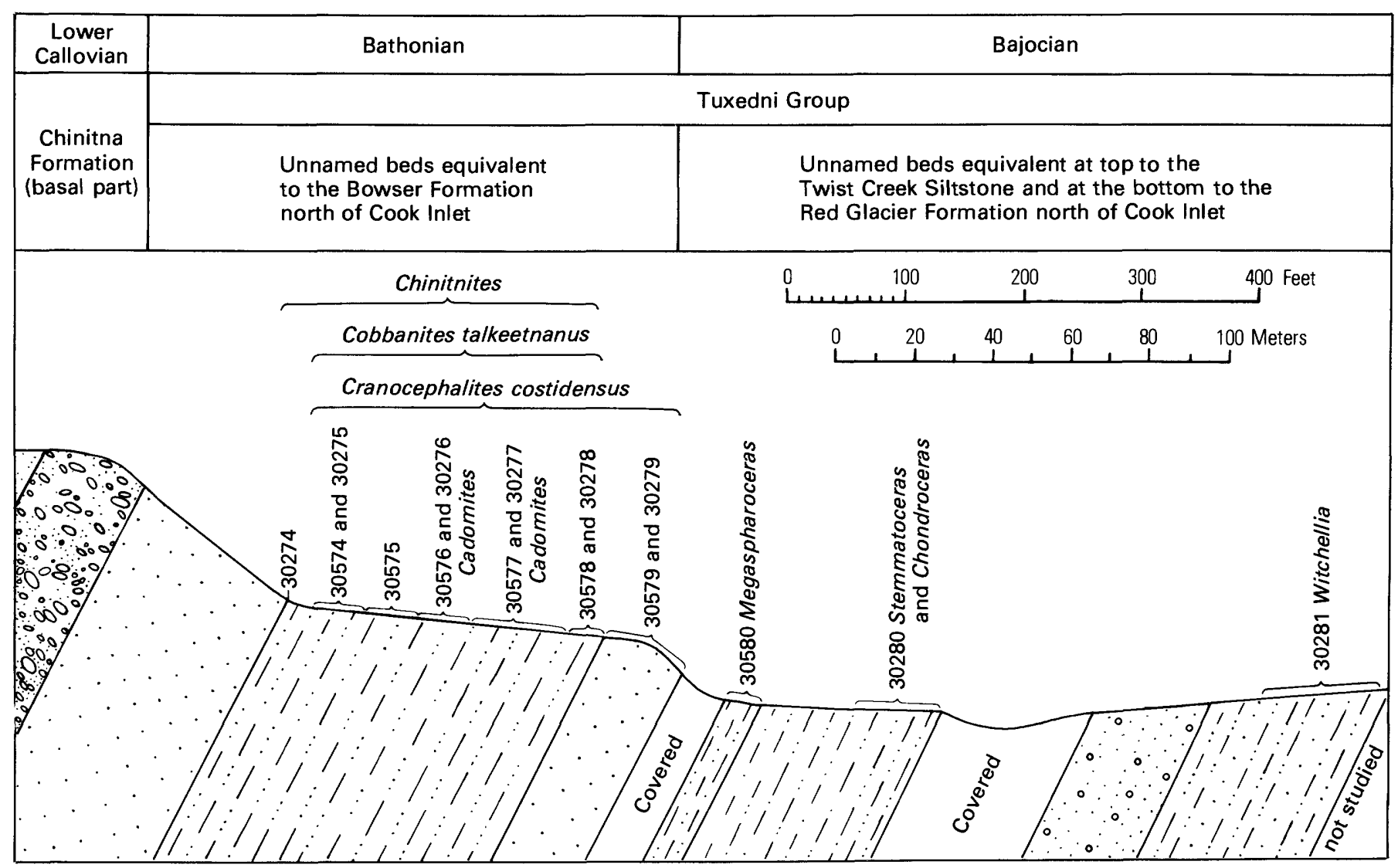

FIGURE 4.-Partial Middle Jurassic sequence including Bathonian beds exposed on a northwest-trending divide at head of a tributary of Boulder Creek near center of NW1/4SE1/4 sec. 26, T. 22 N., R. 7 E., Anchorage D-3 quadrangle, Talkeetna Mountains, Alaska.

These ranges show that the lower two-fifths, or lower $500-700$ feet, of the formation is characterized by an abundance of Cranocephalites costidensus (Imlay). The overlying $300-450$ feet of beds contain coarser ribbed species of Cranocephalites, which are associated with the lowermost occurrences of Xenocephalites and of Chinitnites parviformis (Imlay). The next higher 300580 feet of beds at the top of the formation are characterized by species of Iniskinites including I. intermedius (Imlay) and some specimens of Cobbanites, Chinitnites, Arctocephalites, and Kepplerites. Cobbanites occurs about 150 feet below the top of the formation near Tuxedni Bay. (See figs. 2, 5.) Chinitnites parviformis (Imlay) and Chinitnites sp. range upward into the lower part of the overlying Chinitna Formation (Imlay, 1975, p. 23). Arctocephalites near Lake Hickerson occurs 360-380 feet below the top of the formation and 170-190 feet below Iniskinites intermedius (Imlay). Kepplerites occurs at two levels from 50 to 100 feet below the top of the formation near Tuxedni Bay, 420 feet below the top at Tonnie Creek, and is probably present 360 feet below the top at Iniskin Bay. These occurrences of Kepplerites are clearly within the upper part of the range of Iniskinites.

\section{TALKEETNA MOUNTAINS}

The stratigraphic occurrences of the Bathonian fossil collections within certain unnamed beds in the Talkeetna Mountains are described herein in table 4 and are depicted in columnar sections (fig. 3). This information, at least for the Boulder Creek area, makes possible the determination of the stratigraphic ranges of some species relative to each other and to the top and bottom of the lithologic unit in which they occur (fig. 6).

All the ammonite-bearing beds in the Nelchina area and most of them in the Boulder Creek area are characterized by an abundance of Cranocephalites costidensus and are equivalent to only the lower 500-700 feet of the Bowser Formation west of Cook Inlet. Also, the uppermost 65 feet of the siltstone sequence in the Boulder Creek area contain species of Cranocephalites that are similar to $C$. vulgaris Spath and to $C$. cf. $C$. ignekensis Imlay (USGS Mesozoic loc. 30275) and probably correlate with beds in the middle part of the Bowser Formation that contain similar coarsely ribbed forms of Cranocephalites (for example, USGS Mesozoic loc. 21284). Nonetheless, the absence of Iniskinites in the Talkeetna 


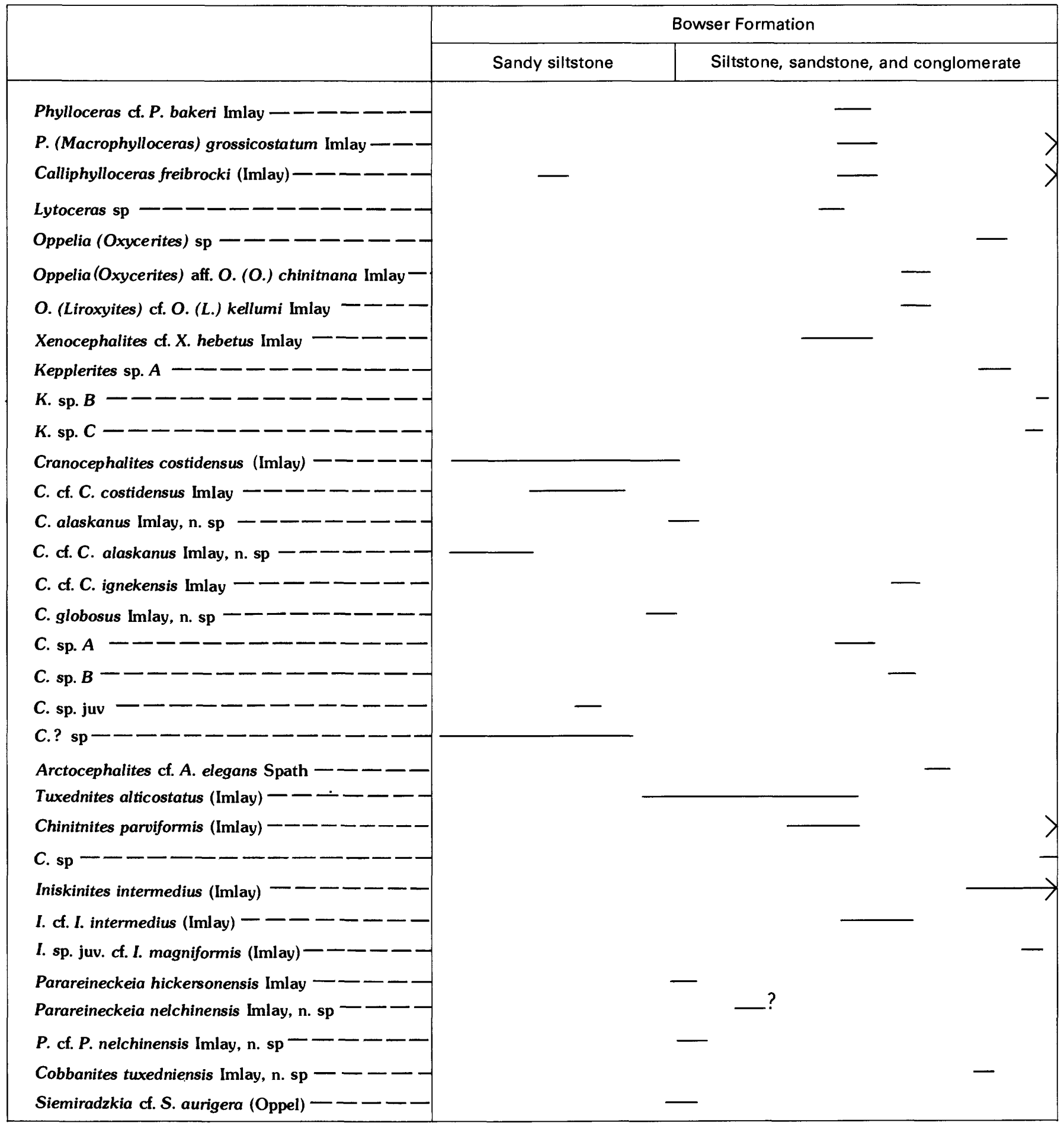

FIgURE 5. - Stratigraphic ranges of Bathonian ammonites in the Bowser Formation west of Cook Inlet, Alaska.

Mountains suggests that marine beds equivalent to the upper part of the Bowser Formation are either absent in those mountains or are represented in the Boulder Creek area by the upper 150 feet of volcanic graywacke that has not furnished any ammonites.

\section{WRANGELL MOUNTAINS}

The stratigraphic positions of many of the fossil collections within the Nizina Mountain Formation are not well known (table 4). Ammonites of probable early Bathonian 


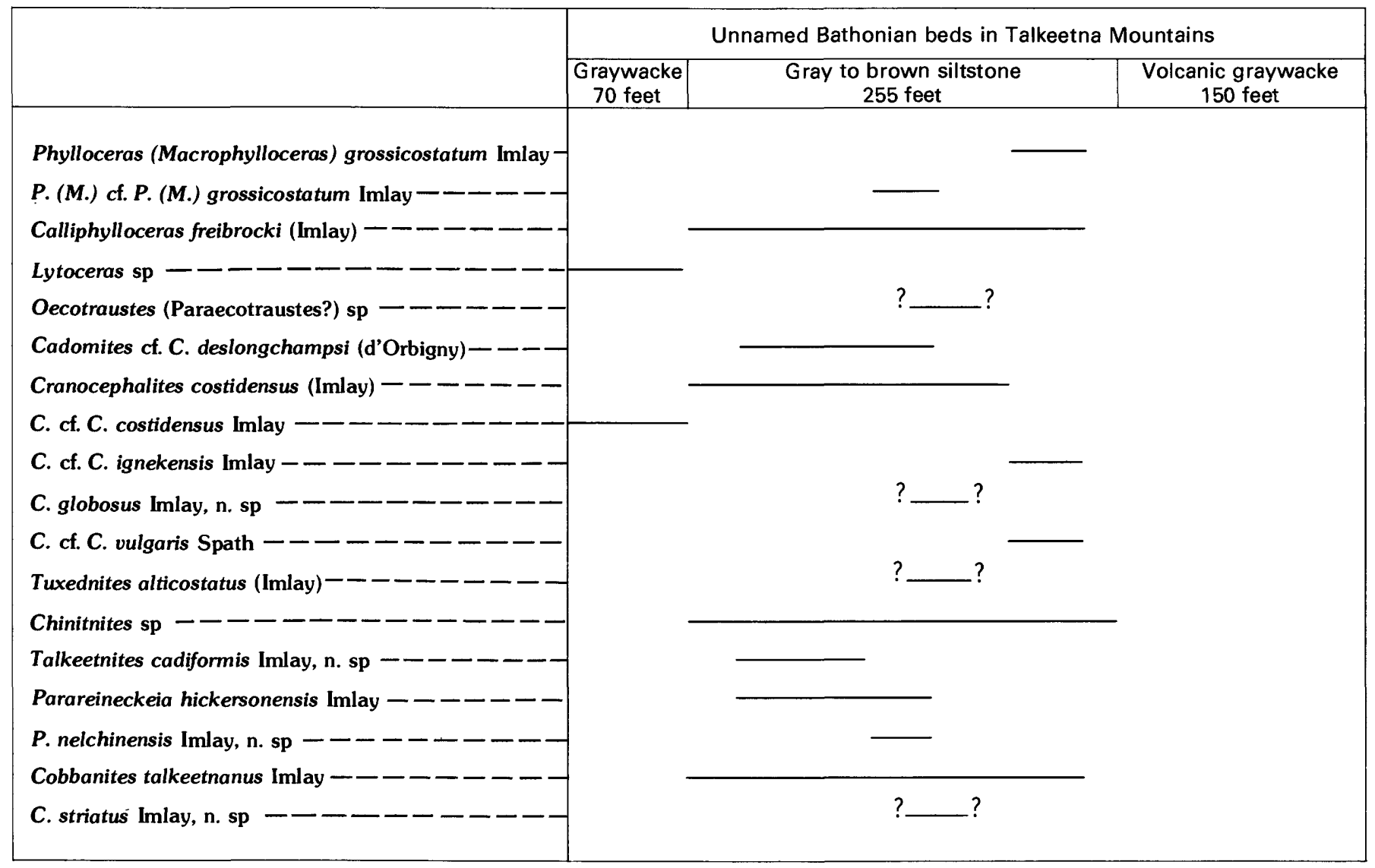

FIGURE 6.-Stratigraphic ranges of Bathonian ammonites in unnamed beds in the Talkeetna Mountains, Alaska. Ranges bounded by question marks indicate fossil occurrences in the Nelchina area. Other ranges indicate fossil occurrences in the Boulder Creek area.

Age have been obtained, however, from at least the lower 500 feet of that formation (table 3) and represent the same species as are associated with Cranocephalites costidensus in the Talkeetna Mountains and west of Cook Inlet. No faunal evidence for younger faunules of Bathonian or Callovian Age has yet been found in the Wrangell Mountains. The fact that one fossil collection, obtained mostly as float (USGS Mesozoic loc. 28682), includes specimens of Teloceras, Normannites, and Chondroceras (Imlay and Detterman, 1973, p. 24) shows that, at least locally, the formation is basally of late middle or early late Bajocian Age.

\section{AGES AND CORRELATIONS}

The lowermost beds of Bathonian, or probable Bathonian, Age in southern Alaska are characterized by Cranocephalites costidensus (Imlay) and are dated as early Bathonian for the following reasons: (1) They rest unconformably on beds of early late Bajocian Age or of older Jurassic Age (Detterman and Hartsock, 1966, p. 35, 40; Imlay and Detterman, 1973, p. 11, 14, 15; Grantz, 1961, written commun.). (2) They occur west of Cook In- let in the basal part of an ammonite sequence that is similar to Bathonian ammonite sequences in northern Alaska, northern Canada, and East Greenland (fig. 7), except for the absence of Arcticoceras (Imlay, 1975, p. 14). (3) They contain the ammonite Cadomites, which ranges from uppermost Bajocian through most of the Bathonian (Hahn, 1971, p. 110), and Siemeradzkia (Imlay, 1962a, p. C20 , pl. 2, figs. 9, 10), which is known only from the Bathonian (Hahn, 1969, p. 39). (4) They contain several specimens of Cadomites similar to $C$. deslongchampsi (d'Orbigny), which in Europe ranges from the uppermost Bajocian into the lower Bathonian (Sturani, 1964, p. 20). (5) They contain one specimen of Cadomites similar to C. rectelobatus (v. Hauer), which in Europe ranges from the uppermost Bajocian through most of the Bathonian but is most common in the lower Bathonian (Sturani, 1966, p. 29; Kopik, 1974, p. 21, 22). (6) They underlie beds containing species of Cranocephalites similar to those in the $C$. pompeckji zone of East Greenland that is dated by Callomon (1959, p. 508) as early, but not earliest, Bathonian.

Against this early Bathonian Age assignment of the beds characterized by Cranocephalites costidensus is the 


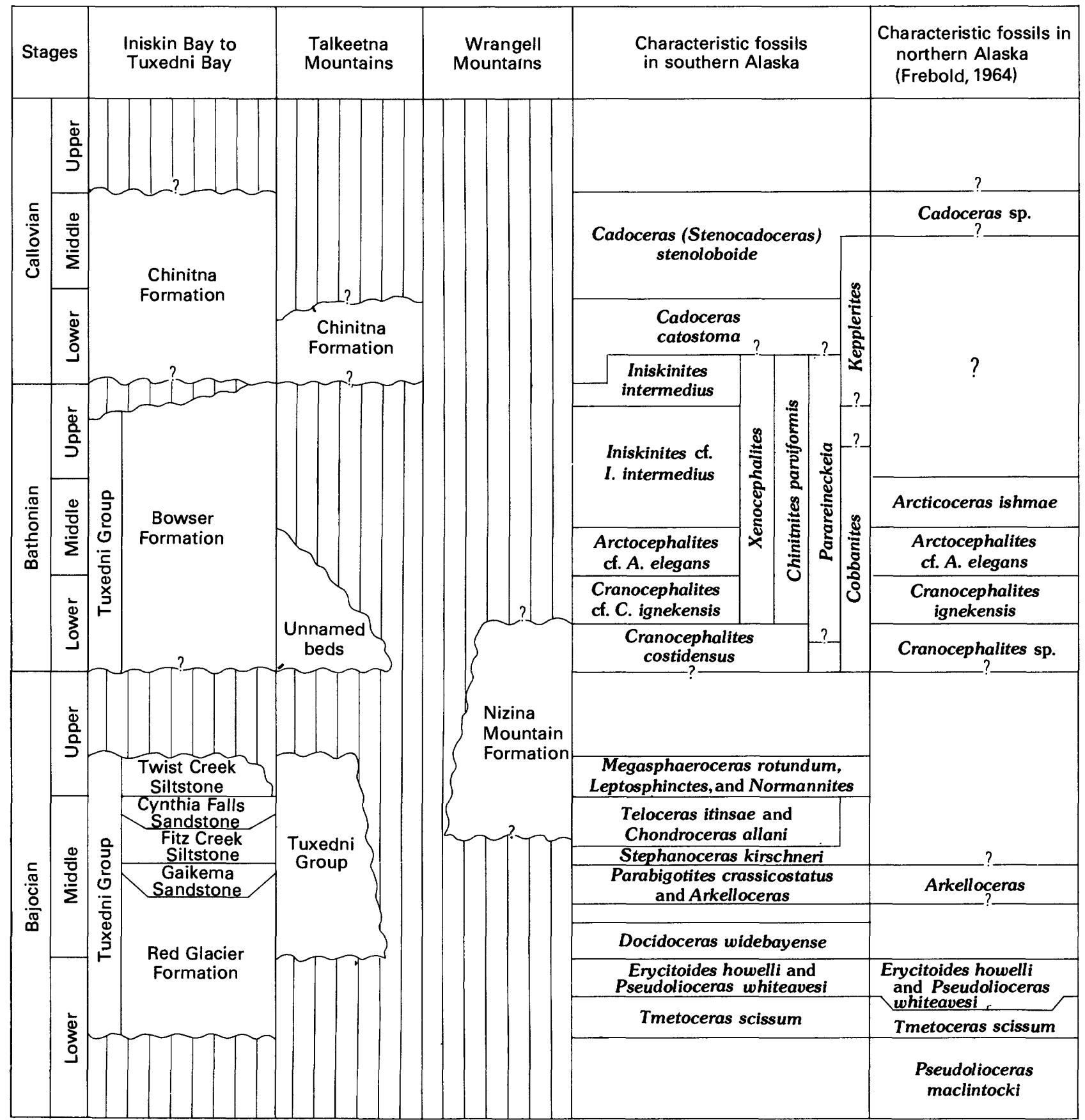

FIGURE 7.-Correlation of Middle Jurassic formations and ammonite faunas in southern Alaska with ammonite faunas of northern Alaska, Greenland, and northwest Europe.

presence of Cobbanites, whose resemblance to Vermisphinctes of the Leptosphinctinae suggests a late Bajocian Age. Against a late Bajocian assignment, however, is an occurrence of Cobbanites, described herein as $C$. tuxedniensis Imlay n. sp., only 150 feet below the top of the Bowser Formation, 50 feet below Kepplerites, 150 200 feet above Cranocephalites cf. C. ignekensis Imlay, and 600 feet above the uppermost occurrence of Cranocephalites costidensus (Imlay). Cobbanites at that stratigraphic position must be considerably younger than $\mathrm{Ba}$ - jocian and probably as young as late middle Bathonian. Cobbanites is not definitely known from higher beds, although some fragmentary ammonites from the basal part of the Chinitna Formation were once so assigned (Imlay, 1962a, p. C-26, C-27). That assignment now seems unreasonable because the ribs on those ammonites, originally described as Procerites by Imlay (1953, p. 102, pl. 53 , figs. 1-3), do not weaken ventrally as on the type species of Cobbanites at a comparable size (Imlay, 1962a, pl. 8). 


\begin{tabular}{|c|c|}
\hline $\begin{array}{l}\text { East Greenland (Donovan, } \\
\text { 1957; Callomon, 1959; } \\
\text { Surlyk and others, 1973) }\end{array}$ & $\begin{array}{c}\text { Standard zones in northwest } \\
\text { Europe (Callomon, 1964; } \\
\text { Torrens, 1965; Gabilly and } \\
\text { others, 1971; Parsons, } 1974\end{array}$ \\
\hline & Quenstedoceras lamberti \\
\hline $\begin{array}{l}\text { Kosmoceras and } \\
\text { Longaeviceras }\end{array}$ & Peltoceras athleta \\
\hline \multirow{2}{*}{$\begin{array}{l}\text { Kosmoceras and } \\
\text { Pseudocadoceras }\end{array}$} & Erymnoceras coronatum \\
\hline & Kosmoceras jason \\
\hline Sigaloceras calloviense & Sigaloceras calloviense \\
\hline Cadoceras n. sp. & \multirow{2}{*}{$\begin{array}{l}\text { Macrocephalites } \\
\text { macrocephalus }\end{array}$} \\
\hline Cadoceras n. sp. & \\
\hline Cadoceras calyx & Clydoniceras discus \\
\hline Cadoceras variabile & Oppelia aspidoides \\
\hline $\begin{array}{l}\text { Arcticoceras } \mathrm{n} . \mathrm{sp} . \\
\text { and Kepplerites }\end{array}$ & Hecticoceras retrocostatum \\
\hline \multirow{2}{*}{ Arcticoceras ishmae } & Morrisiceras morrisi \\
\hline & Tulites subcontractus \\
\hline Arctocephalites arcticus & Gracilisphinctes progracilis \\
\hline Cranocephalites pompeckji & \multirow{2}{*}{ Zigzagiceras zigzag } \\
\hline Cranocephalites indistinctus & \\
\hline \multirow[t]{10}{*}{ Cranocephalites borealis } & Parkinsonia parkinsoni \\
\hline & Garantiana garantiana \\
\hline & Stenoceras subfurcatum \\
\hline & $\begin{array}{c}\text { Stephanoceras } \\
\text { humphriesianum }\end{array}$ \\
\hline & Otoites sauzei \\
\hline & Witchellia laeviuscula \\
\hline & Hyperlioceras discites \\
\hline & Graphoceras concavum \\
\hline & Ludwigia murchisonae \\
\hline & Leioceras opalinum \\
\hline
\end{tabular}

FIGURE 7.-Continued.

Beds characterized by Cranocephalites costidensus (Imlay) are known outside Alaska only in west-central British Columbia and are likewise dated tentatively as early Bathonian (Frebold and Tipper, 1973, p. 11251130) rather than latest Bajocian. As in Alaska, the age evidence is not positive.

The next higher Bathonian beds west of Cook Inlet and in the Talkeetna Mountains of southern Alaska are characterized by Cranocephalites cf. C. vulgaris Spath and $C$. cf. $C$. ignekensis Imlay. These furnish a correlation with beds that in northern Alaska contain $C$. ignekensis Imlay (1976, p. 15, pl. 2, figs. 9, 11, 12), that in northern Canada contain C. vulgaris Spath (Frebold, 1957, p. 8, pl. 7, figs. 1, 2, pl. 8, fig. 1a-c), and that in East Greenland contain $C$. vulgaris Spath and C. pompeckji (Madsen) (Callomon, 1959, p. 508). All these ammonites occur in the upper part of the range of Cranocephalites. The beds in East Greenland that are characterized by $C$. pompeckji are considered to represent the lower Bathonian along with the underlying beds characterized by $C$. indistinctus Callomon (Surlyk and others, 1973 , p. 9). The beds in southern Alaska that contain $C$. cf. $C$. ignekensis and $C$. cf. $C$. vulgaris are associated with the lowermost occurrences of Xenocephalites, Iniskinites, and the species Chinitnites parviformis Imlay, which taxa are unknown from the other areas mentioned and at the present time are of little value in intercontinental correlations.

The overlying Bathonian beds in the upper part of the Bowser Formation west of Cook inlet are in part of middle Bathonian Age, as shown by the presence of one specimen of Arctocephalites of. A. elegans Spath obtained $360-380$ feet below the top of the formation near Lake Hickerson. This ammonite provides a correlation with Arctocephalites beds in northern Alaska (Imlay, 1976 , p. 3-5, 16) and in East Greenland (Callomon, 1959 , p. 508) that are probably of middle Bathonian Age.

The uppermost beds in the Bowser Formation are tentatively assigned a late Bathonian Age, because they contain Kepplerites but no Cadoceras, a genus that occurs in abundance with Kepplerites in the basal part of the overlying Chinitna Formation. A similar faunal relationship occurs in East Greenland, where Kepplerites appears first in the upper part of the range of Arcticoceras, whereas Cadoceras appears first in the overlying beds (zone of Cadoceras variabile) (Callomon and others, 1972, p. 18).

If this dating of the uppermost part of the Bowser Formation is correct and if the Bathonian-Callovian boundary in East Greenland has been correctly chosen (Callomon and others, 1972 , p. 18), then the uppermost Bathonian zones of Cadoceras variabile and $C$. calyx in Greenland have not been identified faunally in southern Alaska. Those zones could be represented in southern Alaska by an unconformity that is well developed at the base of the Chinitna Formation in the Talkeetna Mountains (Grantz, 1960a, b; 1965; written commun., 1972) and on the west side of Cook Inlet between Tuxedni Bay and Iniskin Bay and is possibly represented in the Iniskin Peninsula by a sharp contact between the Bowser and Chinitna Formations (Detterman and Hartsock, 1966, p. 40, 42, pl. 5). Those zones could also be represented by the basal beds of the Chinitna Formation west of Cook Inlet, as discussed elsewhere (Imlay, 1975, p. 14). 
In summation, the beds containing Cranocephalites costidensus (Imlay) are either earliest Bathonian or latest Bajocian Age or both. An early Bathonian Age is favored by the fact that they rest unconformably on beds of early Bajocian Age, by the presence of an ammonite that probably represents Siemeradskia, and by the presence of a species of Cadomites similar to $C$. rectolobatus (v. Hauer). The overlying beds containing Cranocephalites are dated as probably late early Bathonian because they contain species of that genus that are similar to species in the C. pompeckji zone in East Greenland. Somewhat higher beds that contain Arctocephalites are dated as middle Bathonian by comparison with the faunal sequence in East Greenland. Still higher beds in southern Alaska that contain Kepplerites but no Cadoceras are probably of late Bathonian Age by comparison with East Greenland. The very latest Bathonian in southern Alaska could be represented by an unconformity between the Bowser and Chinitna Formations or by the basal beds of the Chinitna Formation that are characterized by Iniskinites intermedius (Imlay).

\section{AMMONITE FAUNAL SETTING}

The Bathonian ammonite genera found in southern Alaska represent a mixed assemblage of diverse geographic origin. Ammonites characteristic of the Boreal Realm include Kepplerites, Cranocephalites, and Arctocephalites. Ammonites characteristic of the Pacific Realm from southern Alaska to Oregon include Xenocephalites, Cobbanites, Iniskinites, and Parareineckeia. Ammonites found to date only in southern Alaska include Tuxednites n. gen., Talkeetnites n. gen., and Chinitnites. Ammonites that occur nearly worldwide in the Bathonian, but are uncommon in the arctic region, include Phylloceras, Macrophylloceras, Calliphylloceras, and Lytoceras. Ammonites that occurred nearly worldwide except in the arctic region include Siemeradzkia?, $\mathrm{Ca}$ domites, and perhaps Oecotraustes.

\section{GEOGRAPHIC DISTRIBUTION}

The geographic occurrences of the ammonites described herein are shown in figures 8-11 and tables 2 and 3. Detailed descriptions of the occurrences are given in table 4.

\section{SYSTEMATIC DESCRIPTIONS}

\footnotetext{
Family PHYLLOCERATIDAE Zittel, 1884 Subfamily PHYLLOCERATINAE Zittel, 1884 Genus PHYLLOCERAS Suess, 1865

Phylloceras cf. P. bakeri ImIay

Plate 1, figures 6, 10
}

Two small specimens have ribbing identical with that on $P$. bakeri Imlay $(1953$, p. 72 , pl. 25 , figs. 10,14 ) at a comparable size and probably are immature forms of that species.

Figured specimen.-USNM 240705.

Occurrence.-Bowser Formation at USGS Mesozoic localities 21311 and 21312 on Gaikema Creek in the Chinitna Bay area. These occurrences are, respectively, 910-930 feet and 980 feet above the base of the formation, which at that place is 1,520 feet thick.

\footnotetext{
Subgenus MACROPHYLLOCERAS Spath, 1927

Phylloceras (Macrophylloceras) grossicostatum Imlay Plate 1, figures 12,13
}

Phylloceras (Macrophylloceras) grossicostatum Imlay, 1953, U.S. Geol. Survey Prof. Paper 249-B, p. 74, pl. 25, figs. 11-13, 15, 16.

This species is represented by 13 septate specimens of various sizes that match very well the type specimens from the Chinitna Formation.

Figured specimen.-USNM 240706.

Occurrence.-Bowser Formation at USGS Mesozoic localities 21311, 21312, and 22436 west of Cook Inlet. Equivalent unnamed beds in the Talkeetna Mountains at Mesozoic locality 30574.

\section{Subfamily CALLIPHYLLOCERATINAE Spath, 1927 Genus CALLIPHYLLOCERAS Spath, 1927 \\ Calliphylloceras freibrocki (Imlay) Plate 1, figures 7-9, 11}

Phylloceras (Calliphylloceras) freibrocki Imlay, 1953, U.S. Geol. Survey Prof. Paper 249-B, p. 73, pl. 26, figs. 7-11.

The species is represented by 12 specimens of various sizes; some show faint ribs or striae on the venter. These specimens are assigned to Calliphylloceras rather than Holcophylloceras because they lack distinct ribs on the venter and because their constrictions do not affect the test.

Types.-Holotype, USNM 108006; paratypes, USNM 108007, 108008; hypotypes, USNM 240707, 240708.

Occurrence.-Bowser Formation at USGS Mesozoic locality 21311, 21312, and 22712 west of Cook Inlet. Equivalent unnamed beds in the Talkeetna Mountains at Mesozoic localities 24117, 30275, and 30576-30578.

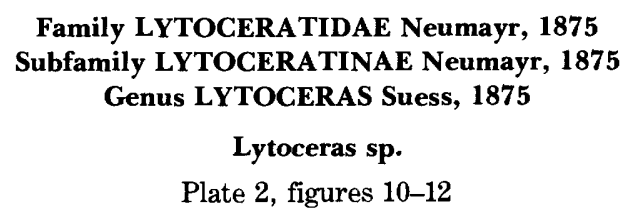

One septate internal mold shows evolute coiling, a nearly round whorl section, and crinkled riblets that incline gently forward on the flanks but cross the venter transversely. Constrictions are not present. The specimen closely resembles Lytoceras eudisianum (d'Orbigny) 


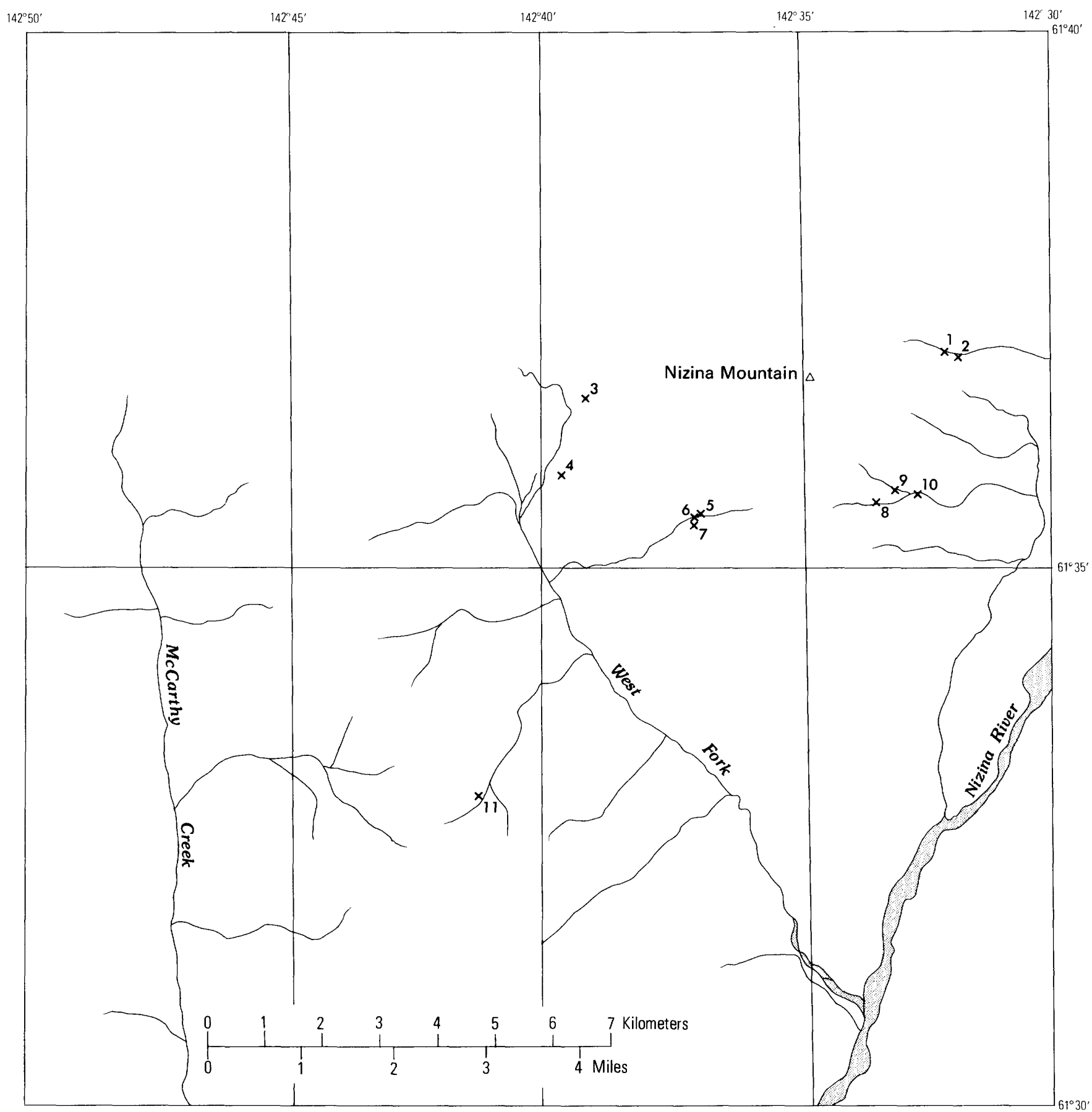

FIǴURE 8.-Index map of listed Bathonian fossil localities in the Nizina Mountain Formation in the Wrangell Mountains, Alaska. Numbers on map refer to those given in table 4.

as figured by J. Wendt (1963, p. 116, pl. 17, fig. 2) but lacks the flared ribs of the holotype as figured by d'Orbigny (1845, pl. 128).

Figured specimen.-USNM 240709.

Occurrence.-Unnamed beds in the Talkeetna Mountains at USGS Mesozoic locality 30579. One small fragment of Lytoceras occurs also in the Bowser Formation on the Iniskin Peninsula at Mesozoic locality 20739.
Family OPPELIIDAE Bonarelli, 1894 Subfamily OPPELIINAE Bonarelli, 1894 Genus OPPELIA Waagen, 1869 Subgenus OXYCERITES Rollier, 1909 Oppelia (Oxycerites) aff. O. (O.) chinitnana Imlay Plate 3, figures 1-5

One septate specimen differs from $O$. (O.) chinitnana Imlay (1953, p. 74, pl. 26, figs. 3-6) from the Chinitna 


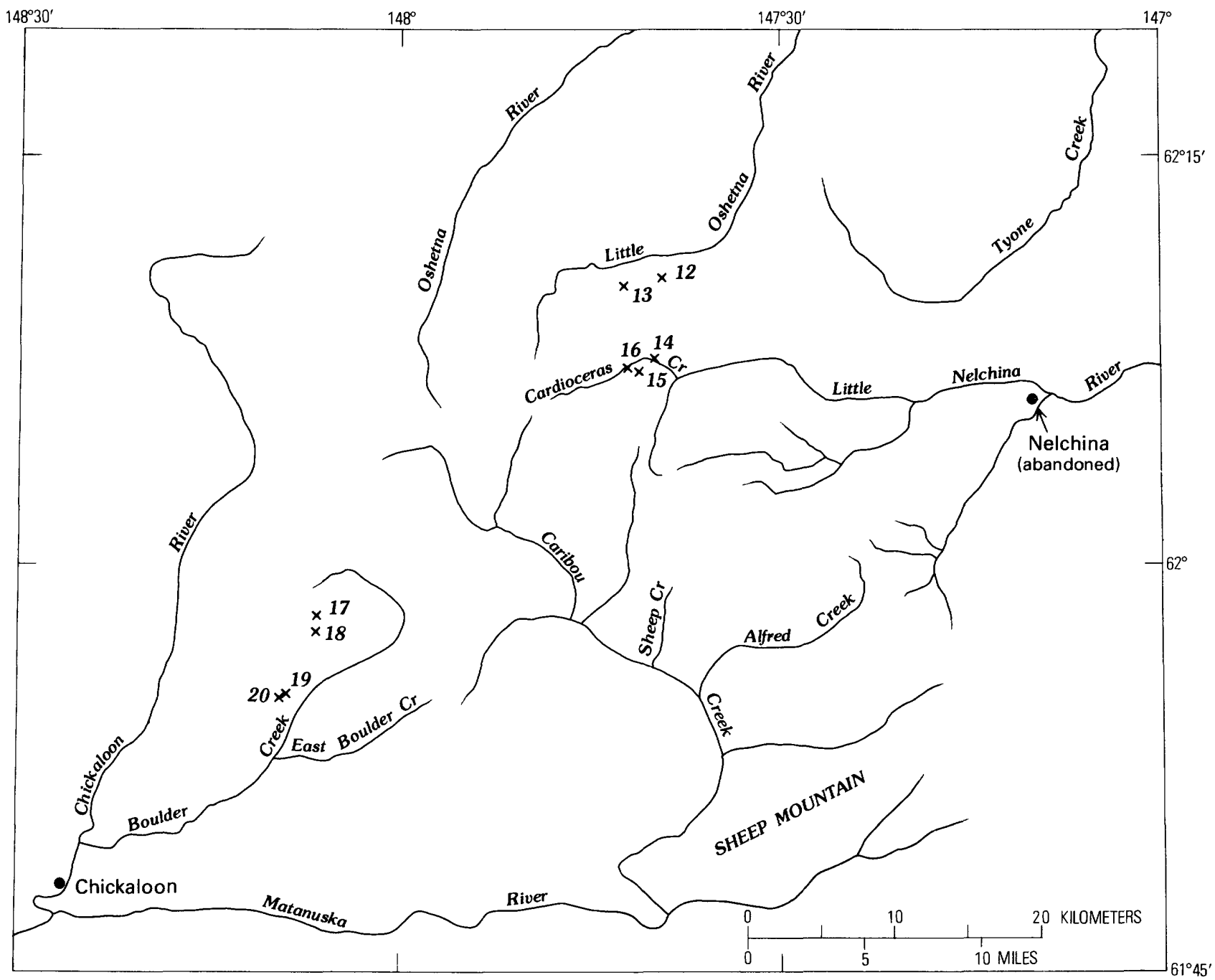

FIGURE 9.-Index map of listed Bathonian fossil localities in unnamed beds in the Talkeetna Mountains, Alaska. Numbers on map refer to those given in table 4 .

Formation in southern Alaska by having much weaker and more widely spaced sickle-shaped ribs on the upper parts of its flanks. Those ribs are stronger and appear earlier than in another specimen of $O$. (Oxycerites) from that formation (Imlay, 1953, p. 75. pl. 26, figs. 1, 2).

Figured specimen.-USNM 240710.

Occurrence.-Bowser Formation, 160-210 feet below top in the Tuxedni Bay area at USGS Mesozoic locality 22538.

\section{Subgenus LIROXYITES Imlay, 1962}

Oppelia (Liroxyites) cf. O. (L.) kellumi Imlay

Plate 3, figure 6

One fragmentary ammonite differs from the most coarsely ribbed specimens of $O$. (L.) kellumi Imlay (1962b, p. A-8, pl. 2, figs. 7,10$)$ at a comparable size by its ribs being almost falcate and somewhat broader and stronger on the upper part of the flank. One spiral band occurs near the middle of the flank where the ribs bend rather abruptly. The keel is pinched at its base. The umbilicus is not preserved but must have been very small.

Figured specimen.-USNM 240711.

Occurrence.-Bowser Formation, 300 feet below top, at USGS Mesozoic locality 30257 in the Tuxedni Bay area.

\section{Family SPHAEROCERATIDAE Buckman, 1920 Genus CADOMITES Munier-Chalmas, 1892}

Cadomites cf. C. deslongchampsi (d'Orbigny)

Plate 4, figures 1, 2, 4-12

cf. Ammonites deslongchampsi (d'Orbigny), 1846, Paleontologie Francaise, Terrains Jurassiques, v. 1, p. 405, pl. 138, figs. 1, 2. 


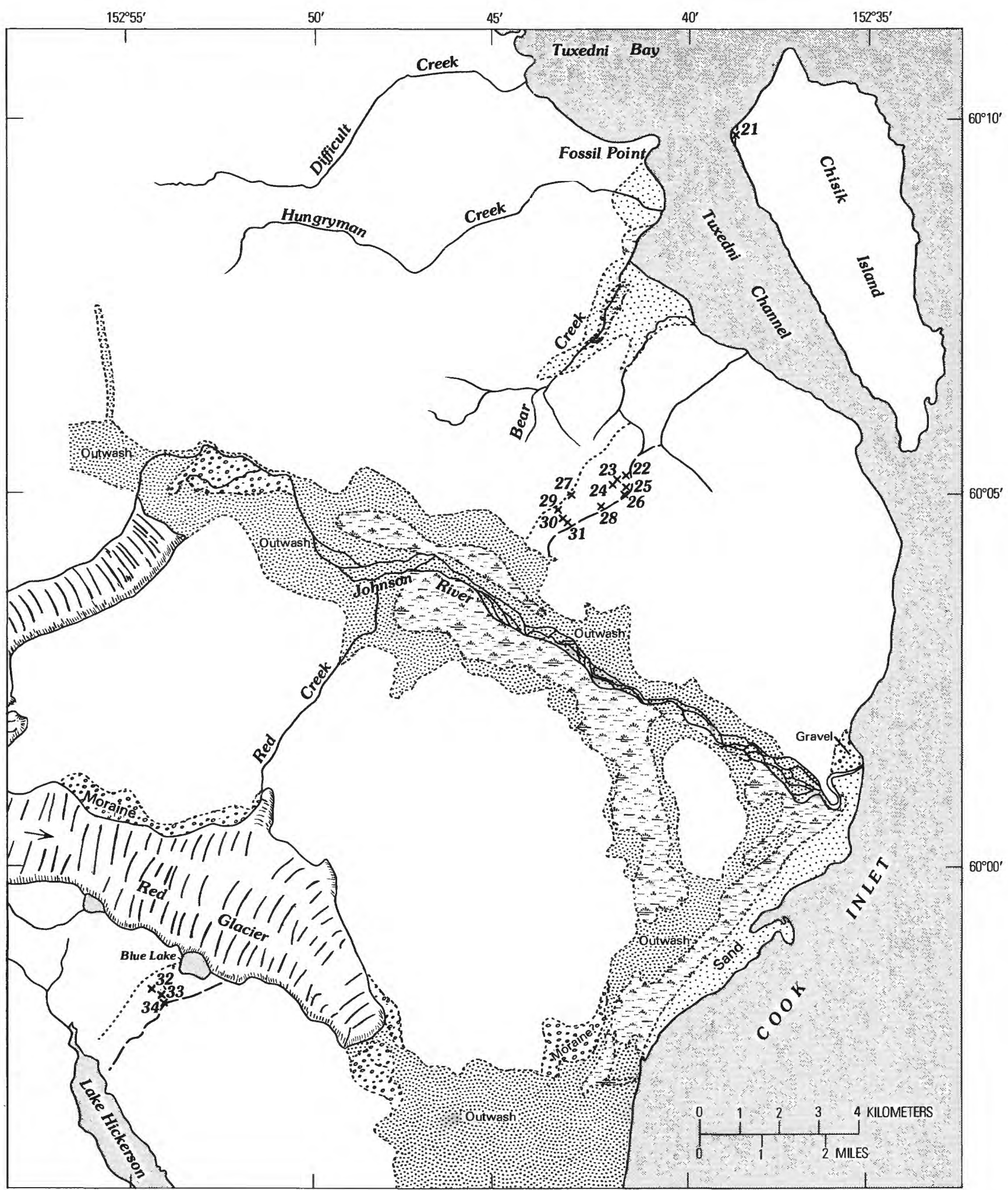

Figure 10.- Index map of listed Bathonian fossil localities in the Bowser Formation on Chisik Island and on the peninsula between Tuxedni Bay and Cook Inlet, Alaska. Numbers on map refer to those given in table 4. Base of Chinitna Formation is indicated by dashed lines. Base of Bowser Formation is indicated by dotted lines. 


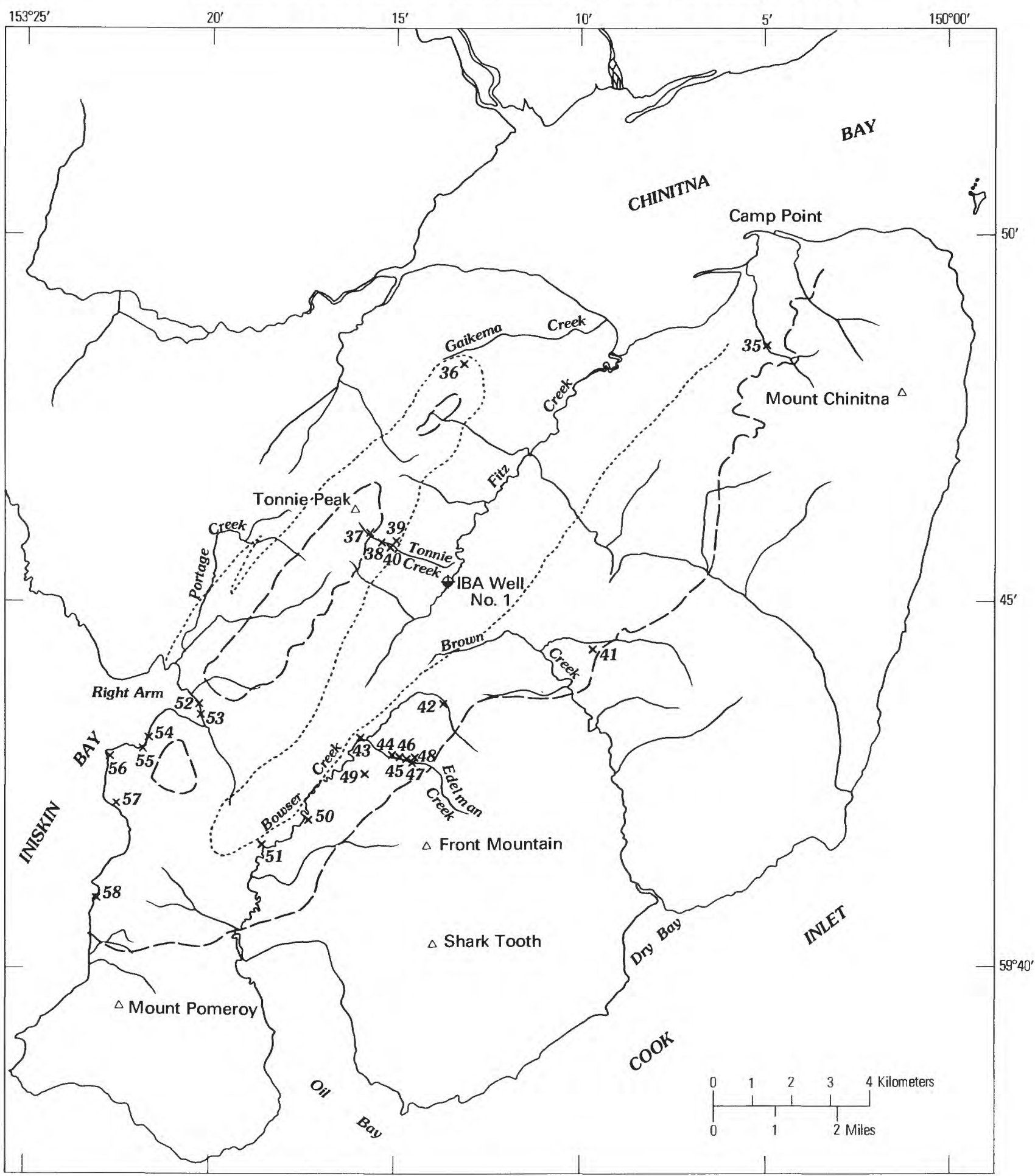

Figure 11.-Index map of listed Bathonian fossil localities in the Bowser Formation on Iniskin Peninsula west of Cook Inlet, Alaska. Numbers on map refer to those given in table 4. Base on Chinitna Formation is indicated by dashed lines. Base of Bowser Formation is indicated by dotted lines.

cf. Cadomites ef. C. deslongchampsi (d'Orbigny). Arkell, 1952, English Bathonian Ammonites, pt. 3, p. 79-81, text fig. 21, pl. 9 fig. $3 a$, b. cf. Cadomites deslongchampsi Defrance in Roman and Petourand, 1927, Travaux, Lyon Univ. Lab. Geol., pt. 11, mem. 9, p. 44, pl. 7, figs. 5a, b. 
TABLE 4.-Description of Bathonian fossil localities in southern Alaska

\begin{tabular}{|c|c|c|c|}
\hline 1 & 28524 & F28 & $\begin{array}{l}\text { E.M. Mackevett, D.L. Jones, and M. C. Blake, } 1961 . \\
\text { Wrangell Mountains. McCarthy (C-5) quad. SE. cor. } \\
\text { sec. 8, T. } 3 \text { S., R. } 16 \text { E., Nizina Mountain } \\
\text { Formation. }\end{array}$ \\
\hline 2 & 28525 & $61-60$ & $\begin{array}{l}\text { D. L. Jones, 1961. Wrangel1 Mountains. McCarthy } \\
(\mathrm{C}-5) \text { quad. SW. cor. Sec. 9, T. } 3 \text { S., R. } 16 \text { E., } \\
\text { Nizina Mountain Formation. }\end{array}$ \\
\hline 3 & 28527 & $61 \mathrm{ABC} 19$ & $\begin{array}{l}\text { M. C. Blake, Jr., 1961. Wrange } 11 \text { Mountains. } \\
\text { McCarthy }(C-5) \text { quad. SW. cor. NW } 3 \frac{1}{4} \text { sec. 14, T. } 3 \\
\text { S., R. } 15 \text { E., Nizina Mountain Formation, lower } \\
\text { part, a few hundred feet above the Lubbe Creek } \\
\text { Formation. }\end{array}$ \\
\hline 3 & 28699 & 62 AMK 48 & $\begin{array}{l}\text { R. W. Imlay and E. M. Mackevett, 1962, Wrange } 11 \\
\text { Mountains. Float from Nizina Mountain Formation } \\
\text { at same place as locality } 28527 \text {. }\end{array}$ \\
\hline 4 & 28526 & $62 \mathrm{ABC} 33$ & 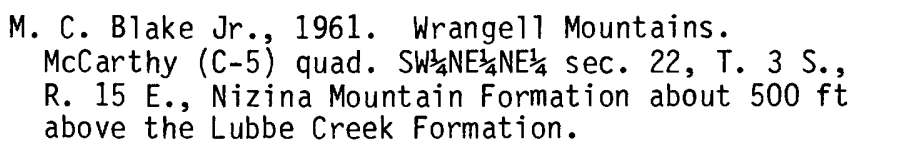 \\
\hline 5 & 28692 & 62 AMK 32 & 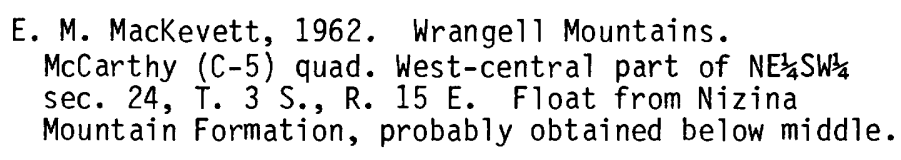 \\
\hline 8 & 28681 & 62 AMK 52 & 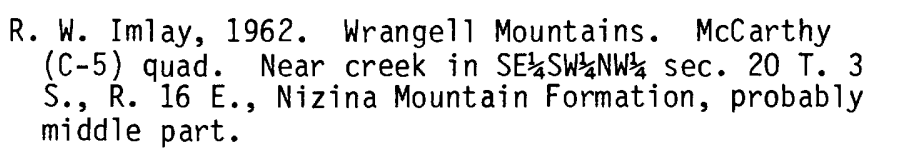 \\
\hline 9 & 28682 & 62 AMK 53 & 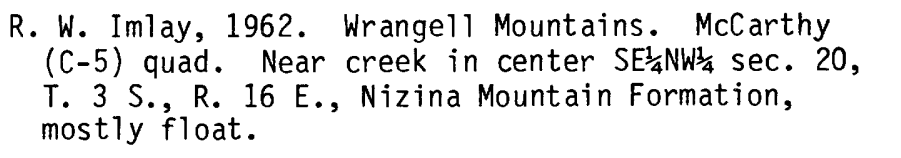 \\
\hline 9 & 28701 & 62 AMK $53 A$ & $\begin{array}{l}\text { E. M. Mackevett, 1962. Wrangell Mountains. About } \\
500 \mathrm{ft} \text { west of Mesozoic loc. } 28682 \text {. }\end{array}$ \\
\hline 10 & 28683 & 62 AMK 54A & $\begin{array}{l}\text { E. M. Mackevett, 1962. Wrangell Mountains. } \\
\text { McCarthy C-5 quad. Near creek in center SW } \frac{1}{4} N E^{\frac{1}{4}} \\
\text { sec. } 20 \text {, T. } 3 \text { S., R. } 16 \mathrm{E} \text {., Nizina Mount ain } \\
\text { Formation, near base. }\end{array}$ \\
\hline
\end{tabular}


TABLE 4.-Description of Bathonian fossil localities in southern Alaska-Continued

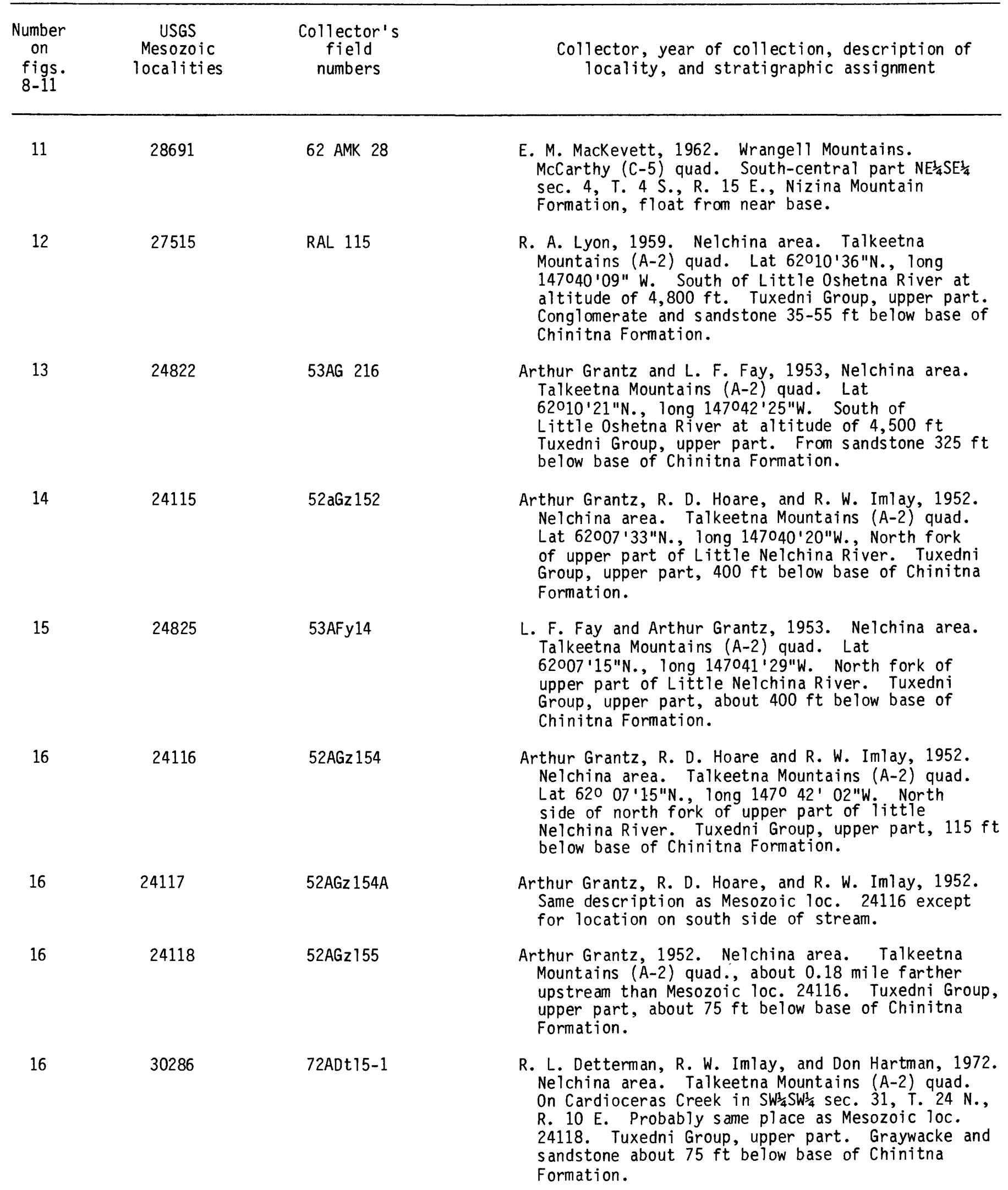


TABLE 4.-Description of Bathonian fossil localities in southern Alaska-Continued

\begin{tabular}{|c|c|c|c|}
\hline $\begin{array}{l}\text { Number } \\
\text { on } \\
\text { figs. } \\
\text { 8-11 }\end{array}$ & $\begin{array}{c}\text { USGS } \\
\text { Mesozoic } \\
\text { localities }\end{array}$ & $\begin{array}{c}\text { Collector's } \\
\text { field } \\
\text { numbers }\end{array}$ & $\begin{array}{l}\text { Collector, year of collection, description of } \\
\text { locality, and stratigraphic assignment }\end{array}$ \\
\hline
\end{tabular}

16

16

16

16

17

17

17

17

17
30287

30288

30289

30290

30274

30275

30276

30276

30277
72ADt 11-2

72ADt 15-2

72ADt $15-3$

72ADt $16-1$

72ADt 16-2

72ADt 11-1

$2 A D+11-3$

72ADt $11-3$

72ADt 11-4
R. L. Detterman, R. W. Imlay, and Don Hartman, 1972. Same location as Mesozo ic loc. 30286. Tuxedni Group, upper part. Graywacke and brown siltstone containing limy concretions about $100 \mathrm{ft}$ below base of Chinitna Formation.

R. L. Detterman, R. W. Imlay, and Don Hartman, 1972. Tuxedni Group, upper part. Same location as Mesozoic loc. 30286. In siltstone containing limy concretions about $115 \mathrm{ft}$ below base of Chinitna Formation.

R. L. Detterman, R. W. Imlay, and Don Hartman, 1972. Nelchina area. Talkeetna Mountains (A-2) quad. On south side of Cardioceras Creek directly across river from Mesozoic 10c. 30288. Near southern boundary of south-central part of $\mathrm{SW}_{\frac{1}{4}} \mathrm{SW}_{\frac{1}{4}}$ sec. 31, T. 24 N, R. 10 E. Tuxedni Group, upper part. Massive graywacke about $165 \mathrm{ft}$ below base of Chinitna Formation.

R. L. Detterman, R. W. Imlay, and Don Hartman, 1972. Nelchina area. Talkeetna Mountains (A-2) quad. Near Mesozoic loc. 30289 but about $50 \mathrm{ft}$ higher stratigraphically. Tuxedni Group, upper part. Siltstone $165 \mathrm{ft}$ below base of Chinitna Formation.

R. L. Detterman, R. W. Imlay, and Don Hartman, 1972. Boulder Creek area. Talkeetna Mountains. Anchorage (D-3) quad. On ridge trending northwest from peak that is 1.2 miles S. $350 \mathrm{~W}$. of VABM

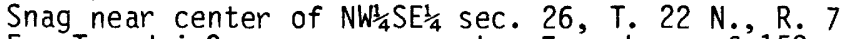
E., Tuxedni Group, upper part. From base of' 150 $\mathrm{ft}$ of volcanic graywacke underlying basal conglomerate of Chinitna Formation.

R. L. Detterman, R. W. Imlay, and Don Hartman, 1972. Boulder Creek area in Talkeetna Mountains. Same location as Mesozoic loc. 30274 but from 170-215 $\mathrm{ft}$ below base of Chinitna Formation in gray siltstone bearing limy concretions.

R. L. Detterman, R. W. Imlay, and Don Hartman, 1972. Same description as Mesozoic loc. 30275 but from 255 to $295 \mathrm{ft}$ below base of Chinitna Formation.

R. L. Detterman, R. W. Imlay, and Don Hartman, 1972. Same description as Mesozoic 10c. 30275 but from 255 to $295 \mathrm{ft}$ below base of Chinitna Formation.

R. L. Detterman, R. W. Imlay, and Don Hartman, 1972. Same description as Mesozoic 10c. 30275 but from 293-375 ft below base of Chinitna Formation. 
TABLE 4.-Description of Bathonian fossil localities in southern Alaska-Continued

\begin{tabular}{|c|c|c|c|}
\hline $\begin{array}{l}\text { Number } \\
\text { on } \\
\text { figs. } \\
8-11\end{array}$ & $\begin{array}{l}\text { USGS } \\
\text { Mesozoic } \\
\text { localities }\end{array}$ & $\begin{array}{l}\text { Collector's } \\
\text { field } \\
\text { numbers }\end{array}$ & $\begin{array}{l}\text { Collector, year of collection, description of } \\
\text { locality, and stratigraphic assignment }\end{array}$ \\
\hline 17 & 30278 & $72 A D t 11-5$ & $\begin{array}{l}\text { R. L. Detterman, R. W. Imlay, and Don Hartman, } \\
1972 \text {. Same description as Mesozoic loc. } 30275 \text { but } \\
\text { from } 375 \text { to } 405 \mathrm{ft} \text { below base of Chinitna } \\
\text { Formation in brown siltstone. }\end{array}$ \\
\hline 17 & 30279 & 72ADt11-6 & $\begin{array}{l}\text { R. L. Detterman, R. W. Imlay, and Don Hartman, } 1972 \text {. } \\
\text { Same description as Mesozoic loc. } 30275 \text { but from } \\
405 \text { to } 475 \mathrm{ft} \text { below base of Chinitna Formation in } \\
\text { graywacke. }\end{array}$ \\
\hline 17 & 30574 & $74 \mathrm{AI2}$ & $\begin{array}{l}\text { R. W. Imlay and Jordan Pflaker, 1974. Same } \\
\text { description as Mesozoic loc. 30275. }\end{array}$ \\
\hline 17 & 30575 & $74 \mathrm{AI3}$ & $\begin{array}{l}\text { R. W. Imlay and Jordan Pflaker, 1974. Same } \\
\text { description as Mesozoic loc. } 30275 \text { but from } 215 \text { to } \\
260 \mathrm{ft} \text { below base of Chinitna Formation. }\end{array}$ \\
\hline 17 & 30576 & 74AI4 & $\begin{array}{l}\text { R. W. Imlay and Jordan Pflaker, 1974. Same } \\
\text { description as Mesozoic loc. 30276, but most } \\
\text { fossils are from upper } 40 \mathrm{ft} \text {. }\end{array}$ \\
\hline 17 & 30577 & $74 A I 5$ & $\begin{array}{l}\text { R. W. Imlay and Jordan Pflaker, 1974. Same } \\
\text { description as Mesozoic loc. } 30277 \text {, but most } \\
\text { fossils are from upper } 40 \mathrm{ft} \text {. }\end{array}$ \\
\hline 17 & 30578 & $74 \mathrm{AI} 6$ & $\begin{array}{l}\text { R. W. Imlay and Jordan Pflaker, 1974. Same } \\
\text { description as Mesozoic 1oc. 30278. }\end{array}$ \\
\hline 17 & 30579 & $74 \mathrm{AI7}$ & $\begin{array}{l}\text { R. W. Imlay and Jordan Pflaker, 1974. Same } \\
\text { description as Mesozoic loc. 30279. }\end{array}$ \\
\hline 17 & & RAL65 & $\begin{array}{l}\text { R. A. Lyons, 1960?. On same ridge and same sequence } \\
\text { as USGS Mesozoic locs. 30275-30279. }\end{array}$ \\
\hline 18 & 30292 & $72 A D t 18$ & $\begin{array}{l}\text { R. W. Imlay and Don Hartman, } 1972 \text {. Boulder Creek } \\
\text { area in Talkeetna Mount ains. Anchorage (D-4) } \\
\text { quad. On east side of tributary of Boulder Creek, } \\
5.2 \text { miles } \mathrm{N} \text {. } 170 \mathrm{E} \text {. of junction of main creek } \\
\text { with East Boulder Creek in south-central part of } \\
\text { NW! sec. } 35 \mathrm{~T} 22 \mathrm{~N} \text {., R. } 7 \mathrm{E} \text {. Tuxedni Group, } \\
\text { upper part. In siltstone and some interbedded } \\
\text { graywacke iying at least } 150 \mathrm{ft} \text { below base of } \\
\text { Chinitna Formation. }\end{array}$ \\
\hline 19 & 8573 & $13 \mathrm{AMa} 22$ & $\begin{array}{l}\text { Martin, G. C., 1913. Boulder Creek area in } \\
\text { Talkeetna Mountains. Anchorage }(D-4) \text { quad. } \\
\text { South-central part of NW/4 sec. } 10, T .21 \mathrm{~N} \text {. } \mathrm{R} .7 \\
\mathrm{E} ., \text { at altitude of } 3,400 \mathrm{ft} \text { on north side of knob, } \\
1 \text { mile northwest of Boulder Creek and } 3 \text { miles } \mathrm{N} \text {. } \\
110 \mathrm{E} \text {. of mouth of East Boulder Creek. Tuxedni } \\
\text { Group, upper part, underlying Chinitna Formation. }\end{array}$ \\
\hline 20 & 30271 & 72ADt $10-1$ & $\begin{array}{l}\text { R. L. Detterman, R. W. Imlay, and Don Hartman, } \\
1972 \text {. Boulder Creek area in Talkeetna Mountains. } \\
\text { Anchorage (D-4) quad. In gully } 2.6 \text { miles } \mathrm{N} \text {. } 70 \\
\text { E. of junction of Boulder and East Boulder Creeks } \\
\text { in west-central part of SW }{ }^{\frac{1}{4}} \text { sec. } 10, T \text {. } 21 \mathrm{~N} . \text {, R. } \\
6 \text { E. Tuxedni Group, upper part. Siltstone- } \\
\text { bearing cannonball concretions beneath Tertiary } \\
\text { lava flows. }\end{array}$ \\
\hline
\end{tabular}


TABLE 4.-Description of Bathonian fossil localities in southern Alaska-Continued

\begin{tabular}{|c|c|c|c|}
\hline $\begin{array}{c}\text { Number } \\
\text { on } \\
\text { figs. } \\
8-11\end{array}$ & $\begin{array}{c}\text { USGS } \\
\text { Mesozoic } \\
\text { localities }\end{array}$ & $\begin{array}{c}\text { Collector's } \\
\text { field } \\
\text { numbers }\end{array}$ & $\begin{array}{l}\text { Collector, year of collection, description of } \\
\text { locality, and stratigraphic assignment }\end{array}$ \\
\hline
\end{tabular}

20

20

30273

3014

21

30261

48AI84
918

72ADt6A

72ADt $10-2$

$72 A D t 10-3$

$48 \mathrm{AI} 68$

72ADt 8

72ADt 7

72ADt3
Detterman, R. W. Imlay, and Don Hartman, 972. Same place as Mesozoic loc. 30271, but about $30 \mathrm{ft}$ lower stratigraphically.

L. Detterman, R. W. Imlay, and Don Hartman, Tuxedni Group, upper part. Float in gulley

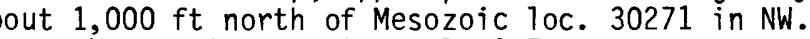
cor. SW $\frac{1}{4}$ sec. 10, T. 21 N., R. 6 E.

- W. Stanton, 1904. North side of Cook Inlet in Tuxedni Bay area at north end of Chisik Island; Kenai (A-8) quad. 1.25 miles S. $810 \mathrm{E}$. of Fossil Point in sec. 19, T. 1 N., R. 19 W. Bowser ormation $1 \mathrm{ft}$ below top, just below conglomerate at base of Chinitna Formation.

Miller and R. W. Imlay, 1948. Tuxedni Bay Kenai $(A-8)$ quad. Same place as Mesozoic

W. Iml ay and R. L. Detterman, 1972. Tuxedni Bay area. Kenai (A-8) quad. 1.4 miles S. $400 \mathrm{~W}$. of small stream entering Tuxedni Channel rom southwest opposite Chisik Island.

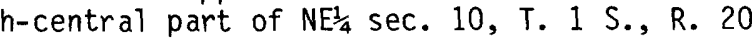
. Bowser Formation $100 \mathrm{ft}$ below top in siltstone containing sandstone interbeds.

L. Detterman, and R. W. Imlay, 1972. Tuxedni Bay area. Kenai $(A-8)$ quad. Near center SW $W_{4}^{\frac{1}{4}} \mathrm{NE}^{\frac{1}{4}} \mathrm{sec}$. 10, T. I S., R. 20 W. Bowser Formation about 300 t below top.

L. Detterman and R. W. Imlay, 1972. Tuxedni Bay area. Kenai $(A-8)$ quad. SW. cor. NE $\frac{1}{4}$ sec. 10, T. S., R. 20 W., about 1.6 miles S. 430 W. of mouth of stream. Bowser Formation about $300 \mathrm{ft}$

R. L. Detterman and R. W. Imlay, 1972. Tuxedni Bay

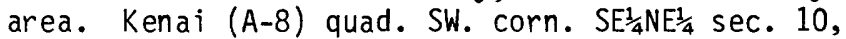
T. I S., R. 20 W., 1.6 miles S. $380 \mathrm{~W}$. of mouth of stream. Bowser Formation about $150 \mathrm{ft}$ below top in brownish siltstone.

R. W. Imlay and D. J. Miller, 1948. Tuxedni Bay area. Kenai (A-8) quad., 4.1 miles S. $120 \mathrm{~W}$. of

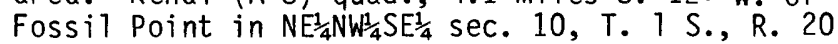
$W$. Bowser Formation 900-950 ft above base and 300-350 ft below top in brownish siltstone.

R. W. Imlay and D. J. Miller, 1948. Tuxedni Bay area. Kenai $(A-8)$ quad. First outcrop above mouth of stream entering Bear Creek from southeast 4.2 miles S. $200 \mathrm{~W}$. of Fossil Point, slightly south of center of $\mathrm{NE}^{\frac{1}{4}} \mathrm{SE}^{\frac{1}{4}} \mathrm{sec} .9$, T. 1 S., R. 20 W. Bowser Formation about $500 \mathrm{ft}$ above base and $750 \mathrm{ft}$ below top in gray siltstone. 
TABLE 4.-Description of Bathonian fossil localities in southern Alaska-Continued

$\begin{array}{ccc}\begin{array}{c}\text { Number } \\ \text { on } \\ \text { figs. }\end{array} & \text { USGS } & \text { Collector's } \\ \text { 8-11 } & \text { localities } & \text { field } \\ \text { numbers } & \text { Collector, year of collection, description of } \\ \text { locality, and stratigraphic assignment }\end{array}$

28

$$
30258
$$

$72 \mathrm{ADt} 4$

29

51 AGz 143
R. W. Imlay and D. J. Miller, 1948. Tuxedni Bay area. Kenai (A-8) quad., 2.1 miles S. $400 \mathrm{~W}$. of mouth of small stream entering Tuxedni Channel from southwest. North-central part of $\mathrm{NW}^{2} \frac{1}{4} \mathrm{SE}_{\frac{1}{4}} \mathrm{SW}^{\frac{1}{4}}$ sec. 10, T. I S., R. 20 W. Bowser Formation 50-75 $\mathrm{ft}$ below top in brownish siltstone.

Arthur Grantz, 1951. Tuxedni Bay area. Kenai (A-8) quad., $0.38 \mathrm{mile}$ above mouth of tributary entering Bear Creek from southeast. Near center $\mathrm{SW}_{\frac{1}{4}} \mathrm{SE}^{\frac{1}{4}} \mathrm{sec}$. 9., T. I S., R. $20 \mathrm{~W}$. Bowser Formation about $100 \mathrm{ft}$ above base.

Arthur Grantz, 1951. Tuxedni Bay area. Kenai (A-8) quad., 0.45 mile above mouth of tributary entering Bear Creek from southeast. East-central part SW $\frac{1}{4} \mathrm{SE}^{\frac{1}{4}} \mathrm{Sec}$. 9, T. 1 S., R. $20 \mathrm{~W}$., Bowser Formation about $150 \mathrm{ft}$ above base.

Arthur Grantz, 1951. Tuxedni Bay area. Kenai (A-8) quad., 0.62 mile above mouth of tributary entering Bear Creek from southeast. East central part SE $\frac{1}{4} S_{\frac{1}{4}}$ sec. 9, T. I S., R. $20 \mathrm{~W}$. Bowser Formation about $750 \mathrm{ft}$ above base and $500 \mathrm{ft}$ below top.

Arthur Grantz, 1951. Tuxedni Bay area. Kenai (A-8) quad., $0.67 \mathrm{mile}$ above mouth of same tributary described under Mesozoic loc. 22711. SW. cor. SE $\frac{1}{4} S^{\frac{1}{4}}$ sec. 9, T. I S., R. 20 W. Bowser Formation about $900 \mathrm{ft}$ above base and $350 \mathrm{ft}$ below top.

Arthur Grantz, 1951. Lake Hickerson area. Seldovia (D-8) quad., on ridge 1.5 miles N. 39050 ' . $_{\text {. of }}$ head of Lake Hickerson. NW. cor. SW $\frac{1}{4}$ sec. $28, T$. 2 S., R. 21 W., Bowser Formation $690 \mathrm{ft}$ above base and $1,010 \mathrm{ft}$ below top.

Arthur Grantz, 1951. Lake Hickerson area. Seldovia (D-8) quad., on ridge 1.62 miles N. $510 \mathrm{E}$. of

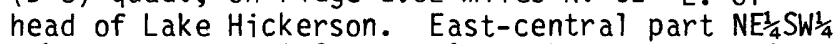
$\mathrm{SW}^{\frac{1}{4}}$ sec. 28, T. 2 S., R. 21 W., Bowser Formation 360-399 $\mathrm{ft}$ below top.

Arthur Grantz, 1951. Lake Hickerson area. Seldovia (D-8) quad., on ridge 1.7 miles N. $510 \mathrm{E}$. of

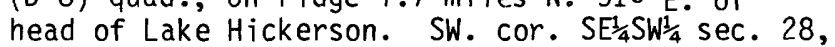
T. 2 S., R. 21 W., Bowser Formation about $240 \mathrm{ft}$ below top.

R. W. Imlay and D. J. Miller, 1948. Iniskin Peninsula. Iliamna (D-1) quad., 1.92 miles $N$. $890 \mathrm{E}$. of dock at mouth of Fitz Creek. West central part NW/ NW/ $\frac{1}{4}$ sec. 28, T. 4 S., R. 22 W. Bowser Formation 550-600 ft below top and 920-970 $\mathrm{ft}$ above base. 
TABLE 4.-Description of Bathonian fossil localities in southern Alaska-Continued

\begin{tabular}{|c|c|c|c|}
\hline $\begin{array}{c}\text { Number } \\
\text { on } \\
\text { figs. } \\
8-11\end{array}$ & $\begin{array}{c}\text { USGS } \\
\text { Mesozoic } \\
\text { localities }\end{array}$ & $\begin{array}{c}\text { Collector's } \\
\text { field } \\
\text { numbers }\end{array}$ & $\begin{array}{l}\text { Collector, year of collection, description of } \\
\text { locality, and stratigraphic assignment }\end{array}$ \\
\hline
\end{tabular}

35

21312

$48 \mathrm{AI} 17$

35

22436

21308

$48 \mathrm{AI}]$

36

36

21309

48AI2

20011

44AWW

27100

58ADt3

40

20005

40
R. W. Imlay and D. J. Miller, 1948. Iniskin Peninsula. Iliamna (D-1) quad., 1.9 miles $N$. $860 \mathrm{E}$. of dock at mouth of Fitz Creek near center NW $\frac{1}{4} N^{\frac{1}{4}}$ sec. $28, T .4$ S., R. 22 W. Bowser Formation about $70 \mathrm{ft}$ higher than Mesozoic loc. 21311.

J. K. Hartsock, 1950. Iniskin Peninsula. Same description as Mesozoic 10c. 21312. Bowser Formation about $380 \mathrm{ft}$ above base.

R. W. Imlay and D. J. Miller, 1948. Iniskin Peninsula. Iliamna (D-1) quad., 2.4 miles $S$. $840 \mathrm{~W}$. of dock at mouth of Fitz Creek. SW. cor. SE $\frac{1}{4} N W \frac{1}{4}$ of sec. 27 , T. 4 S., R. 23 W. Bowser Formation about $380 \mathrm{ft}$ above base and $1,140 \mathrm{ft}$ below top.

R. W. Imlay and D. J. Miller, 1948. Iniskin Peninsula. Iliamna (D-1) quad., 2.3 miles $S$. $860 \mathrm{~W}$. of dock at mouth of Fitz Creek.

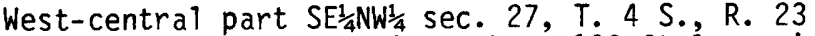
W. Bowser Formation. Float about $100 \mathrm{ft}$ lower in gulch than at Mesozoic 1oc. 21308.

R. W. Imlay and D. J. Miller, 1948. Iniskin Peninsula. Iliamna (D-1) quad., 0.65 mile $S$.

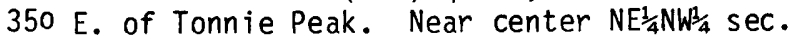
7, T. 5 S., R. 23 W. Bowser Formation about $410 \mathrm{ft}$ bel ow top.

Helmuth Wedow and L. B. Kellum, 1944. Iniskin Peninsula. Iliamna (D-1) quad., 1 mile up Tonnie Creek from trail just above crest of third falls.

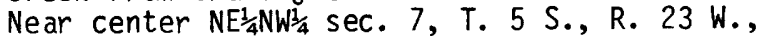
Bowser Formation about $840 \mathrm{ft}$ above base and 990 ft below top.

R. L. Detterman, 1958. Iniskin Peninsula. Iliamna (D-1) quad. On Tonnie Creek, 0.94 mile N. 610 W. of I. B. A. No. I well. Near center of NE⿺ sec. 7, T. 5 S., R. 23 W. Bowser Formation about $90 \mathrm{ft}$ above base.

L. B. Kellum, 1944. Iniskin Peninsula. Iliamna (D-1) quad. Southwest side of Tonnie Creek about $700 \mathrm{ft}$ upstream from lower cascade and $0.85 \mathrm{mile}$ S. $560 \mathrm{E}$. of Tonnie Peak. North central part $\mathrm{NE}^{\frac{1}{4}} \mathrm{sec}$. 7. T. 5 S., R. 23 W. Bowser Formation 125 to $150 \mathrm{ft}$ above base.

R. W. Imlay and R. L. Detterman, 1972. Iniskin Peninsula. Iliamna (D-1) quad. On Tonnie Creek $0.6 \mathrm{mile}$ S. $400 \mathrm{E}$. of Tonnie Peak. West-central part of NW $\frac{1}{4} N^{\frac{1}{4}}$ sec. 7, T. 5 S., R. 23 W. Bowser Formation about $300 \mathrm{ft}$ above base in brownish siltstone. 
TABLE 4.-Description of Bathonian fossil localities in southern Alaska-Continued

\begin{tabular}{|c|c|c|c|}
\hline $\begin{array}{c}\text { Number } \\
\text { on } \\
\text { figs. } \\
8-11\end{array}$ & $\begin{array}{c}\text { USGS } \\
\text { Mesozoic } \\
\text { localities }\end{array}$ & $\begin{array}{c}\text { Collector's } \\
\text { field } \\
\text { numbers }\end{array}$ & $\begin{array}{l}\text { Collector, year of collection, description of } \\
\text { locality, and stratigraphic assignment }\end{array}$ \\
\hline
\end{tabular}

41

22549

42

11038

$21 \mathrm{AB} 46$

43

44

20745

$46 \mathrm{AKr} 155$

45

20746

$46 \operatorname{AKr} 156$

46

11042

47

48

48AI49

49

46AK 164

49

46 AKr 177

$46 \mathrm{AKr} 158$

50
21320

20751

20752

20743

20748

2073
$50 \mathrm{AHa} 63$

(S)

J. K. Hartsock, 1950. Iniskin Peninsula. Iliamna (C-1) quad., 4.08 miles N. 410 E. of Front Mountain on tributary to Brown Creek. NE. cor. SW $\frac{1}{4}$ sec. 14, T. 5 S., R. 23 W. Bowser Formation 280-380 ft below top.

A. A. Baker, 1921. Iniskin Peninsula. Iliamna (C-1) quad., about 2.2 miles N. $80 \mathrm{E}$. of Front

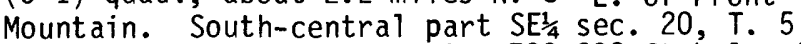
S., R. 23 W. Bowser Formation $700-800 \mathrm{ft}$ below top.

C. E. Kirschner, 1946. Iniskin Peninsula. Iliamna (C-1) quad., 2.0 miles N. 320W. of Front Mountain. North-central part of NW $\frac{1}{4} \mathrm{sec} .30$, T. 5 S., R. 23 W. Bowser Formation $300 \mathrm{ft}$ above base.

C. E. Kirschner, 1946. Iniskin Peninsula. Iliamna (C-1) quad. On Ede Iman Creek, 1.5 miles N 220 W. of Front Mountain. North-central part of $\mathrm{NE}^{\frac{1}{4}}$ $\mathrm{SE}_{\frac{1}{4}} \mathrm{sec} .30$, T. $5 \mathrm{~S}$., R. 23 W., Bowser Formation about $1,050 \mathrm{ft}$ above base and $780 \mathrm{ft}$ below top.

C. E. Kirschner, 1946. Iniskin Peninsula. Iliamna (C-1) quad. On Edelman Creek, 1.4 miles N. 220

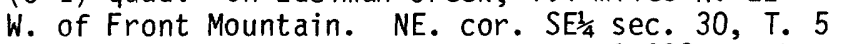
S., R. $23 \mathrm{~W}$. Bowser Formation about $1,200 \mathrm{ft}$ above base and $630 \mathrm{ft}$ below top.

A. A. Baker, 1921. Iniskin Peninsula. Iliamna (C-1) quad., 1.4 miles N. $150 \mathrm{~W}$. of Front Mountain. NW $\frac{1}{4} W_{\frac{1}{4}} S_{W}^{\frac{1}{4}}$ sec. 29, T. 5 S., R. 23 W. Bowser Formation about $610 \mathrm{ft}$ below top.

C. E. Kirschner, 1946. Iniskin Peninsula. Iliamna

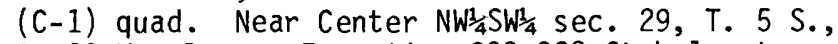
R. 23 W. Bowser Formation $230-280 \mathrm{ft}$ below top.

R. W. Imlay and D. J. Miller, 1948. Iniskin Peninsula. Illiamna $(C-1)$ quad., 4.7 miles $(7.5$

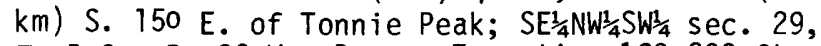
T. 5 S., R. 23 W. Bowser Formation $180-230 \mathrm{ft}$ below top.

C. E. Kirschner, 1946. Iniskin Peninsula. Iliamna (C-1) quad., 1.4 miles N. $400 \mathrm{~W}$. of Front

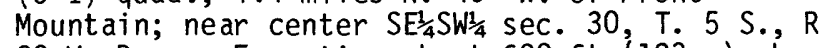
$23 \mathrm{~W}$. Bowser Formation about $600 \mathrm{ft}(183 \mathrm{~m})$ above base and $1,230 \mathrm{ft}$ below top.

C. E. Kirschner, 1946. Iniskin Peninsula. Iliamna (C-1) quad. Nearly same location as Mesozoic loc. 20751. Bowser Formation 650-680 ft above base.

C. E. Kirschner, 1946. Iniskin Peninsula. Iliamna (C-1) quad., 1.8 miles N. $850 \mathrm{~W}$. of Front

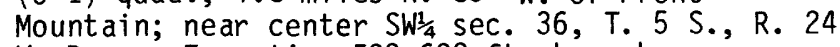
W. Bowser Formation 500-600 ft above base. 
TABLE 4.-Description of Bathonian fossil localities in southern Alaska-Continued

\begin{tabular}{|c|c|c|c|}
\hline $\begin{array}{l}\text { Number } \\
\text { on } \\
\text { figs. } \\
8-11\end{array}$ & $\begin{array}{l}\text { USGS } \\
\text { Mesozoic } \\
\text { localities }\end{array}$ & $\begin{array}{l}\text { Collector's } \\
\text { field } \\
\text { numbers }\end{array}$ & $\begin{array}{l}\text { Collector, year of collection, description of } \\
\text { locality, and stratigraphic assignment }\end{array}$ \\
\hline 51 & 20744 & 46 AKr 154 & 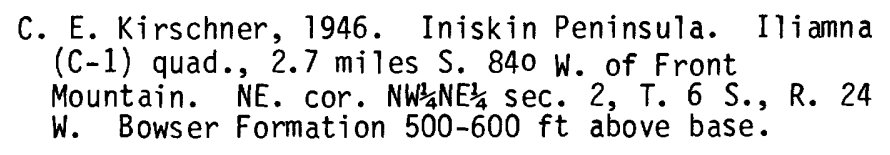 \\
\hline $52^{\circ}$ & 22536 & $50 A H i 5 b$ & $\begin{array}{l}\text { D. M. Hill and R. W. Juhle, } 1950 \text {. Iniskin } \\
\text { Peninsula. Iliamna (C-1) quad. On Right Arm } \\
\text { Iniskin Bay. About } 4.25 \text { miles } N \text {. } 580 \mathrm{~W} \text {. of } \\
\text { Front Mountain. South-central part of SE⿺ } \mathrm{sec} \text {. } \\
22 \text {. T. } 5 \mathrm{~S} \text {., R. } 24 \mathrm{~W} \text {. Bowser Formation } 60-110 \mathrm{ft} \\
\text { below top and } 1,650-1,700 \mathrm{ft} \text { above base. }\end{array}$ \\
\hline 52 & 22538 & $50 A H$ i $5 \mathrm{a}$ & $\begin{array}{l}\text { David Hill, 1950. Iniskin Peninsula. Iliamna } \\
\text { ( } \mathrm{C}-1) \text { quad. Same location as Mesozoic loc. } 22536 \text {, } \\
\text { but about } 100 \mathrm{ft} \text { lower stratigraphically. }\end{array}$ \\
\hline 53 & 22553 & 50AHi6 & 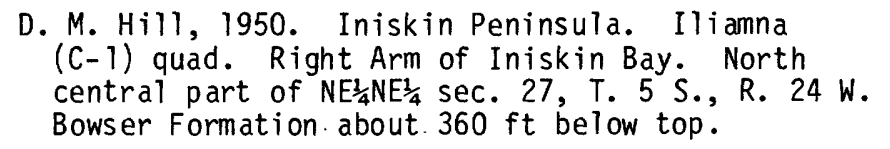 \\
\hline 54 & 20736 & 46 AMd 32 & $\begin{array}{l}\text { J. P. Minard, 1946. Iniskin Peninsula. Iliamna } \\
\text { (C-1) quad. East-central part of } N E \frac{1}{4} \mathrm{sec} .28 \text {, T. } \\
5 \mathrm{~S} ., \text { R. } 24 \mathrm{~W} \text {. Bowser Formation } 500-600 \mathrm{ft} \text { above } \\
\text { base and } 1,160-1,260 \mathrm{ft} \text { below top. }\end{array}$ \\
\hline 55 & 20739 & 46 AKr 134 & 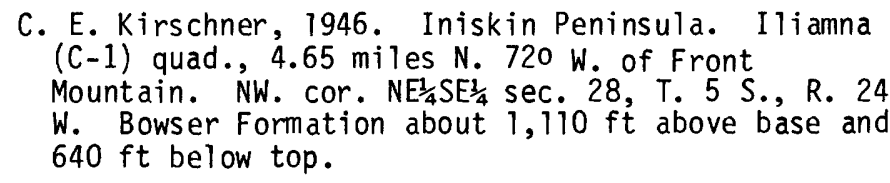 \\
\hline 56 & 3038 & $933 b$ & $\begin{array}{l}\text { T. W. Stanton and G. C. Martin, 1904. Iniskin } \\
\text { Peninsula. Iliamna (C-2) quad., } 5.25 \text { miles } \mathrm{N} \text {. } \\
740 \mathrm{~W} \text {. of Front Mountain. Shore of Iniskin Bay } \\
\text { at entrance to Right Arm. Probably south-central } \\
\text { part NW/4 sec. } 28, \mathrm{~T} \text {. } 5 \mathrm{~S} \text {., R. } 24 \text { W. Bowser } \\
\text { Formation, probably from middle part. }\end{array}$ \\
\hline 57 & 20764 & 46 AKr 187 & 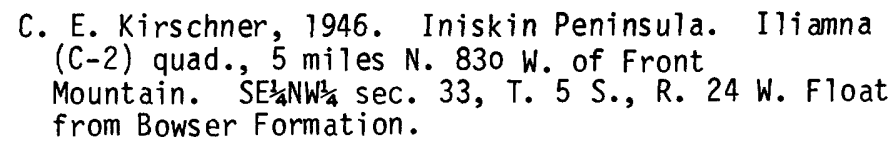 \\
\hline 58 & 22416 & $50 \mathrm{AHa} 10$ & 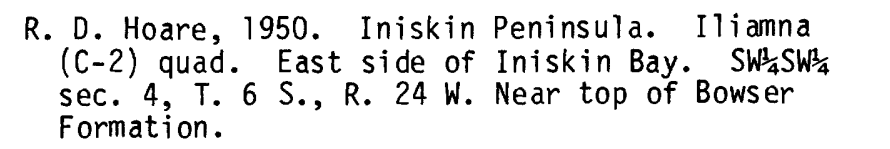 \\
\hline
\end{tabular}

cf. Cadomites deslongchampi (d'Orbigny). Sturani, 1964, Univ. Padova Ist. Geolgia Mineralogia Mem., v. 24, p. 19, 20, pl. 2, fig. $7 \mathrm{a}, \mathrm{b} ; 1966$, Soc. Paleont. Italiano Boll., v. 5, p. 28, pl. 6, fig. 1. cf. Cadomites deslongchampsi (d'Orbigny). Hahn, 1971, Geol. Jahrb. Landesamt Baden-Württemberg, v. 13, Abt. 13, pl. 9, fig. 16.

This species in the Talkeetna Mountains is represented by three specimens of which the smallest is attached to an umbilical plug of a much larger specimen that is septate except for its outermost half whorl. The third specimen consists of the adoral part of an adult body chamber. In addition, the species may be represented by one laterally crushed external mold from the Wrangell Mountains. 
These specimens have a coronate whorl section and a broad, flattened venter. Their primary ribs are sharp, fairly widely spaced; they become less widely spaced during growth, curve gently forward on the umbilical wall, and generally terminate in prominent nodes. The secondary ribs on the septate whorls are fine, closely spaced and average about four for each primary rib, but one of these four may arise freely between nodes instead of being attached to a node. Adorally on the body chamber the secondary ribs become fewer with respect to the primary ribs, and near the aperture number only two for each primary rib. The nodes also become variable in strength adorally on the body chamber.

The adoral end of the body chamber is imperfectly preserved but is marked by two single ribs that are separated and followed by broad shallow furrows.

On the largest septate specimen at a diameter of about $55 \mathrm{~mm}$, the whorl height is $21 \mathrm{~mm}$ and the whorl thickness is $35 \mathrm{~mm}$. The ratio of whorl height to thickness is about 60 percent, both on the septate whorl and on the adult body chamber.

These Alaskan specimens of Cadomites are similar to C. deslongchampsi (d'Orbigny) in whorl shape and ribbing. They differ mainly by having sparser ribbing on their adult body chamber. That species in Europe ranges from the highest Bajocian zone of Parkinsonia parkinsoni into the lowest Bathonian Zigzagiceras zigzag zone (Westermann and Rioult, 1975, p. 876) and probably is most common in the highest Bajocian (Hahn, 1971, p. 111; Kopik, 1974, p. 19).

Figured specimens.-USNM 240712-240715.

Occurrence.-Unnamed beds in the Talkeetna Mountains at USGS Mesozoic localities 30277, 30576, 30577 (contains part of same ammonite as at locality 30277 ). Nizina Mountain Formation in the Wrangell Mountains at Mesozoic locality 28682.

\section{Cadomites cf. C. rectelobatus (v. Hauer)}

Plate 4, figure 3

One external mold of an outer whorl bears somewhat denser secondary ribs than the specimens herein compared with $C$. deslongchampsi (d'Orbigny) and is more similar in that respect to forms illustrated as $C$. rectelobatus (v. Hauer) by Sturani (1964, p. 22, pl. 2, figs. 6, 8; 1966 , p. 29, pl. 13, figs. 1a, b); as C. daubenyi (Gemmellaro) in Buckman (1922, pl. 311); and as C. rectelobatus (v. Hauer) in Hahn (1971, p. 112, pl. 9, fig. 9a, b). It also resembles $C$. exstinctus (Quenstedt) (1887, p. 630, pl. 74, figs. 30, 32-34; Hahn, 1971, p. 110, pl. 9, figs. 1013) in density of ribbing.

Of these species, $C$. exstinctus is reported to range from the uppermost upper Bajocian zone of Parkinsonia parkinsoni into the lower part of the lower Bathonian zone of Zigzagiceras zigzag (Hahn, 1971, p. 59, 111) and is most common in the lower Bathonian. C. rectelobatus ranges from the uppermost Bajocian through most of the Bathonian but is most common in the lower Bathonian (Arkell, 1958, p. 232; Sturani, 1966, p. 29; Kopik, 1974, p. 21, 22).

Figured specimen.-USNM 240716.

Occurrence.-Nizina Mountain Formation at USGS Mesozoic locality 28682 in the Wrangell Mountains.

\section{Family MACROCEPHALITIDAE Buckman, 1922 Genus XENOCEPHALITES Spath, 1928 \\ Xenocephalites cf. $X$. hebetus Imlay Plate 2, figures 1-9}

Four specimens from the Bowser Formation bear ribbing that is nearly identical with that on the type specimens of $X$. hebetus Imlay (1953, p. 78, pl. 29, figs. 6-8, 11) from the Chinitna Formation of southern Alaska. They differ mainly by having moderately compressed to stout rather than globose whorls. Also, the body chamber, represented by at least three-fourths of a whorl, does not develop quite as strong ribbing. On the largest fragment of a body chamber (pl. 2, figs. 8, 9) the whorl section is broad and depressed, the ribbing high, sharp, and sparse, and the body chamber itself is markedly retracted from the inner tightly coiled septate whorls. These features are all similar to those on the adoral part of the body chamber of $X$. hebetus Imlay $(1953$, pl. 29, figs. 6, 7) and on the South American species, X. neuquensis (Stehn) (1924, p. 86, text fig. 11 on p. 87 , pl. 1 , fig. 3).

Figured specimens.-USNM 240717-240720.

Occurrences.-Bowser Formation, upper part, at USGS Mesozoic localities 21312, 22436, and 22713 west of Cook Inlet.

\section{Genus CHINITNITES Imlay, 1975}

Chinitnites parviformis (Imlay)

Kheraiceras? parviforme Imlay, 1953, U.S. Geol. Survey Prof. Paper 249-B, p. 82, pl. 33, figs. 3, 6, 8-10, 12.

Chinitnites parviformis (Imlay), 1975, U.S. Geol. Survey Prof. Paper 836 , p. 23 , pl. 3 , figs. $1,2,5-7$.

This species is represented in the Bowser Formation by five specimens whose characteristics have been summarized recently (Imlay, 1975, p. 23).

Types.-Holotype, USNM 108052; paratypes, USNM 108053a-c; hypotypes, USNM 180734 and 180735.

Occurrences. - Bowser Formation, upper part at USGS Mesozoic localities 11038, 11042, and 22436. Chinitna Formation, lower part at Mesozoic localities 21334 and 22427. 
Family KOSMOCERATIDAE Haug, 1887 Genus KEPPLERITES Neumayr and Uhlig, 1892

\author{
Kepplerites sp. A \\ Plate 1, figures 1, 2, 4, 5
}

cf. Kepplerites tychonis Ravn, Imlay, 1953, U.S. Geol. Survey Prof. Paper 249-B, p. 96, pl. 48, figs. 14-17.

cf. Kepplerites chisikensis Imlay, 1975, U.S. Geol. Survey Prof. Paper 836 , p. 15 , pl. 1, figs. $1-5$.

This species is represented by two fragmentary immature, septate specimens. The smallest specimen is undeformed and consists of two whorls. Of these, the innermost whorl at a diameter of $15 \mathrm{~mm}$ has a round whorl section that is as wide as it is high, a nearly evenly rounded venter that is not distinctly flattened, and a low vertical umbilical wall that rounds evenly into the flanks. Its primary ribs are moderately low, trend radially on the umbilical wall, curve strongly forward on the lower fifth of the flanks and then pass into two or three weaker flexuous secondary ribs. Between rib bundles occur one or two secondary ribs that arise freely low on the flanks. All secondary ribs incline gently forward on the flanks, arch forward on the venter, and are strongest on the venter.

The next larger whorl of the smallest specimen has a whorl height of $21 \mathrm{~mm}$, an estimated diameter of $18 \mathrm{~mm}$, and an umbilical width of $5 \mathrm{~mm}$. Its umbilical wall is fairly low, vertical, and rounds rather abruptly into the flanks. Its flanks are flattened below and round evenly above into a moderately broad rounded venter. Its primary ribs are weak on the umbilical wall but become higher and sharper ventrally. They curve backward on the umbilical wall, curve sharply forward low on the flanks, and pass into two to three somewhat weaker secondary ribs at about one-third of the height of the flanks. Other secondary ribs arise near the zone of furcation on the flanks, resulting in three to four secondary ribs for each primary rib. All secondary ribs incline forward on the flanks and become slightly stronger ventrally.

The largest fragment is much worn and represents a slightly later growth stage than shown on the small specimen just described. Most of it appears, however, to be essentially identical in umbilical width, flank shape, and rib characteristics. The adoral fifth of the specimen is nonseptate, retains very little shell material, is broken ventrally and bears long, weak primary ribs. Secondary ribs are barely visible at only one place.

This species, once compared with a finely ribbed species of Kepplerites from Greenland (Imlay, 1962a, p. C3; Ravn, 1911, p. 490, pl. 37, fig. 1), differs from most described species of Kepplerites by lacking a distinctly flattened venter. On the smallest specimen, however, the ventral ribs form a pattern suggestive of incipient flattening. Also, the species greatly resembles $K$. chisikensis Imlay (1975, pl. 1, figs. 1-5), which occurs near the base of the Chinitna and Shelikof Formations, except for the absence of tubercles even on its inner whorls.

Figured specimens.-USNM 180716 and 240721.

Occurrence.-Bowser Formation at USGS Mesozoic locality 21319 . The specimens were collected about 420 feet below the top of the formation and 810 feet above the uppermost occurrence of Cranocephalites (Mesozoic locality 20751).

\section{Kepplerites sp. B. \\ Plate 3, figure 9}

This species is represented near the top of the Bowser Formation by one specimen that has a moderately stout adult body chamber and the crushed adoral end of the outermost septate whorl. The body chamber occupies half a whorl, terminates adorally in a broad, shallow, forwardly inclined constriction; has an ovate whorl section that is slightly wider than high; and retracts markedly from the inner septate whorls.

The ribbing on the flanks of the septate whorl is fine and dense. On the body chamber the primary ribs are narrow, incline slightly adapically on the umbilical wall, incline adorally on the lower third of the flanks, and terminate ventrally in weak tubercles from which pass bundles of three to four much weaker secondary ribs. Other ribs arise freely along the zone of tuberculation, resulting in the presence of four secondary ribs for each primary rib. All secondary ribs incline slightly adorally on the flanks and are eroded on the venter.

The body whorl of this species bears a general resemblance to that of Kepplerites mcevoyi (McLearn) (1928, p. 20 , pl. 4, figs. 1, 2; Imlay, 1953, p. 97, pl. 51, figs. 3, $5-8$ ) but has much weaker tubercles, fewer secondary ribs, and a more strongly retracted body chamber. $K$. multus (McLearn) (1929, p. 7, pl. 3, fig. 2) has a more inflated whorl section, a higher umbilical wall, and stronger tubercles. $K$. chisikensis Imlay (1975, p. 15, pl. 1, figs. 1-5) has a more compressed whorl section, finer, denser ribbing, and much weaker tubercles.

\section{Figured specimen.-USNM 240722.}

Occurrence.-Bowser Formation, 50-70 feet below top at USGS Mesozoic locality 30258 south of Tuxedni Bay.

\section{Kepplerites sp. C. \\ Plate 1, figure 3}

One nucleus of Kepplerites from the Bowser Formation has more evolute coiling and stronger ribbing than other specimens of Kepplerites found in that formation. It bears some resemblance to the innermost known whorls 
of $K$. gitinsi (McLearn) as figured by Imlay (1953, pl. 52, figs. 1, 2).

Figured specimen.-USNM 240723.

Occurrence.-Bowser Formation, upper part, about 100 feet below top, at USGS Mesozoic locality 30263 south of Tuxedni Bay.

\section{Family CARDIOCERATIDAE Siemiradzki, 1891 Subfamily CADOCERATINAE Hyatt, 1900 Genus CRANOCEPHALITES Spath, 1932 \\ Cranocephalites costidensus (Imlay) Plate 7, figures 1-12}

Arctocephalites (Cranocephalites) costidensus Imlay, 1962a, U.S. Geol. Survey Prof. Paper 374-C, p. C-24, pl. 2, figs. 11-19.

Arctocephalites (Cranocephalites) costidensus Imlay. Frebold and Tipper, 1973, Canadian Jour. Earth Sci., v. 10, no. 7, p. 1115, pl. 2, fig. 2; pl. 4, fig. 2-7.

This species is represented in the U.S. Geological Survey collections by 108 specimens of which 15 are from west of Cook Inlet, 85 from the Talkeetna Mountains, and 8 from the Wrangell Mountains. It is characterized by having fine dense ribbing on its septate whorls and on most body chambers such as on the holotype (Imlay, 1962a, pl. 2, figs. 14, 15). Some moderately stout to stout specimens (pl. 7, figs, 5, 8, 11; Imlay, 1962a, pl. 2, fig. 19) have somewhat coarser ribs on their adult body chambers than those found on most specimens of the species.

Types.-Holotype, USNM 130745; paratypes, USNM 130746, 130748, and 130749; hypotypes, USNM 240724 240728.

Occurrences.-Bowser Formation west of Cook Inlet at USGS Mesozoic localities 20754, 21283, 22698, and 22712 and probably at Mesozoic localities 20736 and 20754. Unnamed beds in the Talkeetna Mountains at Mesozoic localities 8573, 24117, 27515, 30271, 30273, 30276-30278, $30286-30290$, and $30575-30579$ and probably at Mesozoic localities 24822, 24825, 30279, and 30292. Nizina Mountain Formation in the Wrangell Mountains at $\mathrm{Me}$ sozoic localities 28681 and 28682 , and probably at $\mathrm{Me}$ sozoic localities 28525 and 28699.

\section{Cranocephalites alaskanus Imlay n. sp. \\ Plate 5, figure 1-5}

Arctocephalites (Cranocephalites) pompeckji (Madsen) of Imlay, 1962a, U.S. Geol. Survey Prof. Paper 374-C, p. C-23, pl. 1, figs. 4, 6, 8, 10 (not figs. 7, 9, 11-12).

Associated with Cranocephalites costidensus (Imlay) (1962a, p. C-24, pl. 2, figs. 11-19) in southern Alaska is a much less common species that has much higher and sparser ribs and fewer secondary ribs per primary rib. This species was formerly identified by Imlay (1962a, p. C-23) as C. pompeckji (Madsen) (1904, p. 189, pl. 8, figs. 5, 6a, b; Spath, 1932, p. 16, pl. 4, figs. 8-10, pl. 5, figs. 6-8, pl. 13, figs. 1a, b; Donovan, 1953, p. 83, pl. 17, figs. 2a, b, 3a, b). It differs, however, by having finer denser ribs on its septate whorls; lower, blunter, and sparser ribs on its adult body chamber; and by attaining a much smaller adult size. In these respects it is intermediate between $C$. pompeckji (Madsen) and $C$. indistinctus Callomon (1959, p. 510, pl. 17, figs. 3, 4, pl. 18, figs. 1, 2) from East Greenland.

Types.-Holotype, USNM 240729; paratypes, USNM 130752 and 130753.

Occurrences.-Bowser Formation, lower two-fifths, west of Cook Inlet at USGS Mesozoic localities 21283 and 22698 and possibly at Mesozoic localities 20754, 21309, 22711, and 22712. Nizina Mountain Formation in the Wrangell Mountains at Mesozoic locality 28682 and possibly at Mesozoic localities 28525, 28527, 28681, and 28698.

\section{Cranocephalites cf. C. ignekensis Imlay \\ Plate 5, figures 9-11}

Arctocephalites (Cranocephalites) pompeckji (Madsen) of Imlay, 1962a, U.S. Geol. Survey Prof. Paper 347-C, p. C-23, pl. 1, figs. 1, 11-13 (not figs. 5-8, 10).

cf. Cranocephalites ignekensis Imlay, 1976, U.S. Geol. Survey Prof. Paper 854, p. 15, 16, pl. 2, figs. 1-9, 11, 12.

In southern Alaska only two ammonites similar to $C$. pompeckji (Madsen) have been found above the range of C. costidensus (Imlay). One of these (pl. 5, fig. 9), an external mold of the adoral part of a body chamber, bears coarse, fairly broad, forwardly inclined ribs of which about half bifurcate fairly low on the flanks and all cross the venter transversely without diminution in strength. The other specimen (pl. 5, figs. 10, 11; Imlay, 1962a, pl. 1 , figs. 9, 11-13) has identical coarse ribbing on its body chamber. It differs from some specimens, herein described as $C$. alaskanus Imlay n. sp., by attaining a larger adult size and by having slightly coarser ribbing on its adult body chamber. Compared with the holotype of C. pompeckji (Madsen, 1904, pl. 8, figs. 6a, b), it appears to have finer ribbing on the septate part of the adult body whorl, blunter ribbing on the nonseptate part, and a less strongly retracted body chamber.

These two specimens from southern Alaska are likewise similar to Cranocephalites ignekensis Imlay (1976, pl. 2, figs. 1-9, 11, 12) that occurs in northern Alaska just below beds containing Arctocephalites. They differ mainly by attaining a larger adult size, by having blunter and sparser ribbing on the adult body chamber, and by having a slightly more complicated suture line. They may be within the range of variation of that species.

Figured specimens.- USNM 130751 and 240730.

Occurrences.-Bowser Formation, near base of upper fourth, west of Cook Inlet at USGS Mesozoic locality 
21284. Unnamed beds in the Talkeetna Mountains at Mesozoic locality 30275.

\section{Cranocephalites globosus Imlay n. sp. \\ Plate 6, figures $1-3,5,6,8-13$}

This species is represented by three specimens. It is characterized by a globose form; by much depressed whorls that are widest at about one-fourth of their height; by fairly coarse ribbing on its smallest whorls; by fine, sharp, fairly dense ribbing on its outer whorls; by a very narrow, funnel-shaped umbilicus on its septate whorls; and by a scaphitoid body chamber. Its umbilical wall is vertical basally but rounds fairly evenly into the flanks. Its adult body chamber represents about three-fifths of a whorl. The aperture is marked by a constriction that is followed by a swelling.

On septate whorls the primary ribs trend nearly radially and divide at about the top of the lower fourth of the flanks into two or three much weaker secondary ribs that cross the venter transversely or with a slight forward arching. Other secondary ribs arise freely near the zone of furcation, resulting in about three secondary ribs for each primary.

No ribbing is preserved on the adapical part of the body whorl. Near the aperture, however, are found several strong widely spaced primary ribs that are most prominent where the whorl section is widest and that fade out gradually ventrally. The midventral area near the aperture bears several patches of smooth shelly material.

This species resembles Cranocephalites costidensus (Imlay) (1962a, p. C-24, pl. 2, figs. 11-19) in the fineness of ribbing on its outer whorls. It differs, however, by being much more globose and by certain features of its primary ribs. Those ribs fork much lower on the flanks, are stronger relative to the secondary ribs, and are much more prominent near the adult aperture. Arctocephalites orientalis Krimholz (1939, p. 32, 59, pl. 2, figs. 5, 6) has similar fine ribbing but has a more compressed whorl section that is widest at about half of the whorl height.

Types.-Holotype, USNM 240731; paratypes, USNM 240732 and 240733.

Occurrence.-Bowser Formation, 620 feet above base, at USGS Mesozoic locality 20751 on the Iniskin Peninsula; unnamed beds in the Talkeetna Mountains at Mesozoic localities 24116 and 24117.

\section{Cranocephalites cf. C. vulgaris Spath}

Plate 3, figures $7,8,10,11$

This species is represented by one undeformed internal mold of an adult body whorl. It has a compressed whorl section, a highly arched venter, flattened flanks, a low nearly vertical umbilical wall that rounds rather abruptly into the flanks, and a contracted body chamber that occupies three-fifths of a whorl and is terminated by a shallow constriction.

The ribs on the septate part of the body whorl are sharp and fairly closely spaced. The primary ribs trend backward on the umbilical wall, curve forward on the lower third of the flanks, and give rise to pairs of slightly weaker secondary ribs. These secondary ribs incline forward on the flanks but cross the venter transversely.

On the body chamber are found long simple ribs that either bifurcate at about the top of the lower third of the flanks or alternate with one of two short intercalated ribs. The simple ribs on the lower third of the flanks are sharp, widely spaced, curve adapically at the umbilical edge, and curve adorally rather strongly on the flanks. All ribs incline forward on the upper two-thirds of the flanks, cross the venter transversely, become weaker and broader above the middle of the flanks, and almost fade out on the venter. This reduction in strength does not appear to be due to weathering or abrasion.

The specimen, at an estimated maximum diameter of $90 \mathrm{~mm}$, has a whorl height of $37 \mathrm{~mm}$, a whorl thickness of $33 \mathrm{~mm}$, and an umbilical width of $20 \mathrm{~mm}$. About onethird of a whorl adapically, the same dimensions are 72, 32,28 , and $13 \mathrm{~mm}$.

This species is characterized by its compressed shape, by the presence of fine, sharp ribs on the septate part of the shell, and by the faintness of all ribs on the venter of the adult body chamber. The last feature distinguishes it from all other known species of Cranocephalites in Alaska but is fairly common in species of that genus in the Arctic region (Spath, 1932, p. 14; Voronets, 1962, pls. 5, 6). For example, the Alaskan species under discussion matches fairly well a compressed variant of $C$. vulgaris Spath (1932, pl. 5, figs. 1a, b) from East Greenland except for having somewhat weaker ribbing. It also greatly resembles the holotype of $C$. vulgaris Spath (1932, pl. 1, figs. $4 a, b)$ except for being more compressed.

Figured specimen.-USNM 240734.

Occurrence.-Unnamed beds in the Talkeetna Mountains at USGS Mesozoic locality 30275.

\section{Cranocephalites sp. A. \\ Plate 5, figures 6-8}

One worn adult specimen differs from the specimen herein figured (pl. 3, figs. 7, 8, 10,11) as C. cf. C. vulgaris Spath by having a stouter whorl section and somewhat stronger primary ribs and by its secondary ribs arching adorally on the venter near the aperture.

Figured specimen.-USNM 240735.

Occurrence.-Bowser Formation at USGS Mesozoic locality 22436 on the Iniskin Peninsula. 
Cranocephalites sp. B.

Plate 6, figures 4, 7

One undeformed body whorl shows most of the septate part and a little of the adoral end of the body chamber. This whorl is ovate and slightly wider than it is high. Its aperture is marked on the flanks by a deep constriction. Its umbilicus is extremely narrow but widens appreciably near the aperture as the body chamber contracts. Apparently the body chamber occupies about half a whorl.

The ribbing on the septate part of the shell is sharp and moderately spaced. Its primary ribs trend radially and divide at one-fourth to one-third of the height of the flanks into two or three slightly weaker secondary ribs. A few secondary ribs arise freely between the forked ribs. All secondary ribs incline adorally on the flanks and then cross the venter transversely.

The ribbing near the aperture consists only of faint, broad, primary ribs and even fainter secondary ribs that are barely visible on the venter.

This Alaska specimen was obtained at nearly the same stratigraphic position as a specimen herein described as Cranocephalites cf. C. ignekensis Imlay that was colleeted nearby on another tributary of Bear Creek. It differs, however, by being smaller and more robust, by having more secondary ribs per primary rib, and by its ribbing becoming faint near the aperture. These features match much better those of some robust specimens of $C$. vulgaris Spath (1932, p. 1, figs. 3a, b, 4a, b, pl. 4, figs. $3 \mathrm{a}, \mathrm{b}$, pl. 8, figs. 1a, b) from East Greenland.

Figured specimen.-USNM 240736.

Occurrence.-Bowser Formation, 300 feet below top at USGS Mesozoic locality 30257 near Tuxedni Bay.

\section{Genus ARCTOCEPHALITES Spath, 1928 \\ Arctocephalites cf. A. elegans Spath}

Plate 8, figures $18-21$

Arctocephalites is represented in southern Alaska by one ammonite that consists of a fairly complete septate finely ribbed whorl and about one-third of a nonseptate nearly smooth outer whorl.

The septate whorl has a fairly narrow umbilicus, a subquadrate whorl section that is as wide as it is high, and fine, rather closely spaced ribs that incline strongly forward on the lower half of the flanks but cross the venter transversely. The primary ribs trend radially on the umbilical wall, curve forward low on the flanks and divide into two or three slightly weaker secondary ribs at about the top of the lower fourth of the flanks. Other ribs arise freely along the zone of furcation, resulting in about three secondary ribs for each primary rib.

The nonseptate whorl is fragmentary and worn, and its junction with the septate whorl is not preserved by half a whorl. Its surface, exposed at several places, is nearly smooth except for the presence of a few weak primary ribs low on the flanks.

This ammonite shows considerable resemblance to some ammonites from northern Canada that have been assigned to Arctocephalites elegans Spath by Frebold (1961, p. 10,11 , pls. $9-11$ in part; 1964 , p. 3 , pls. 1 and 2 in part). The ribbing on its septate whorl appears to be slightly finer and denser than on most of the Canadian specimens but matches fairly well with that on the adapical end of one specimen (Frebold, 1961, pl. XI, figs. 1a, b). The smoothness of its outer whorl matches very well with that of the body whorl of $A$. elegans Spath. The presence of weak primary ribs on the flanks of the nonseptate whorl suggest that the fragment is the adapical part of the adult body chamber of Arctocephalites. It appears, therefore, that the ammonite from west of Cook Inlet is either a finely ribbed variant of $A$. elegans Spath as defined by Frebold (1961, p. 11) or a closely related species. This is borne out by comparisons with a specimen of $A$. cf. A. elegans Spath from northern Alaska (Imlay, 1976, p. 16, pl. 4, figs. 1-3).

Figured specimen.-USNM 180743.

Occurrence.-Bowser Formation, upper part, at USGS Mesozoic locality 22699 west of Cook Inlet. The specimen was collected $360-380$ feet below the top of the formation, 170-190 feet below an occurrence of Iniskinites (Mesozoic loc. 22700) and about 850 feet above Cranocephalites costidensus (Imlay) (Mesozoic loc. 22698).

\section{Genus TUXEDNITES Imlay n. gen.}

Tuxednites is characterized by fairly small, moderately compressed to stout shells; a fairly small umbilicus that does not become wider on the body whorl; an adult body chamber that occupies about three-fourths of a whorl; an apertural constriction that is conspicuous only low on the flanks; and high, sharp, gently flexuous ribs that cross the venter transversely. The primary ribs become high on the lower fourth of the flanks where most of them pass into pairs of weaker secondary ribs that become high and sharp on the venter. The suture line is poorly preserved and cannot be traced accurately. Tuxednites alticostatus (Imlay), described previously as Arctocephalites? alticostatus Imlay (1962a, p. C-22), is designated as the type species.

Tuxednites differs from Chinitnites (Imlay, 1975, p. $17,18)$ by its septate whorls having stronger primary ribs and a slightly wider umbilicus and by its adult body whorl not contracting from the septate whorls.

\section{Tuxednites alticostatus (Imlay) \\ Plate 8, figures 1-9}

Arctocephalites? alticostatus Imlay. 1962a, U.S. Geol. Survey Prof. Paper 374-C, p. C-22, pl. 2, figs. 1, 2, 4-8 [not fig. 3].

This species is represented by 18 specimens that vary considerably in coarseness of ribbing and in stoutness in 
ways similar to that shown by Chinitnites chinitnaensis Imlay (1975, p. 22, pl. 2). It does not include a specimen from USGS Mesozoic locality 24116, referred to previously (Imlay, 1962a, p. C-23), which may represent the inner whorls of Cranocephalites globosus Imlay n. sp. from the same locality. Similarly the small specimen from USGS Mesozoic locality 21308 (see Imlay, 1962a, pl. 2, fig. 3) may represent the inner whorls of a globose form of Cranocephalites. The other specimens of T. alticostatus (Imlay) that were previously illustrated are all stout to fairly stout, are coarsely ribbed, and are representative of 13 of the 18 specimens herein assigned to the species. The other five specimens, present only at USGS Mesozoic localities 20746 and 30290 , differ only by being a little less stout and a little finer ribbed. (See pl. 8 , figs. 3,4 .)

The species is possibly also represented by an even more finely ribbed, more compressed specimen that was once illustrated (Imlay, 1962a, pl. 1, fig. 7) as Arctocephalites (Cranocephalites) pompeckji (Madsen). That specimen, refigured herein on plate 8 , figures 16,17 , is considerably finer ribbed and more compressed than the holotype of Tuxednites alticostatus (Imlay), with which it is associated at USGS Mesozoic locality 22698, but is only a little finer ribbed than some specimens that are herein assigned to that species (compare pl. 8, figs. 3, 4).

Types.-Holotype, USNM 103757; paratypes, USNM 103758 and 103759; hypotypes, 240737-240739.

Occurrence.-Bowser Formation, lower part at USGS Mesozoic localities 11038, 20011, 20746, 20752, and 22698 west of Cook Inlet; at Mesozoic localities 30288 and 30290 in the Talkeetna Mountains, and at Mesozoic locality 28682 in the Wrangell Mountains. This species ranges from the upper part of the beds characterized by Cranocephalites costidensus through the overlying beds containing other species of Cranocephalites into the lower part of the range of Chinitnites parviformis (Imlay) at USGS Mesozoic localities 11038 and 20746.

\section{Tuxednites? sp. ind.}

Plate 8, figures 10-15

Tuxednites is possibly represented by a number of small globose narrowly umbilicate sharply ribbed immature ammonites that occur in the beds characterized by Cranocephalites costidensus (Imlay). These ammonites show some resemblance to Xenocephalites but differ by having a wider umbilicus and much stronger, sharper ribs on their septate whorls. They show more resemblance to Tuxednites alticostatus (Imlay) (1962a, p. C22, pl. 2, figs. 3-8) in coiling and in rib plan but differ by being much stouter and by having sparser, stronger, less flexuous ribs. Their features suggest that they belong to Tuxednites, but their preservation does not permit a definite taxonomic assignment. Also, the fact that none of the specimens bears an apertural constriction suggests that all of the specimens may be immature forms and, therefore, could represent the early growth stages of much larger ammonites such as Cranocephalites globosus Imlay $\mathrm{n}$. sp., as described herein.

Figured specimens.-USNM 240741 and 240742.

Occurrence.-Bowser Formation, lower part at USGS Mesozoic localities 20005, 20744, and 30265 west of Cook Inlet; at Mesozoic locality 24116 in the Talkeetna Mountains; and at Mesozoic locality 28682 in the Wrangell Mountains.

\section{Genus INISKINITES Imlay, 1975 \\ Iniskinites cf. I. intermedius (Imlay) \\ Plate 8, figures 22, 26-28}

cf. Kheraiceras intermedium Imlay, 1953, U.S. Geol. Survey Prof. Paper 249-B, p. 81, pl. 31, figs. 1-4, pl. 32, figs. 2, 3, 5, 7, 8.

cf. Iniskinites intermedius (Imlay), 1975, U.S. Geol. Survey Prof. Paper 836, p. 24, pl. 3, figs. 3, 4.

Iniskinites intermedius (Imlay) is represented (1) at the very top of the Bowser Formation on Chisik Island by the holotype (Imlay, 1953, pl. 31, figs. 3, 4) at USGS Mesozoic locality 21272; (2) probably 240 feet below the top near Lake Hickerson (see pl. 8, fig. 26) at Mesozoic locality 22700; (3) probably 300 feet below the top (pl. 8, figs. 22, 27, 28) at Mesozoic locality 30262 on an unnamed creek east of Bear Creek south of Tuxedni Bay; and (4) probably about 540 feet below the top at Mesozoic locality 21313 on Park Creek near Chinitna Bay.

Types.-See listing in Imlay (1975, p. 24); figured specimens USNM 240743 and 240744.

\section{Iniskinites cf. I. magniformis (Imlay) \\ Plate 8, figures 23-25}

Two immature specimens of Iniskinites have very fine dense ribbing and a globose form as on the inner whorls of $I$. magniformis Imlay (1975, pl. 4, figs. 2,7$)$. The inner whorls of $I$. abruptus (Imlay) (1953, pl. 33, figs. 1, 7; 1975 , pl. 5, figs. 1, 2) have slightly coarser ribbing.

Figured specimen.-USNM 240745.

Occurrence.-Bowser Formation at USGS Mesozoic locality 22536 near Iniskin Bay on the Iniskin Peninsula.

\section{Genus TALKEETNITES Imlay n. gen.}

Talkeetnites is characterized by fairly large shells that change during growth from globose to cadicone; by a deep, rather narrow funnel-shaped umbilicus; by a slightly retracted body chamber; by a vertical umbilical wall that rounds evenly into the flanks; by its septate inner whorls bearing sharp ribs that bifurcate along the line of greatest whorl thickness and become sharper ventrally; by its outermost whorls bearing secondary ribs that weaken adorally and primary ribs that become stronger adorally; by the lack of tubercles on the septate whorls; and by the 
primary ribs becoming swollen and comma shaped on the body chamber. The suture line is poorly exposed.

Talkeetnites cadiformis Imlay, described herein, is designated as the type species.

Talkeetnites resembles cadicone species of Tulites and Cadoceras in the shape of its outer whorl. Its inner whorls differ from those of Tulites, however, by lacking a sharp or distinct umbilical edge, by not bearing nodes, and by bearing sharp ribs (compare Arkell, 1952, pl. 9, figs. 4a, b, 6a, b, pl. 11, figs. 6a-d; 1954, pl. 12, figs. 2a, b, 4a, b, pl. 13, figs. 6a, b). Its body whorl differs from that of Cadoceras by lacking a distinct umbilical edge and by contracting from the septate whorls. Its small inner whorls are more tightly coiled than in Cadoceras but are comparable in that respect with those of Cranocephalites with which they are associated. Overall the genus appears to be more closely related to Cranocephalites than to Cadoceras or Tulites.

\section{Talkeetnites cadiformus Imlay n. sp. \\ Plate 9, figures 1-10}

This species is represented by two specimens whose outer whorls are extremely wide and depressed (cadicone) and whose inner whorls are globose. Umbilicus deep, moderately narrow, funnel shaped. Umbilical wall, vertical at base, gently inclined above, rounding evenly into flanks on all whorls but becoming more narrowly rounded on body whorl. Body chamber incompletely preserved, but occupies at least three-fifths of a whorl on the largest specimen, and its adoral part is slightly retracted from the septate whorls. Aperture unknown.

On the smallest preserved whorls, the ribs are sharp, high, moderately spaced, and gently flexuous. Primary ribs trend nearly radially on the umbilical wall and generally bifurcate along the line of greatest whorl thickness. Secondary ribs are slightly sharper than the primary ribs, curve forward on the flanks, and then cross the venter transversely or with a slight forward arching.

Adorally on the penultimate and body whorls, the secondary ribs gradually become weaker on the venter but persist to the end of the largest specimen and arch forward considerably on the body chamber. The primary ribs, by contrast, gradually become stronger adorally along the line of greatest whorl thickness, and near the adoral end of the body chamber develop into commashaped swellings from which pass broad faint secondary ribs.

The dimensions of the holotype, in millimeters, and ratios of the diameter are as follows:

\begin{tabular}{|c|c|c|c|}
\hline Diameter & $\begin{array}{c}\text { Whor } 1 \\
\text { height }\end{array}$ & $\begin{array}{l}\text { Whor 1 } \\
\text { thickness }\end{array}$ & $\begin{array}{l}\text { Umbilical } \\
\text { width }\end{array}$ \\
\hline 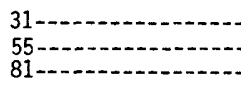 & $\begin{array}{l}15(0.48) \\
23(.42) \\
32(.39)\end{array}$ & 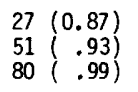 & $\begin{array}{r}6.5(0.21) \\
10.0(.18) \\
25.0(.31)\end{array}$ \\
\hline
\end{tabular}

The suture line cannot be traced.

Types.-Holotype, USNM 240746; paratype, USNM 240747.

Occurrence.-Unnamed beds in the Talkeetna Mountains at USGS Mesozoic locality 30277.

\author{
Family REINECKEIIDAE Hyatt, 1900 \\ Genus PARAREINECKEIA Imlay, 1962 \\ Parareineckeia hickersonensis Imlay \\ Plate 10, figures 1-10
}

Parareineckeia hickersonensis Imlay, 1962a, U.S. Geol. Survey Prof. Paper 374-C, p. C-25, pl. 7, figs. 1-5.

?Parareineckeia cf. $P$. hickersonensis Imlay. Frebold and Tipper, 1973, Canadian Jour. Earth Sci., v. 10, p. 1119, pl. 6, fig. 6.

This species, in addition to the holotype from the Lake Hickerson area west of Cook Inlet, is represented by 4 septate and 1 adult specimen (microconch) from the Talkeetna Mountains and 22 fragmentary, compressed specimens from the Wrangell Mountains. These show that the rib pattern as preserved on the holotype gradually becomes stronger during further growth. On the largest specimen available (pl. 10, fig. 10), the body chamber occupies three-fifths of a whorl and terminates simply. On one of the small specimens (pl. 10, fig. 3), some tubercles form the base of prominent spines that project ventrally.

Types.-Holotype, USNM 130756; hypotypes, USNM 240748-240752.

Occurrence.-Nizina Mountain Formation in the Wrangell Mountains at USGS Mesozoic localities 28524, 28681, 28682, 28696, 28698, and 28701. Unnamed beds in the Talkeetna Mountains at Mesozoic localities 30272, 30576, and 30577. Bowser Formation west of Cook Inlet at Mesozoic locality 22698.

Parareineckeia nelchinensis Imlay n. sp.

Plate 11, figures 1-16

Parareineckeia ef. P. shelikofana (Imlay), 1962a, U.S. Geol. Survey Prof. Paper 374-C, p. C-26, pl. 7, fig. 6, 7.

Parareineckeia cf. $P$. shelikofana (Imlay), Frebold and Tipper, 1973, Canadian Jour. Earth Sci., v. 10, p. 1117, pl. 4, fig. 1, pl. 6, figs. 3-5.

This species is represented by 30 specimens of which 4 are from the Talkeetna Mountains, 25 from the Wrangell Mountains, and 1 from the Iniskin Peninsula. These specimens, although most are crushed and fragmentary, do represent various growth stages including part of an adult body chamber. They show that the species is intermediate in characteristics between $P$. hickersonensis Imlay (1962a, p. C-25, pl. 7, figs. 1-5) and P. shelikofana (Imlay) (1953, p. 101, pl. 55, figs. 1, 8). It differs from $P$. hickersonensis Imlay by having considerably weaker and denser ribbing and a slightly higher whorl section. It differs from $P$. shelikofana (Imlay) by having slightly sparser and sharper ribs at comparable sizes and by its lateral tubercles persisting to a much later growth stage. 
Types.-Holotype, USNM 240753; paratypes, USNM 130750, 240754-240760.

Occurrences.-Nizina Mountain Formation in the Wrangell Mountains at USGS Mesozoic localities 28524, 28527, and 28681-28683. Unnamed beds in the Talkeetna Mountains at Mesozoic localities 24117, 30272, and 30276. Bowser Formation in the Iniskin Peninsula at Mesozoic locality 3038 and possibly at 20745 . The species is commonly associated with Cranocephalites costidensus (Imlay) and Parareineckeia hickersonensis Imlay. These occurrences, however, are much lower stratigraphically than those with $P$. shelikofana (Imlay, 1953, p. 101, 102).

\section{Family PERISPHINCTIDAE Steinmann, 1890 Subfamily LEPTOSPHINCTINAE Arkell, 1950 Genus COBBANITES Imlay, 1962}

Cobbanites talkeetnanus Imlay

Plate 12, figures 2-4, 7-9

Cobbanites talkeetnanus Imlay, 1962a, U.S. Geol. Survey Prof. Paper 374-C, p. C-27, pl. 7, figs. 8-13, pl. 8, fig. 1 .

Cobbanites talkeetnanus Imlay. Frebold and Tipper, 1973, Canadian Jour. Earth Sci., v. 10, no. 7, p. 1123, pl. 7, figs. 1-4.

This species is represented by 7 fairly well preserved specimens from the Talkeetna Mountains and 12 fragmentary septate specimens from the Wrangell Mountains. Its characteristic features, as shown on the original type specimens, are herein supplemented by views of inner septate whorls. Note particularly that on the smallest specimen (pl. 12, figs. 8,9) the primary ribs terminate ventrally in weak swellings and that the ribs are reduced in strength along the midline of the venter.

The outer septate whorl of this species bears considerable resemblance to that of Leptosphinctes (Vermisphinctes?) reparator Buckman (1923, p. 366), which Arkell (1958, p. 168) assigns to Prorsisphinctes, but is more compressed, more involute, and its ribs more widely spaced. The inner septate whorls of C. talkeetnanus Imlay in comparison with $L$. $(V$.) vermiformis Buckman $(1920$, pl. 162) are more involute and have sparser, weaker ribs that arch forward more strongly on the venter.

Types.-Holotype, USNM 130743; paratype, USNM 130744; hypotypes, USNM 240761-240763.

Occurrences.-Nizina Mountain Formation in the Wrangell Mountains at USGS Mesozoic localities 28525, 28682, and 28699; unnamed beds in the Talkeetna Mountains at Mesozoic localities 24116, 30277, 30574, and 30578.

\section{Cobbanites striatus Imlay n. sp. \\ Plate 12, figures $1,5,10,11$}

This species is represented by one moderately small septate specimen and by one smaller fragment. It is distinguished from $C$. talkeetnanus Imlay by having much finer, weaker, and denser ribbing and by its secondary ribs outnumbering the primary ribs about 3 to 1 instead of 2 to 1. On the adoral end of the largest preserved septate whorl the secondary ribs are only faintly connected with the primary ribs. This ribbing is appreciably finer and denser than in Leptosphinctes (Vermisphinctes) subdivisus Buckman (1920, pl. 190) from the upper Bajocian of England or on Cobbanites talkeetnanus var. densicostatus Frebold and Tipper (1973, p. 1125, pl. 7, figs. 5, 6) of British Columbia.

Holotype.-USNM 240764; paratype, UCLA 4988.

Occurrences. - Nizina Mountain Formation in the Wrangell Mountains at USGS Mesozoic localities 28682 and probably 28699; unnamed beds in the Talkeetna Mountains at Union Oil Co. locality RAL 65 in association with Cranocephalites costidensus (Imlay).

Cobbanites tuxedniensis Imlay n. sp.

Plate 12, figures $6,12-15$

This species is represented by one septate specimen that shows nearly five whorls at diameters between 12 and $112 \mathrm{~mm}$. Shell compressed and moderately involute. Whorls embrace from one-third to two-fifths of the preceding whorl and become more evolute and more compressed during growth. At the diameter of $56 \mathrm{~mm}$, the whorl section is subquadrate and $16 \mathrm{~mm}$ in height and width. Half a whorl adorally at a diameter of $78 \mathrm{~mm}$ the whorl section is $24 \mathrm{~mm}$ in height and $19 \mathrm{~mm}$ in width. Umbilicus very wide and shallow. Umbilical wall low and steeply inclined. Flanks gently convex on innermost exposed whorls but become nearly flat on outer septate whorls. Venter evenly rounded on inner whorls but becomes moderately arched on largest septate whorl.

The ornamentation, as exposed in the umbilicus, consists of stout radially trending primary ribs and some weak constrictions. These primary ribs are nearly as wide as the interspaces, thicken slightly ventrally, and are mostly not tuberculate, although most furcation points are hidden by the succeeding whorls.

On the outer two septate whorls the primary ribs likewise trend radially, become slightly weaker adorally, generally pass into pairs of slightly weaker secondary ribs at about three-fifths of the height of the flank, and are slightly swollen at the furcation points. Some secondary ribs arise freely on the flanks near the zone of furcation and others are indistinctly connected with the primary ribs. All secondary ribs arch forward moderately on the venter, but this arching becomes less pronounced during growth. Six weak to moderately strong constrictions occur on the outermost complete whorl. Slight reduction of ribbing along the midventral line is apparent at a few places.

The suture line, exposed only on the lower two-thirds of the flank, has long slender lobes similar to that on $\mathrm{Cob}$ banites talkeetnanus Imlay (1962a, pl. 7, fig. 8). 
This species is intermediate in most characteristics between Cobbanites talkeetnanus Imlay from Alaska (Imlay, 1962a, p. C-27, pl. 7, figs. 8-13) and $C$. aff. $C$. talkeetnanus Imlay from eastern Oregon (Imlay, 1964, p. D-16, pl. 4, figs. 10-13). It differs from both by having somewhat weaker constrictions; longer, denser, nearly radial primary ribs that bifurcate higher on the flanks; and fewer and stronger secondary ribs. Its general appearance is similar to that of the paratype of $C$. engleri Frebold (1957, p. 65, 76, pl. 40, figs. 1a, b) from western Alberta, but it has weaker constrictions, apparently higher points of rib furcation, and more distinct arching of ribs on its venter. It likewise resembles Leptosphinctes (Vermisphinctes) reparator Buckman (1923, pl. 366) at a comparable size but differs in having nearly radial primary ribs and in being more involute. In those features it resembles $L$. (Prorsisphinctes) omphalicus Buckman (1922, v. 4, pl. 326).

Holotype.-USNM 240765.

Occurrence.-Bowser Formation, about 150 feet below top at USGS Mesozoic locality 30261 west of Cook Inlet.

\section{REFERENCES CITED}

Arkell, W. J., 1950-58, Monograph of the English Bathonian ammonites: London, Palaeontographical Soc., 8 v., 33 pl., 83 figs.

Arkell, W. J., and others, 1957, Mesozoic Ammonoidea, in Moore, R. C., ed., Treatise on invertebrate paleontology, Part L, Mollusca 4, Cephalopoda, Ammononoidea: New York and Lawrence, Kans., Geol. Soc. America and Univ. Kansas Press, p. L80-L437.

Bourquin, J. D. R., 1967-1968, Les Reineckéidés, 169 p. (1968), 51 pls. (1967), 30 figs. (1967): Besançon Univ., Annales Sci. Ser. 3, Géologie, pt. 4, 3 v.

Buckman, S. S., 1909-30, Yorkshire type ammonites, v. 1 and 2 (1909-19); Type Ammonites, v. 3-7 (1920-30), ed. A. M. Davies (1930). London, Weldon and Wesley Ltd., 7 v. For details of publishing dates see Donovan, D. T., 1954, Synoptic supplement to T. Wright's "Monograph on the Lias ammonites of the British Islands," Palaeontographical Soc., v. 107, p. 9.

Callomon, J. H., 1959, The ammonite zones of the Middle Jurassic beds in East Greenland: Geol. Mag., v. 96, no. 6, p. 505-513, pls. 17, 18.

-1964, Notes on the Callovian and Oxfordian Stages in Colloque du jurassique à Luxembourg, 1962, [comptes rendus et mèmoríes]: [Luxembourg], Inst. Grand-Ducal, Sect. Sci. Nat., Phys., Math., p. 269-291.

Callomon, J. H., Donovan, D. T., and Trumpy, Rudolf, 1972, An annotated map of the Permian and Mesozoic formations of East Greenland: Medd. Grönland, v. 168, no. 3, p. 1-36, 9 figs., 3 tables.

Detterman, R. L., and Hartsock, J. K., 1966, Geology of the Iniskin Tuxedni region, Alaska: U.S. Geol. Survey Prof. Paper 512, 78 p., 6 pls., 7 figs.

Donovan, D. T., 1953, The Jurassic and Cretaceous stratigraphy and paleontology of Traill $\varnothing$, East Greenland: Medd. Grönland, v. 111, no. 4,150 p., 25 pls., 14 figs.

1957, The Jurassic and Cretaceous systems in East Greenland: Medd. Grönland, v. 155, no. 4, 214 p., 4 pls., 25 figs.

Frebold, Hans, 1957, The Jurassic Fernie group in the Canadian Rocky Mountains and foothills: Canada Geol. Survey Mem. 287, 197 p., 44 pls., 5 figs.
1961, The Jurassic faunas of the Canadian Arctic-Middle and Upper Jurassic ammonites: Canada Geol. Survey Bull. 74, 43 p., 21 pls., 3 figs.

1964, The Jurassic faunas of the Canadian Arctic-Cadoceratinae: Canada Geol. Survey Bull. 119, 27 p., 19 pls., 1 fig.

Frebold, Hans, and Tipper, H. W., 1973, Upper Bajocian-lower Bathonian ammonite fauna and stratigraphy of Smithers area, British Columbia: Canadian Jour. Earth Sci., v. 10, no. 7, p. 1109-1131, pls. 1-8, 3 figs., 2 tables.

Gabilly, Jean, Contini, Daniel, Mouterde, Rene, and Rioult, Michel, 1971, Les zones du Jurassique en France-bajocian: Soc. Géol. France Compte Rendu, no. 2, p. 85-88.

Grantz, Arthur, 1960a, Geologic map of Talkeetna Mountains (A-2) quadrangle, Alaska, and the contiguous area to north and northwest: U.S. Geol. Survey Misc. Geol. Inv. Map I-313.

$1960 \mathrm{~b}$, Geologic map of Talkeetna Mountains (A-1) quadrangle, and the south third of Talkeetna Mountains (B-1) quadrangle. Alaska: U.S. Geol. Survey Misc. Geol. Inv. Map I-314.

1965, Geologic map and cross sections of the Nelchina area, south-central Alaska: U.S. Geol. Survey open-file rept., 4 sheets, scale 1:63,360.

Hahn, Wolfgang, 1969, Die Perisphinctidae Steinmann (Ammonoidea) des Bathoniums (Brauner Jura) in sudwestdeutschen Jura: BadenWürttemberg Geol. Landesamt Jahreshift, v. 11, p. 29-86, pls. $1-9,11$ figs.

1971, Die Tulitidae S. Buckman, Sphaeroceratidae S. Buckman und Clydoniceratidae S. Buckman (Ammonoidea) des Bathonian (Brauner Jura) im sudwestdeutschen Jura: Baden-Württemberg, Geol. Landesamt Jahreshift, v. 13, p. 55-122, pls. 1-9, 13 figs.

Imlay, R.W., 1953, Callovian (Jurassic) ammonites from the United States and Alaska, Part 2. Alaska Peninsula and Cook Inlet regions: U.S. Geol. Survey Prof. Paper 249-B, p. 41-108, pls. 25-55, figs. 3-9.

1962a, Jurassic (Bathonian or early Callovian) ammonites from Alaska and Montana: U.S. Geol. Survey Prof. Paper 374-C, 32 p., 8 pls.

1962b, Late Bajocian ammonites from the Cook Inlet region, Alaska: U.S. Geol. Survey Prof. Paper 418-A, 15 p., 5 pls., 4 figs.

1964, Upper Jurassic mollusks from eastern Oregon and western Idaho: U.S. Geol. Survey Prof. Paper 483-D, p. D1-D21, pls. $1-4,3$ figs.

1975, Stratigraphic distribution and zonation of Jurassic (Callovian) ammonites in southern Alaska: U.S. Geol. Survey Prof. Paper $836,28 \mathrm{p} ., 6 \mathrm{pl}$.

1976, Middle Jurassic (Bajocian and Bathonian) ammonites from northern Alaska: U.S. Geol. Survey Prof. Paper 854, 22 p., 4 pls.

Imlay, R. W., and Detterman, R. L., 1973, Jurassic paleobiogeography of Alaska: U.S. Geol. Survey Prof. Paper 801, 34 p., 15 figs.

Kopik, Janusz, 1974, Genus Cadomites Munier-Chalmas, 1892 (Ammonitina) in the upper Bajocian and Bathonian of the Cracow-Wielun Jurassic range and the Gory Swietkrzyskie Mountains (southern Poland) in $\mathbf{Z}$ badan stratygraficznopaleontologicznych w Polsce, Tom VII: Poland, Inst. Geol., Biul. 276., p. 7-53, 11 pls. 2 figs.

Krimholz, G. Y., 1939, LMaterials on the geology of the Bureya coal basin, fascicle 4; Contribution to the stratigraphy of the Jurassic marine strata on the Bureya river, East Siberia]: USSR. [United Central Geol. and Prosp. Inst. Trans], v. 117, 60 p., 3 pls. (in Russian).

McLearn, F. H., 1928, New Jurassic ammonoidea from the Fernie formation Alberta: Canada Geol. Survey Bull. 49, Geol. Ser, no. 48, p. $19-22$, pls. $4-8$.

1929 , Contributions to the stratigraphy and paleontology of Skidegate Inlet, Queen Charlotte Islands, British Columbia: Canada Natl. Mus. Bull. 54, Geol. Ser. no. 49, p. 1-27, 16 pls. 
MacKevett, E. M., Jr., 1969, Three newly named Jurassic formations in the McCarthy C-5 quadrangle, Alaska, in Cohee, G. V., and others, Changes in stratigraphic nomenclature by the U.S. Geological Survey, 1967: U.S. Geol. Survey Bull. 1274-A, p. A35A49, figs. 3-8.

1970, Geologic map of the McCarthy C-5 quadrangle, Alaska: U.S. Geol. Survey Geol. Quad. Map GQ-S 899, Scale 1:63,360.

1971, Stratigraphy and general geology of the McCarthy C-5 quadrangle, Alaska: U.S. Geol. Survey Bull. 1323, 35 p.

Madsen, Victor, 1904, On Jurassic fossils from East Greenland: Medd. Grönland, v. 29, no. 6, p. 157-210, pls. 6-10.

Orbigny, Alcide d', 1842-51, Paléontologie française: Terrains Jurassiques, v. 1, Céphalopodes: Paris, Masson, 642 p., 234 pls. [For exact dates of publication see C. D. Sherborn, 1899, On the dates of Paleontologie Francaise of d'Orbigny: Geol. Mag., n. ser., v. 6, p. 223-225].

Parsons, C. F., 1974, The sauzei and 'so-called' sowerbyi Zones of the Lower Bajocian: Newsletters on Stratigraphy, v. 3, no. 3, p. 153180, 4 figs., 2 tables.

Pavia, Giulio, and Sturani, Carlo, 1968, Étude biostratigraphique du Bajocien des Chaînes Subalpines aux environs de Digne (BassesAlpes): Soc. géol. Italiana Boll., v. 87, no. 2, p. 305-316, 3 figs.

Quenstedt, F. A. von, 1886-1887, Die Ammoniten des Schwabischen Jura, v. 2, Der Braune Jura: Stuttgart, p. 441-672, pls. 55-78 (1886), p. 673-815, pls. 79-90 (1887).

Ravn, J. P. J., 1911, On Jurassic and Cretaceous fossils from NorthEast Greenland: Medd. Grönland, v. 45, p. 433-500, pls. 32-38.

Roman, Frédéric, and Petourand, C., 1927, Etude sur la faune du Bajocien supérieur du Mont d'Or lyonnais (Ciret), Céphalopodes: Lyon Univ. Lab. Géologie Travaux, pt. 11, Mém. 9, p. 5-55, pls. 1-7.
Spath, L. F., 1932, The invertebrate faunas of the Bathonian-Callovian deposits of Jameson Land (East Greenland): Medd. Grönland, v. 87, no. 7, 158 p., 26 pls., 14 figs.

Stehn, E., 1924, Beiträge zur Kenntnis des Bathonien und Callovien in Südamerika: Neues Jahrb., Beilage-Band 49 for 1923, p. 52-158, 8 pls.

Sturani, Carlo, 1964, Ammoniti mediogiurassiche del Veneto-faune del Baiociano (Zone a garantiana e a parkinsoni): Padova Univ. Inst. Geologia e Mineralogia Mem. v. 24, p. 3-43, 4 pls.

1966, Ammonites and stratigraphy of the Bathonian in the DigneBarreme area (southeastern France, Dept. Basses-Alpes): Soc. Paleont. Italiano Boll., v. 5, no. 1, 57 p., 24 pls. (1967).

Surlyk, Finn, Callomon, J. H., Bromley, R. G., and Birkelund, Tuve, 1973, Stratigraphy of the Jurassic-Lower Cretaceous sediments of Jameson Land and Scoresby Land, East Greenland: Grönlands Geol. Undersögelse Bull., no. 105, p. 5-76, 8 pls., 37 figs.

Torrens, H. S., 1965, Revised zonal scheme for the Bathonian stage of Europe: Carpatho-Balkan Geol. Assoc. Cong., 7th, Sofia 1965, Reports, pt. 2, v. 1, p. 47-55, 2 figs.

Voronets, N. S., 1962, Stratigraphy and Cephalopod molluses of the Jurassic and Lower Cretaceous deposits of the Lena-Anabar region: Nauchno-Issled. Inst. Geologii Arktiki Trudy, v. 110, 111 p., 61 pls., 32 figs.

Wendt, Jobst, 1963, Stratigraphisch-Paläontologische Untersuchungen im Dogger Westsiziliens: Soc. Paleont. Italiana Boll., v. 2, no. 1, 145 p., pls. 6-24, 1 fig.

Westermann, G. E. G.. and Rioult, M., 1975, The lectotype of the ammonite Cadomites Psilacanthus (Wermbter): Palaeontology, v. 18 , pt. 4 , p. 871-877, pl. 105. 


\section{INDEX}

[Italic page numbers indicate descriptions and major references]

Page

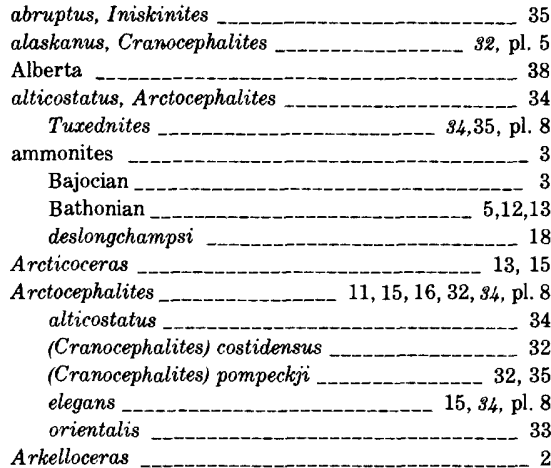

B

Bajocian Age __ 2, 3, 13, 14, 15, 16, 30 ammonites _-

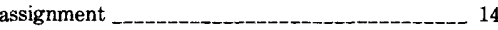
beds of England _. 37 bakeri, Phylloceras _. $16, \mathrm{pl} .1$ Bathonian Age $1,2,3,4,13,14,15,16,21,22,23,24,25$ $26,27,28,29,30$

ammonites $1,2,12,13$ beds Bear Creek _Belemnites -

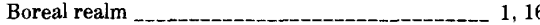
Boulder Creek Bowser Formation _- 1, 2, 5, 11, 12, 14, 15, 16, 17, 18, 30, $31,32,33,34,35,36,37,38$

British Columbia $-15,37$

\section{c}

cadiformus, Talkeetnites

$36, \mathrm{pl} .9$

Cadoceras

calyx

$15,16,36$ variable

Cadoceratinae _._._. 32

Cadomites ____ 2, 13, 16, 18, 20, 30, pl.4 daubenyi deslongchampsi _._._._._. 13, 18, 20, 29, 30, pl. 4 exstinctus rectelobatus _. $13,16,30, \mathrm{pl} .4$

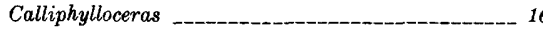
freibocki Phylloceras, freibocki Calliphylloceratinae _Callovian Age _._.___ $2,13,15$ calyx, Cadoceras

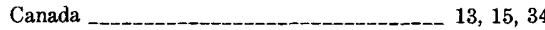
Cardioceratidae 2,32 Chinitna Bay _._.____ 2, 16, 35

Chinitna Formation ___ 2, 14, 15, 16, 17, 18, 30, 31 chinitnaensis, Chinitnites _....... 35 chinitnana, Oppelia (Oxycerites) _....... 17, pl. 3 Chinitnites $2,11,16,30,34$

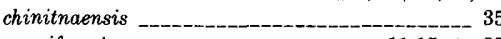
parviformis _... $11,15,30,35$
Page

Chisik Island

chisikensis, Kepplerites _-_.

Chondroceras _-

Cobbanites _- $2,11,14,16,87$ engleri striatus _._-___. talkeetnanus _________________-_ 37,38, pl. 12 tuxedniensis $14, s 7$, pl. 12 Cook Inlet - 1, 2, 3, 7, 11, 13, 15, 16, 30, 32, 34, 35, 36, 38 Coquinoid costidensus, Arctocephalites (Cranocephalites) _____ 32 Cranocephalites _ 11, 13, 14, 15, 16, 32, 33, 34, 35, 37 , pl. 7

Cranocephalites _- 2,11,13, 14, 16, 31, 32, 33, 34, 35, 36, pls. 3,5

alaskanus $32, \mathrm{pl}, 5$ Arctocephalites costidensus _._._._. 32 Arctocephalites pompeckji _-_._-_._-_._. 32,35 costidensus _ $11,13,14,15,16,32,33,34,35,37, \mathrm{pl}$. 7 globosus _._____ $39,35, \mathrm{pl} .6$ ignekensis _____ 11, 14, 15, 32, 34, pl. 5

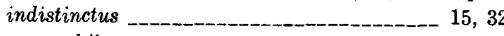
pompeckji_____________ $13,15,16,32$ vulgaris __________________ 11, 15, 33, 34, pl. 3

D

daubenyi, Cadomites densicostatus _-_ 37 deslongchampsi, ammonites _._. 18 cadomites $13,18,20,29,30, \mathrm{pl} .4$

\section{$\mathbf{E}$}

Early Jurassic

East Boulder Creek

East Greenland _._._._._._._._._._. 13, 15, 16, 33, 34

elegans, Arctocephalites _...___ 15, 34, pl. 8

engleri, Cobbanites ____________ 38

eudisianum, Lytoceras

exstinctus, Cadomites

$\mathbf{F}$

freibocki, Calliphylloceras

Phylloceras (Calliphylloceras) 16, pl. 1

\section{G}

Gaikema Creek

gitinsi, Kepplerites grossicostatum, Phylloceras (Macrophylloceras) _ 16, pl. 1

\section{$\mathbf{H}$}

hebetus, Xenocephalites hickersonensis, Parareineckeia $30, \mathrm{pl} .2$ $36,37, \mathrm{pl} .10$

ignekensis, Cranocephalites __-_-_ 11, 14, 15, 32, 34, pl. 5 indistinctus, Cranocephalites Iniskin Bay

Iniskin Peninsula , $32,34, \mathrm{pl} .5$ $1,2,5,7,11,15,35$ $2,15,17,33,35,36,37$
Page

Iniskinites abruptus intermedius $11,16,35, \mathrm{pl} 8$ magniformus _________ $35, \mathrm{pl} .8$ Inoceramus _. 2 intermedium, Kheraiceras _-___- 35 intermedius, Iniskinites _.________._. 11, 16, 35, pl. 8

\section{J}

Jurassic Age 13

\section{K}

kellumi, Oppelia (Liroxyites) 18, pl. 3 Kepplerites Kepplerites _-_
chisikensis gitinsi

meevoyi _- 31 multus tychonis

Kheraiceras intermedium

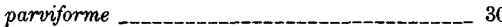
Kosmoceratidae $\mathbf{L}$

Lake Hickerson $11,15,35,36$ Leptosphinctes (Prorsisphinctes) omphalicus _-_._-_-_ 38

(Vermisphinctes) reparator _______ 37, 38

(Vermisphinctes) subdivisus _________________-_ 37

(Vermisphinctes) vermiformis _._._. 37

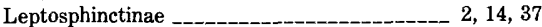

Limestone Hills _._.

Liroxyites _____ Oppelia Oppelia kellumi $18, \mathrm{pl} .3$

Little Nelchina River Valley Oshetna River Lubbe Creek Formation

Lytoceras $16,17, \mathrm{pl} .2$

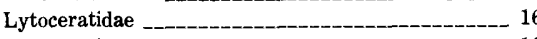

Lytoceratinae _._. 16

$\mathbf{M}$

Macrocephalitidae 30

Macrophylloceras 16 Phylloceras, grossicostatum _____ 16, pl. 1 magniformus, Iniskinites ______ $35, \mathrm{pl} .8$ McCarthy C-5 quadrangle

quation

mcevoyi, Kepplerites -

Mesozoic locality __- $16,17,30,31,32,33,35,36,37,38$, pls. $1,2,3,4,5,6,7,8,9,10,11,12$

Middle Jurassic

multus, Kepplerites _-

Nelchina $1,2,4$ nelchinensis, Parareineckeia Nizina Mountain Formation Normannites 36,37
--13 


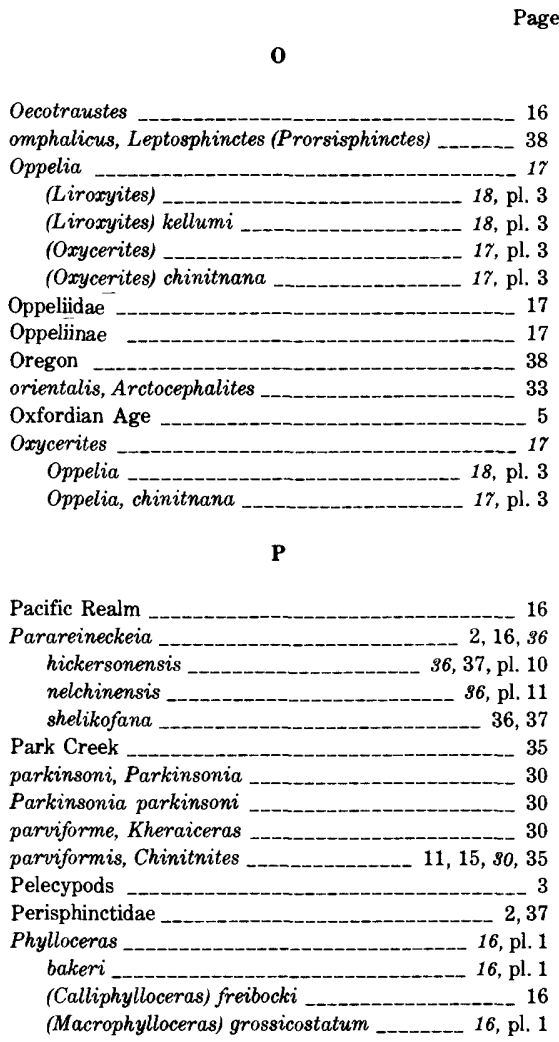

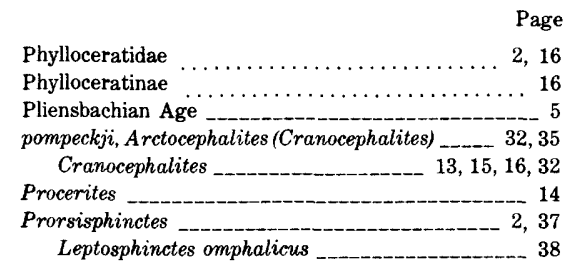

$\mathbf{R}$

rectelobatus, Cadomites _-_________ 13, 16,30, pl. 4

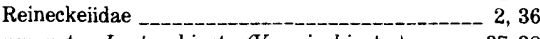
reparator, Leptosphinctes (Vermisphinctes) _._._. 37, 38 Root Glacier Formation

\section{s}

Shelikof Formation shelikofana, Parareineckeia Siemeradzkia _____ 13,16

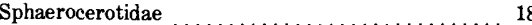

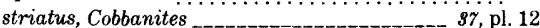
subdivisus, Leptosphinctes (Vermisphinctes) _______ 37

\section{$\mathbf{T}$}

Talkeetna Formation Mountains $1,2,4,5,11,12,13,15,16,17,29,30,32$ $33,35,36,37$

talkeetnanus, Cobbanites $\quad 37, \mathrm{pl} .12$ Talkeetnites _._. $2,16,35,36$ cadiformus $36, \mathrm{pl} .9$

Teloceras ___________ 13

Tithonian Age

Tonnie Creek _. 11

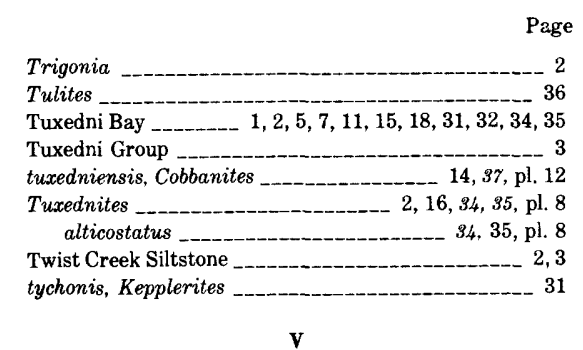

variable, Cadoceras _._._...- 15 vermiformis, Leptosphinctes (Vermisphinctes) _..._. 37

Vermisphinctes 2,14 Leptosphinctes reparator _._._- 37, 38 Leptosphinctes subdivisus ________________ 37

Leptosphinctes vermiformis $11,15,33,34$, pl. 3 vulgaris, Cranocephalites

\section{$\mathbf{w}$}

Wrangell Mountains__ $1,2,4,5,13,29,30,32,35,36,37$

Xenocephalites hebetus $11,15,16,30,35, \mathrm{pl} .2$ so, pl. 2

zigzag, zigzagiceras

$\mathbf{Z}$

30

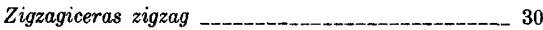
Zigzagiceratinae 


\section{PLATES}

Contact photographs of the plates in this report are available, at cost, from U.S. Geological Survey Library, Federal Center,

Denver, Colorado 80225 


\section{PLATE 1}

[Figures natural size unless otherwise indicated]

Figures 1, 2, 4, 5. Kepplerites sp. A (p. 31).

1, 2, 4. Figured specimens USNM 240721 from Mesozoic loc. 21319. Figures 1 and $2(\times 2)$ represent inner whorl of specimen shown on figure 4 .

5. Figured specimen, USNM 180716 from USGS Mesozoic loc. 21319. Note absence of lateral tubercles.

3. Kepplerites sp. C (p. 31).

Lateral view $(\times 2)$. Figured specimen, USNM 240723 from USGS Mesozoic loc. 30263.

6, 10. Phylloceras ef. $P$. bakeri Imlay (p. 16).

Figured specimen, USNM 240705 from USGS Mesozoic loc. 21311.

7-9, 11. Calliphylloceras freibrocki Imlay (p. 16).

7, 11. Hypotype, USNM 240708 from USGS Mesozoic loc. 30578.

8, 9. Hypotype, USNM 240707 from USGS Mesozoic loc. 21311.

12, 13. Phylloceras (Macrophylloceras) grossicostatum Imlay (p. 16).

Hypotype, USNM 240706 from USGS Mesozoic loc. 30574. 


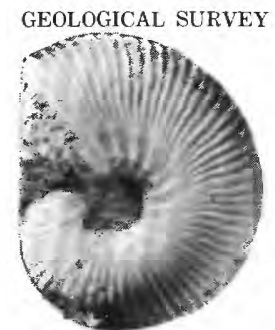

1

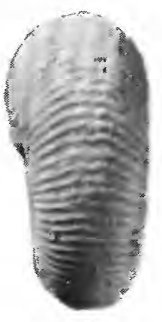

2

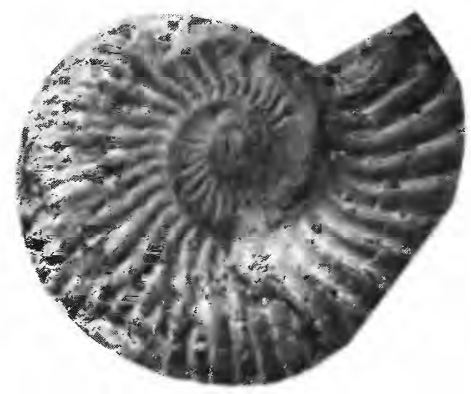

3

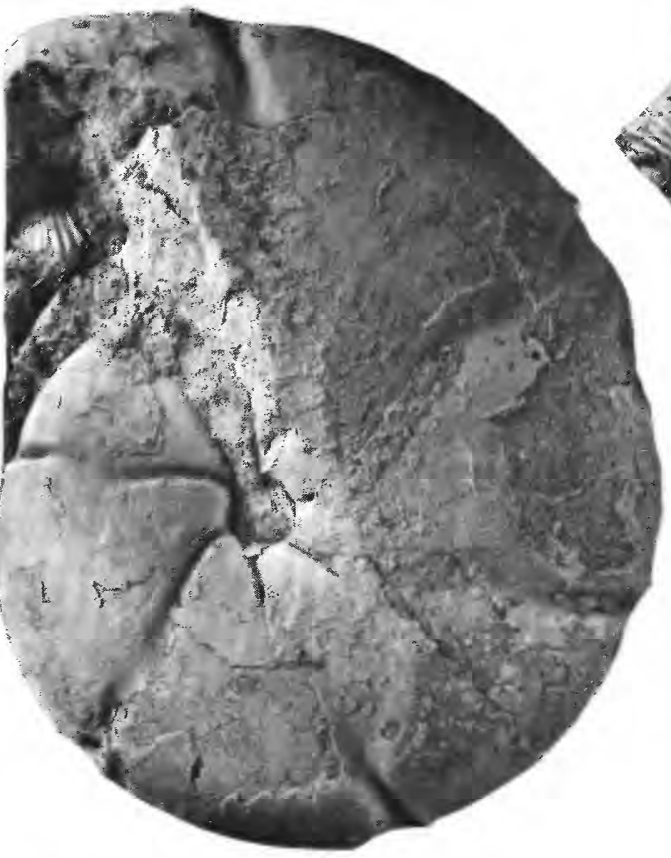

7

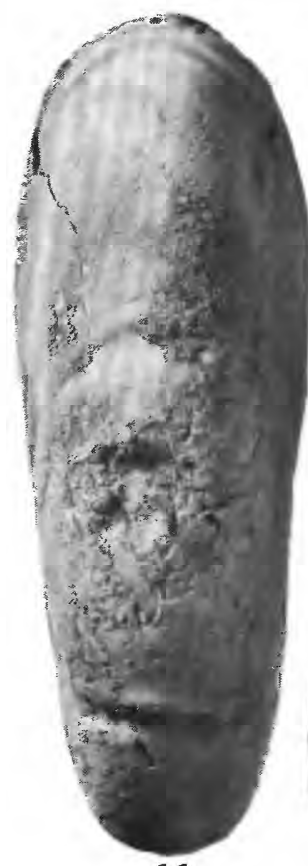

11

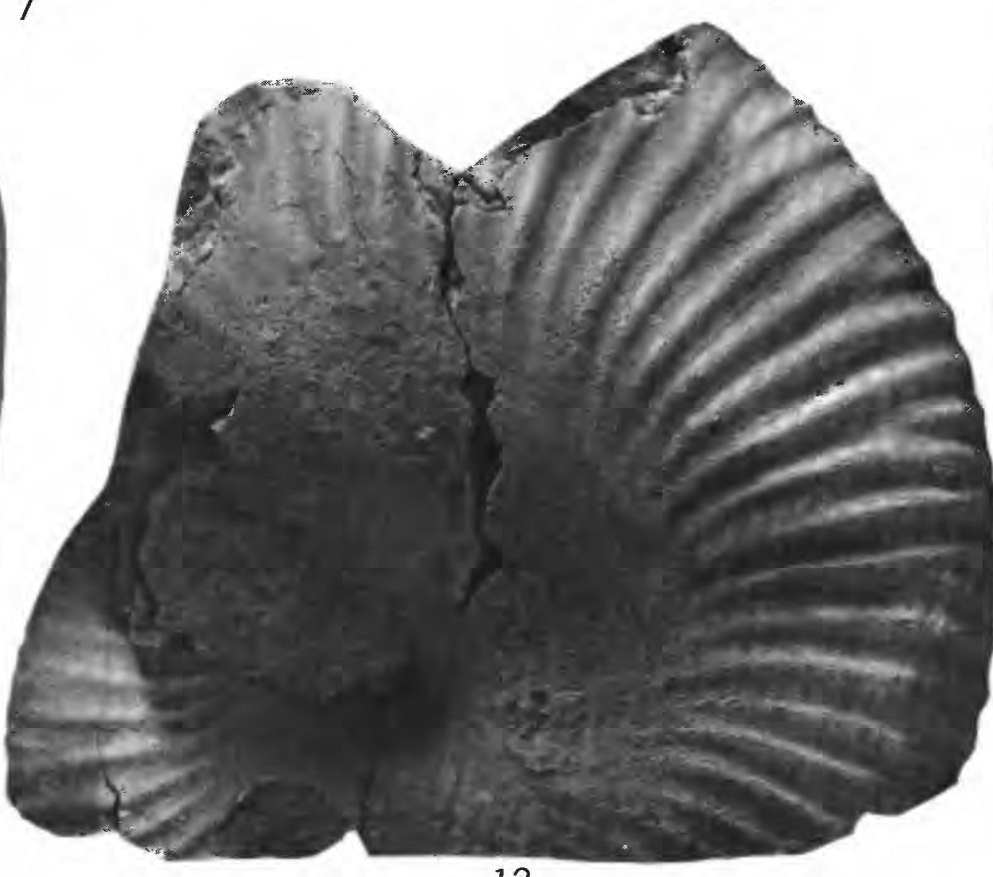

12

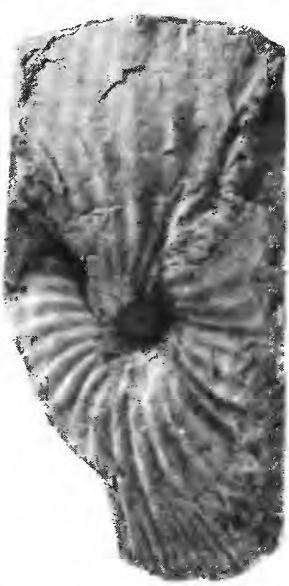

5
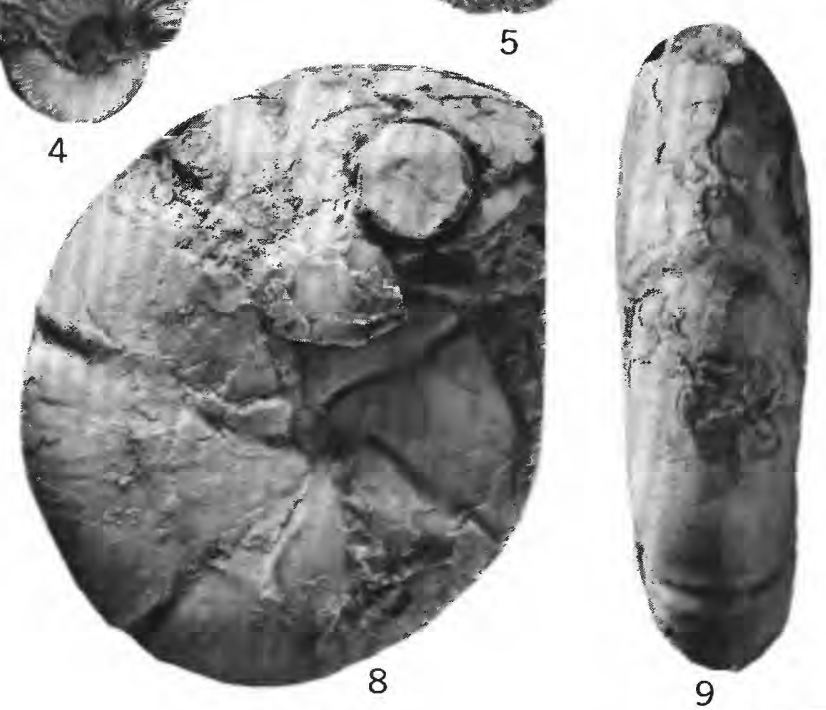

6
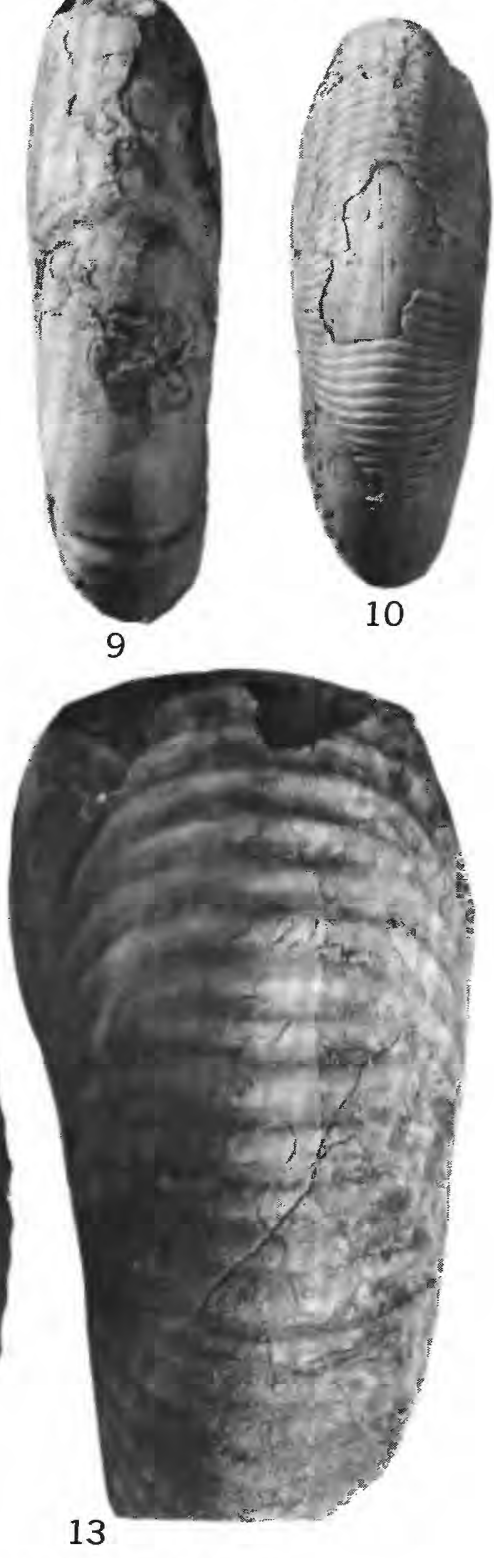

KEPPLERITES, PHYLLOCERAS, CALLIPHYLLOCERAS, AND MACROPHYLLOCERAS 


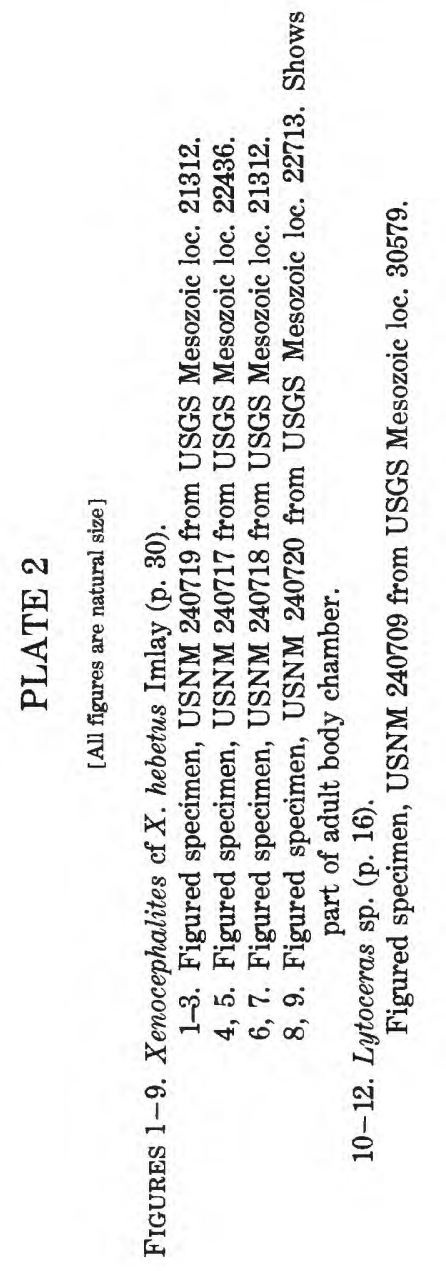



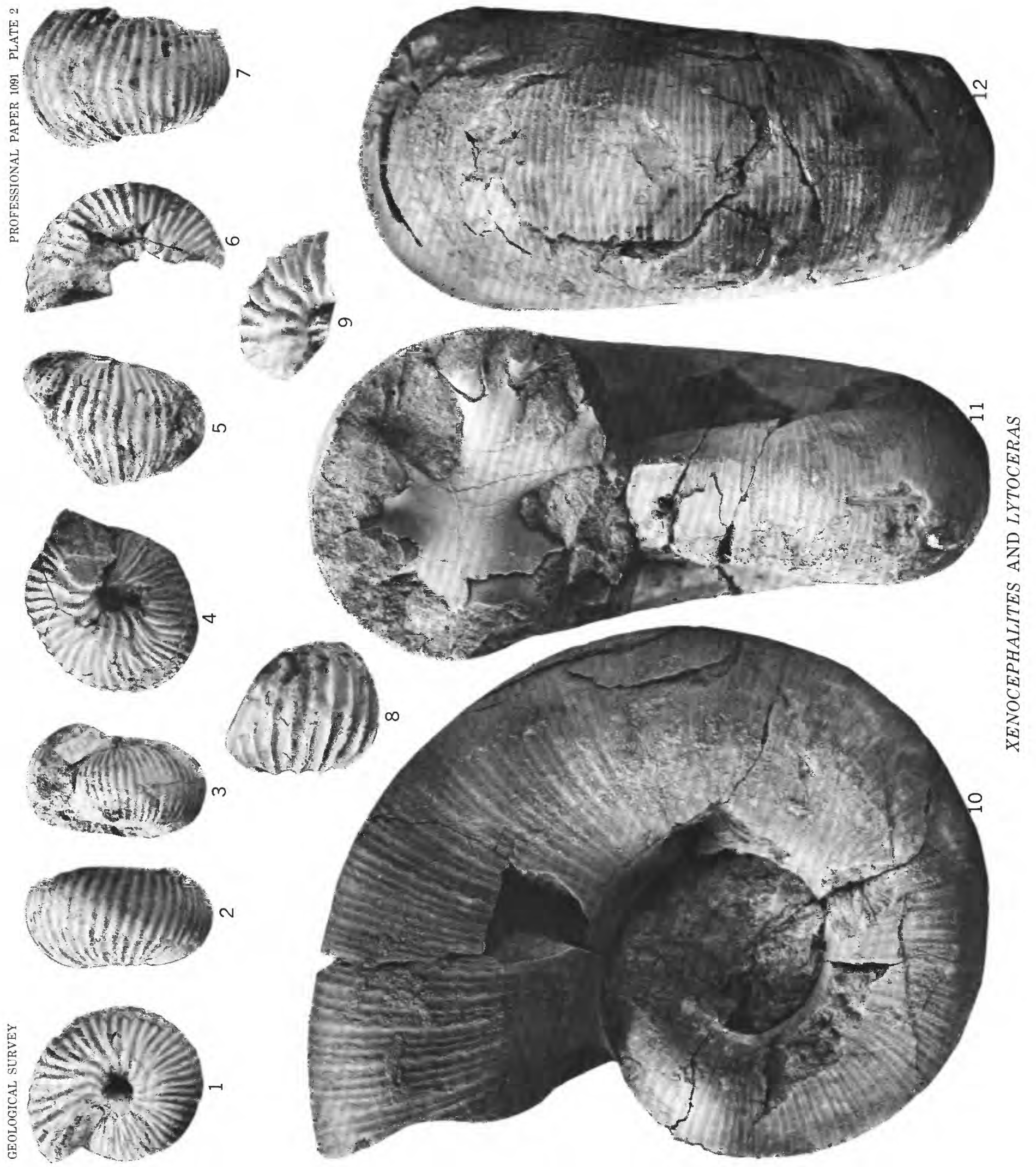


\section{PLATE 3}

[All figures are natural size]

Figures 1-5. Oppelia (Oxycerites) aff. O. (O.) chinitnana Imlay (p. 17).

Figured specimen, USNM 240710 from USGS Mesozoic loc. 22538.

6. Oppelia (Liroxyites) ef $O$. (L.) kellumi Imlay (p. 18).

Figured specimen, USNM 240711 from USGS Mesozoic loc. 30257.

7, 8, 10, 11. Cranocephalites cf. C. vulgaris Spath (p. 33).

Figured specimen, USNM 240734 from USGS Mesozoic loc. 30275. Shows aperatural, ventral, cross-sectional, and lateral views of adult body chamber.

9. Kepplerites sp. B (p. 31).

Figured specimen, USNM 240722 from USGS Mesozoic loc. 30258. Shows adult body chamber. 
GEOLOGICAL SURVEY

PROFESSIONAL PAPER 1091 PLATE 3

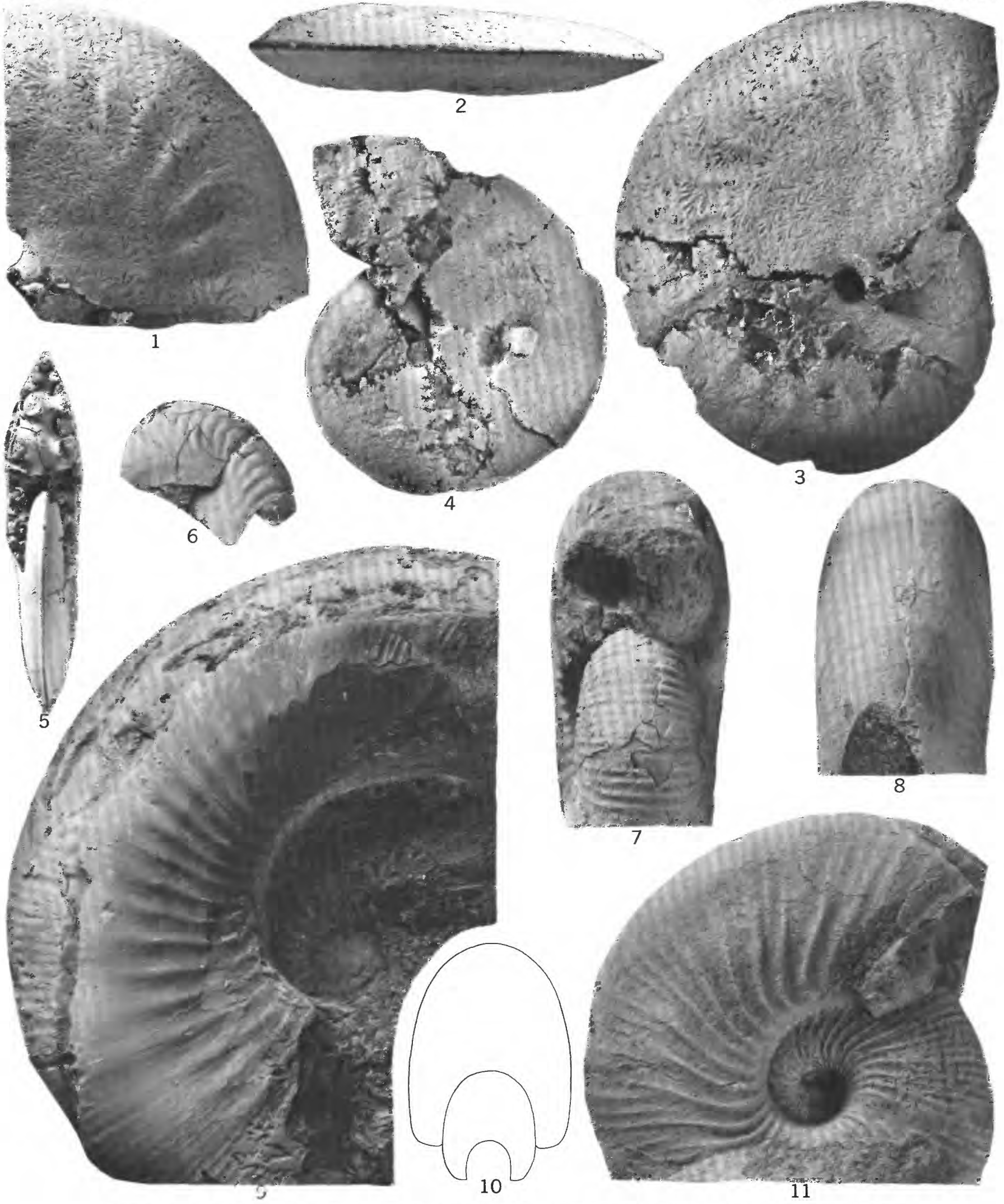

OPPELIA (OXYCERITES), O. (LIROXYITES), CRANOCEPHALITES, AND KEPPLERITES 


\section{PLATE 4}

[All figures are natural size]

Figures 1, 2, 4-12. Cadomites cf. C. deslongchampsi (d'Orbigny) (p. 18).

$1,2,4,5$. Nonseptate specimens, USNM 240714 from USGS Mesozoic loc. 30576. Shows lateral views (figs. 1 and 2), ventral view (fig. 4), and rubber latex imprint of dorsal surface of adoral part of adult body chamber (fig. 5).

6, 7. Septate specimen, USNM 240713 from USGS Mesozoic loc. 30577. This small specimen was part of an umbilical plug that was detached from the specimen shown in figures 9-12.

8. Rubber imprint of external mold of specimen, USNM 240715 from USGS Mesozoic loc. 28682.

9-12. Ventral and lateral views of specimen, USNM 240712 from USGS Mesozoic loc. 30277. Note that the adoral end has been crushed vertically.

3. Cadomites cf. C. rectelobatus (v. Hauer) (p. 30).

Rubber imprint of laterally crushed external mold of specimen, USNM 240716 from USGS Mesozoic loc. 28682. 
GEOLOGICAL SURVEY
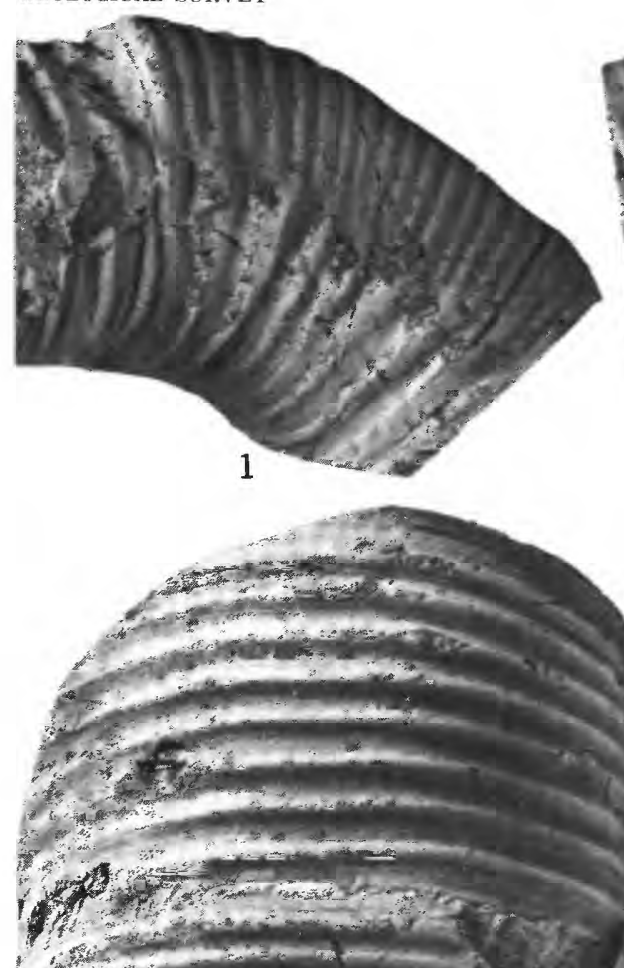
드.-

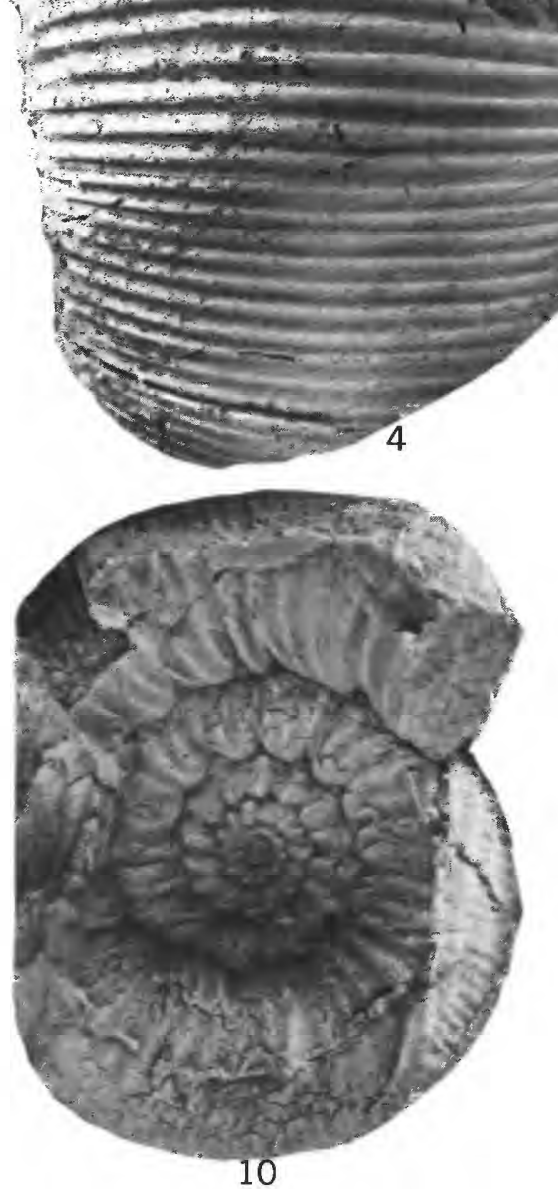

PROFESSIONAL PAPER 1091 PLATE 4 


\section{PLATE 5}

[All figures are natural size]

Figures 1-5. Cranocephalites alaskanus Imlay n. sp. (p. 32).

14. Lateral, apertural, and ventral views of holotype, USNM 240729 from USGS Mesozoic loc. 22698.

5. Immature paratype, USNM. 130753 from USGS Mesozoic loc. 22698.

6-8. Cranocephalites sp. A (p. 33).

Lateral and ventral views of specimen, USNM 240735 from USGS Mesozoic loc. 22436.

9-11. Cranocephalites cf. C. ignekensis Imlay (p. 32).

9. Rubber imprint of external mold of specimen, USNM 240730 from USGS Mesozoic loc. 30275 .

10, 11. Lateral views of specimen, USNM 130751 from USGS Mesozoic loc. 21284 

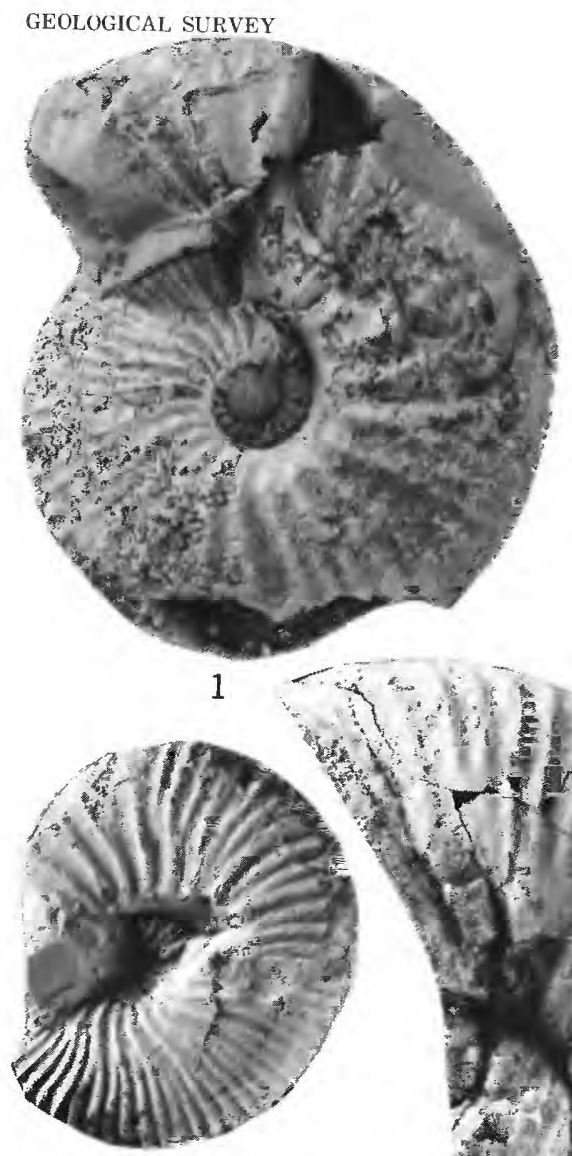

5

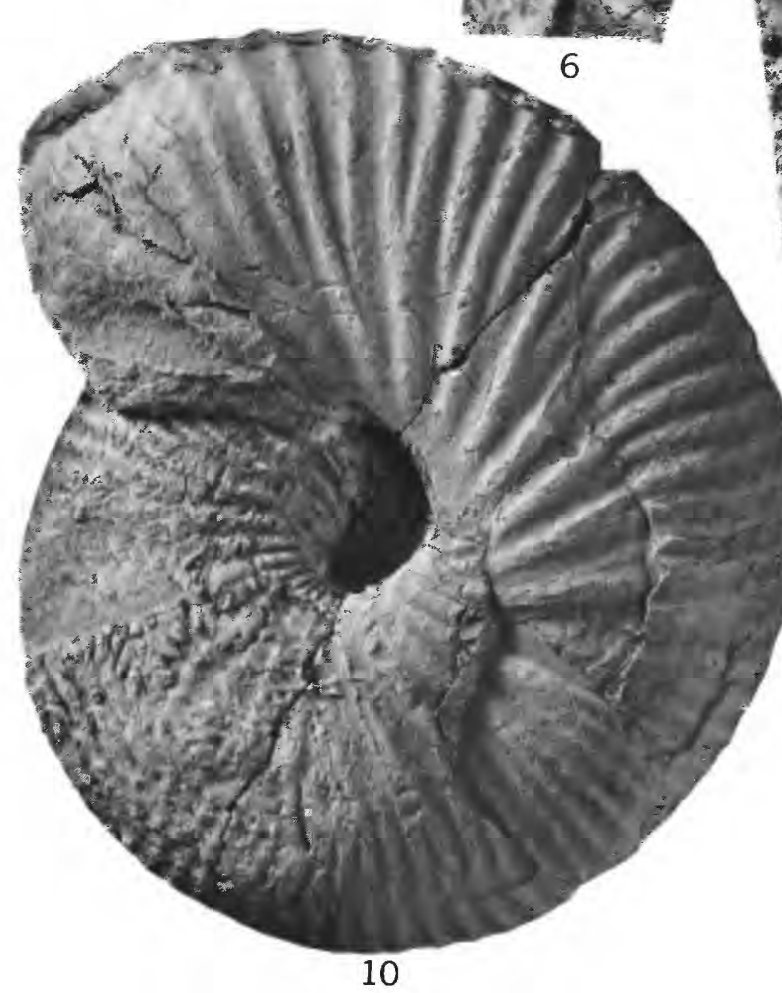

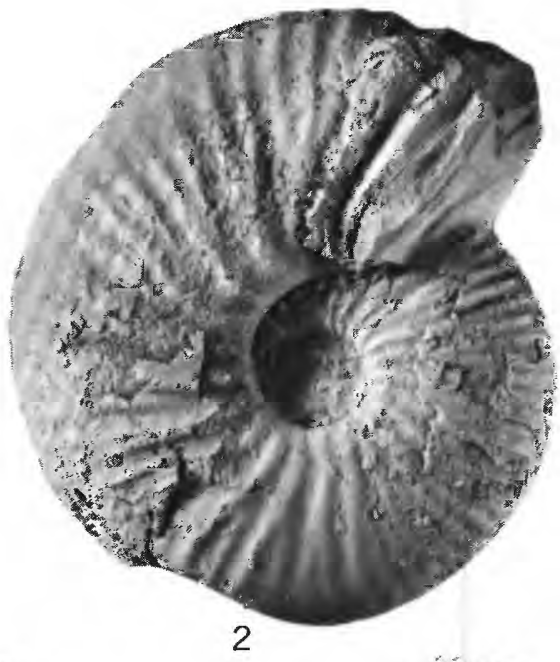

-

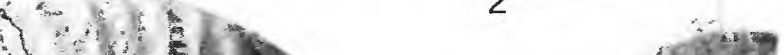

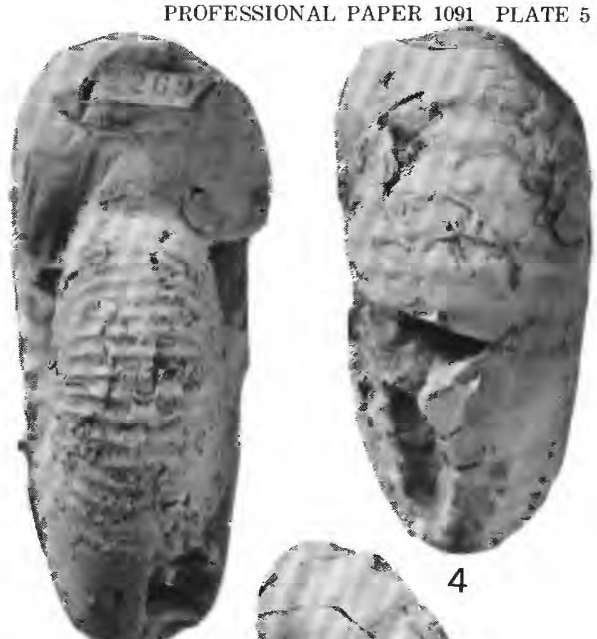

3

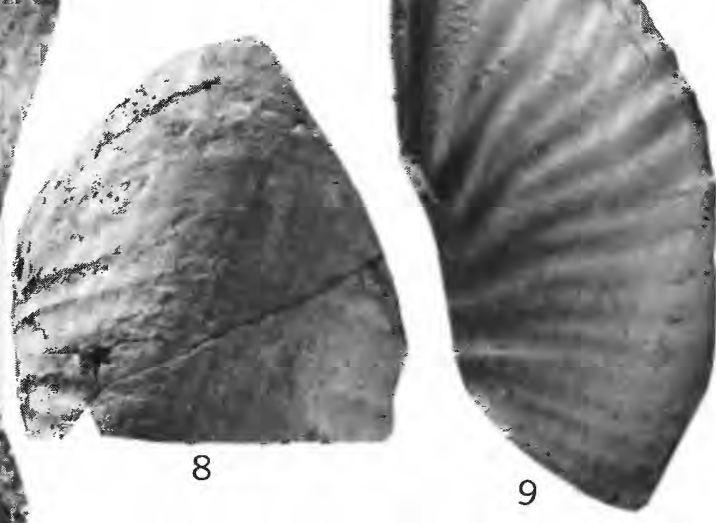

hof vip

c.3 12 r

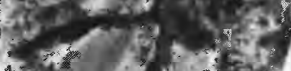

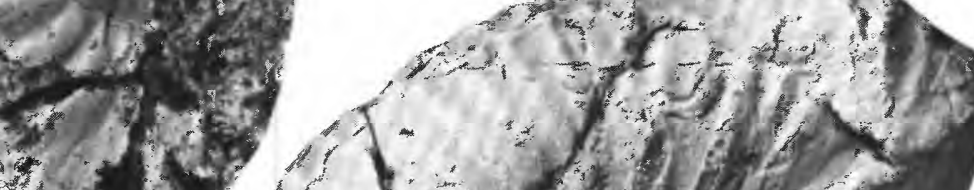

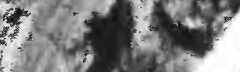
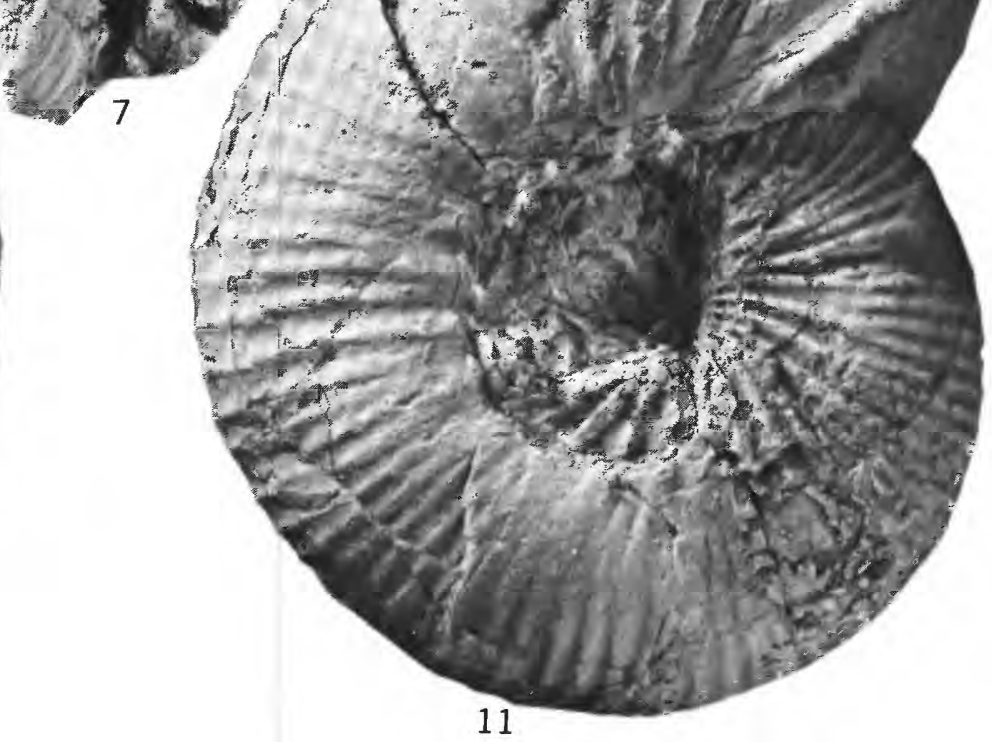

CRANOCEPHALITES 


\section{PLATE 6}

[All figures except suture line are natural size]

Figures 1-3, 5, 6, 8-13. Cranocephalites globosus Imlay n. sp. (p. 33).

1-3. Cross-sectional, ventral and lateral views of paratype, USNM 240732 from USGS Mesozoic loc. 20751.

5, 6. Paratype, USNM 240733 from USGS Mesozoic loc. 24117

8-13. Holotype, USNM 240731 from USGS Mesozoic loc. 24116. Figure 9 shows suture line $(\times 2)$ drawn at diameter of $53 \mathrm{~mm}$, whorl height of $15 \mathrm{~mm}$, and whorl thickness of $43 \mathrm{~mm}$. On Figures 10 and 13 note smoothness of venter near the apertural constriction. On Figure 11 note persistence of ribs on the flanks almost to the apertural constriction.

4, 7. Cranocephalites sp. B (p. 34).

Lateral and apertural views of specimen, USNM 240736 from USGS Mesozoic loc. 30257. 

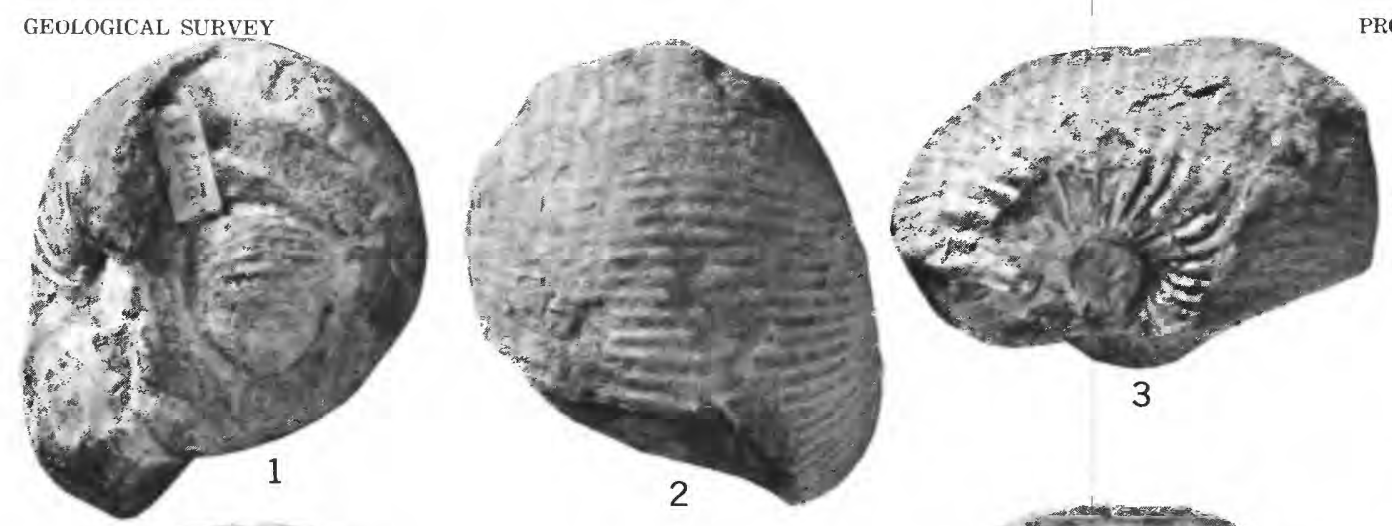

PROFESSIONAL PAPER 1091 PLATE 6
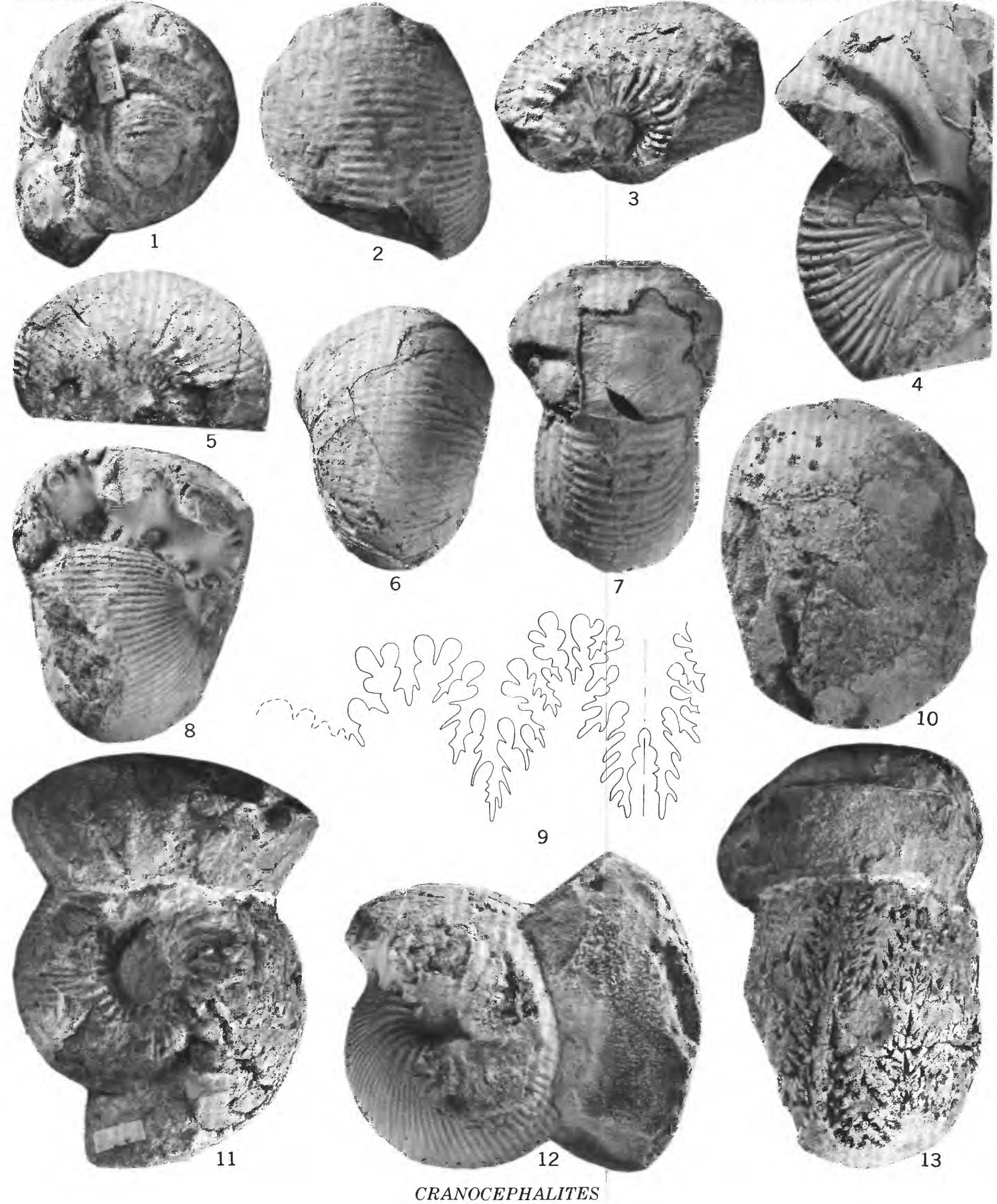


\section{PLATE 7}

[All figures natural size except suture lines]

Figures 1-12. Cranocephalites costidensus (Imlay) (p. 32).

$1-3,6$. Hypotype, USNM 240724 from USGS Mesozoic loc. 30273 has a compressed form and moderately strong ribbing. Figure 6 shows suture lines $(\times 2)$ drawn at adapical end of body chamber.

4, 12. Hypotype, USNM 240727 from USGS Mesozoic loc. 30277, has a compressed form and fairly fine ribbing.

5, 8. Hypotype, USNM 240725 from USGS Mesozoic loc. 30289, has a fairly stout form and moderately strong ribbing.

7. Suture line $(\times 2)$ on hypotype, USNM 240728 from USGS Mesozoic loc. 30277.

9-11. Hypotype, USNM 240726 from USGS Mesozoic loc. 30277, has a very stout form and fairly fine ribbing. 

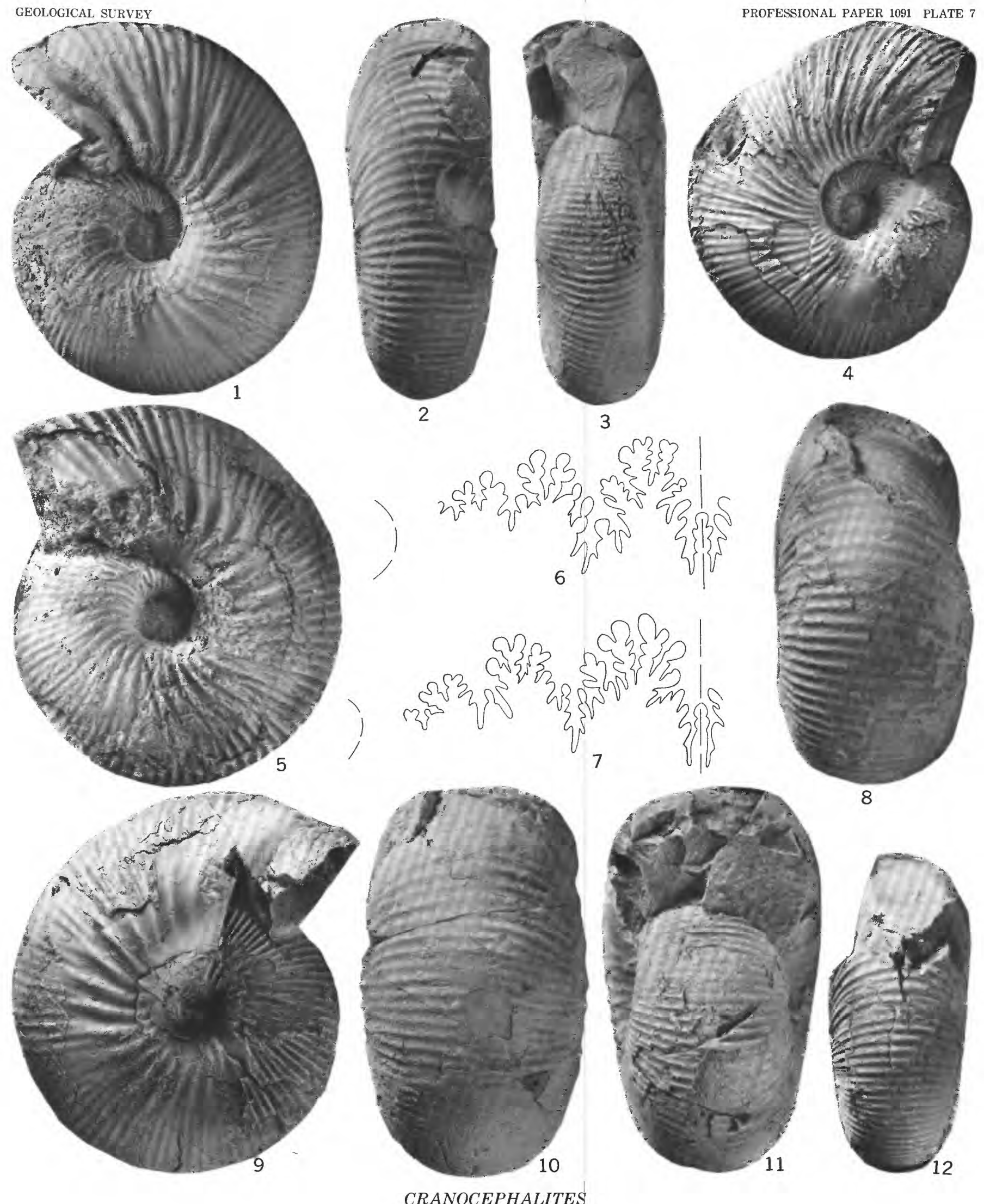

CRANOCEPHALITES 


\section{PLATE 8}

[All figures are natural size]

FIGURES 1-9. Tuxednites alticostatus (Imlay) (p. 34).

1, 2. Holotype, USNM 130757 from USGS Mesozoic loc. 20752.

3, 4. Hypotype, USNM 240739 from USGS Mesozoic loc. 30290.

5, 6. Hypotype, USNM 240738 from USGS Mesozoic loc. 30288.

7-9. Hypotype, USNM 240737 from USGS Mesozoic loc. 11038.

10-15. Tuxednites? sp. ind. (p. 35).

10,11 . Ventral and lateral view of internal mold of specimen, USNM 240742 from USGS Mesozoic loc. 30265.

12, 13. Rubber cast of external mold of same specimen shown in figures 10 and 11.

14, 15. Nonseptate specimen, USNM 240741 from USGS Mesozoic loc. 20744.

16, 17. Tuxednites cf. T. alticostatus (Imlay) (p. 35).

Specimen, USNM 240740 from USGS Mesozoic loc. 22698. Whorl section is slightly crushed.

18-21. Arctocephalites cf. A. elegans Spath (p. 34).

Specimen, USNM 108743 from USGS Mesozoic loc. 22699. Partial, nearly smooth body chamber is shown in figures 18 and 21 . On figure 21 the adoral end of body chamber is pointed upward.

22, 26-28. Iniskinites cf. I. intermedius (Imlay) (p. 35).

$22,27,28$. Ventral and lateral views of specimen, USNM 240744 from USGS Mesozoic loc. 30262.

26. Specimen, USNM 240743 from USGS Mesozoic loc. 22700.

23-25. Iniskinites ef. I. magniformis (Imlay) (p. 35).

23,25 . Crushed immature septate specimen, USNM 240745a from USGS Mesozoic loc. 22536.

24. Ventral view of uncrushed specimen, USNM $240745 \mathrm{~b}$ from USGS Mesozoic loc. 22536. 


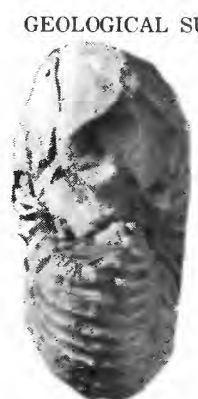

1

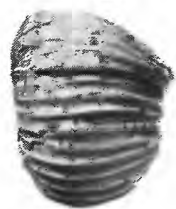

10

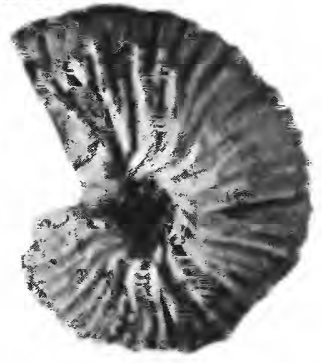

2

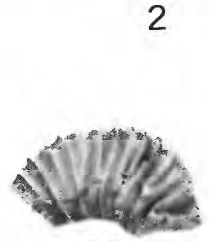

11

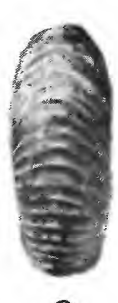

3

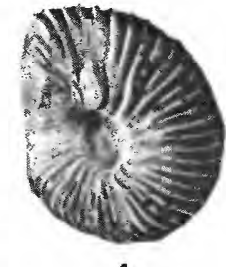

4

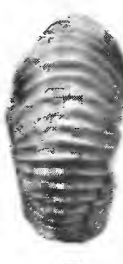

5

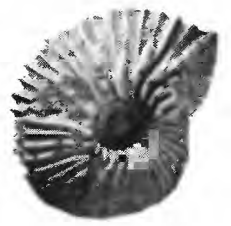

6
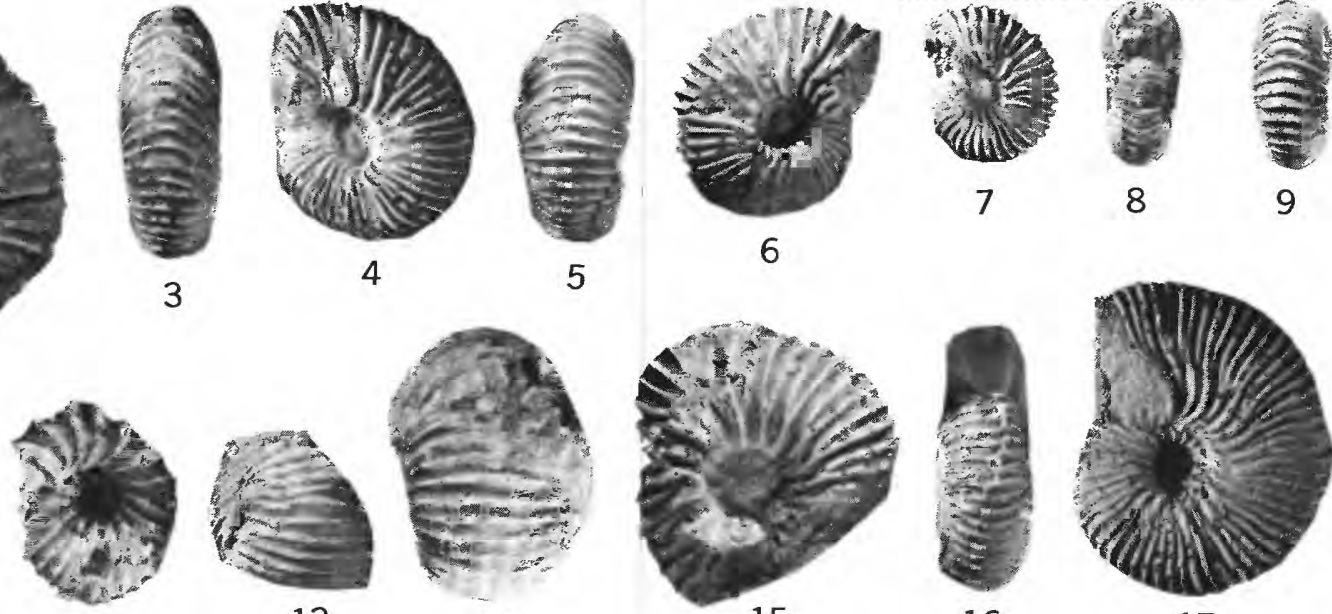

12
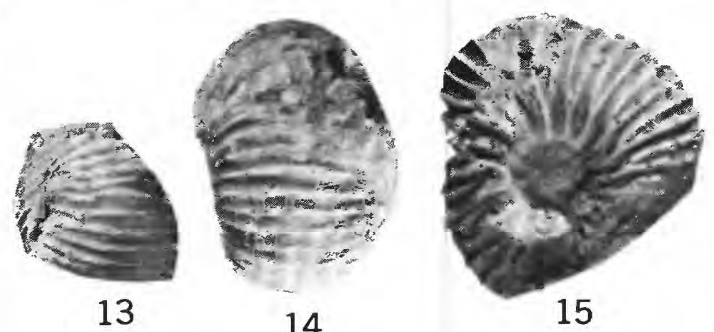

15
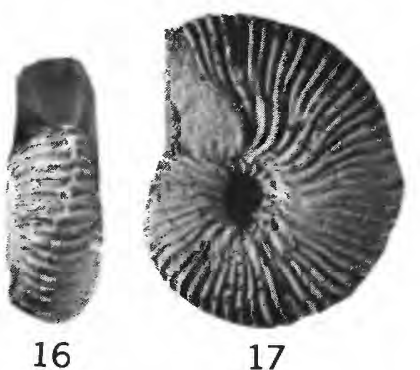

17
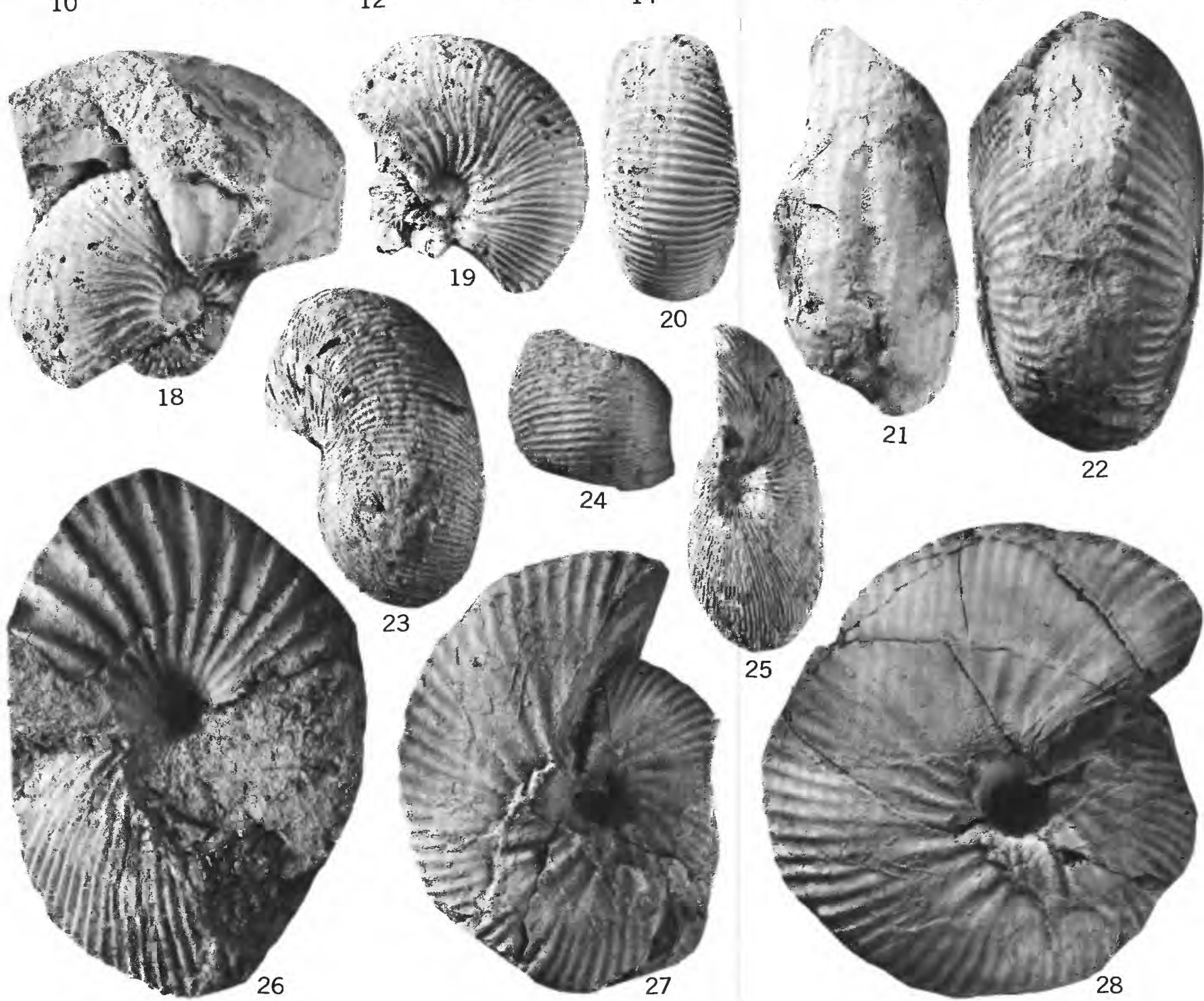

18

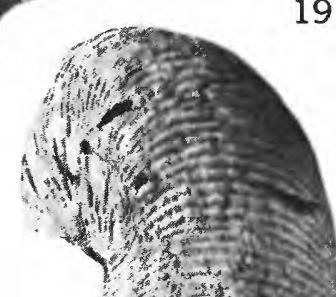

Fin

X.
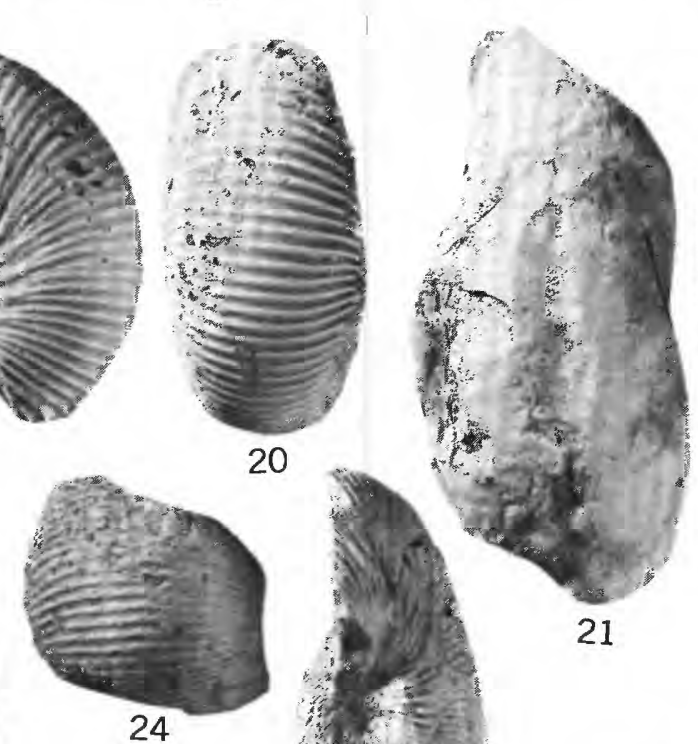

We
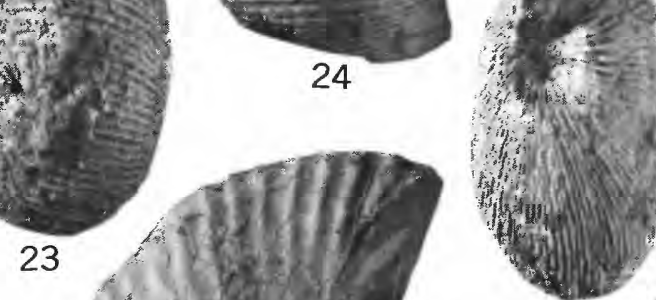

22

TUXEDNITES, TUXEDNITES?, ARCTOCEPHALITES, AND INISKINITES 


\section{PLATE 9}

[All figures are natural size]

Figures 1-10. Talkeetnites cadiformis Imlay, n. sp. (p. 36).

1-4, 6, 8-10. Holotype, USNM 240746 from USGS Mesozoic loc. 30277. Shows ventral, cross-sectional, and apertural views of incomplete body whorl. On Figure 1 the adoral part of the body chamber is pointed downward. Figure 4 is a line drawing cross-sectional view. Figures 9 and 10 represent the adoral half of the holotype split along the crack shown in figure 6 . Figures 2,3 , and 10 show the ribbing on a small inner whorl.

5, 7. Paratype, USNM 240747 from USGS Mesozoic loc. 30277. Lateral and ventral views of intermediate-sized septate whorl. 

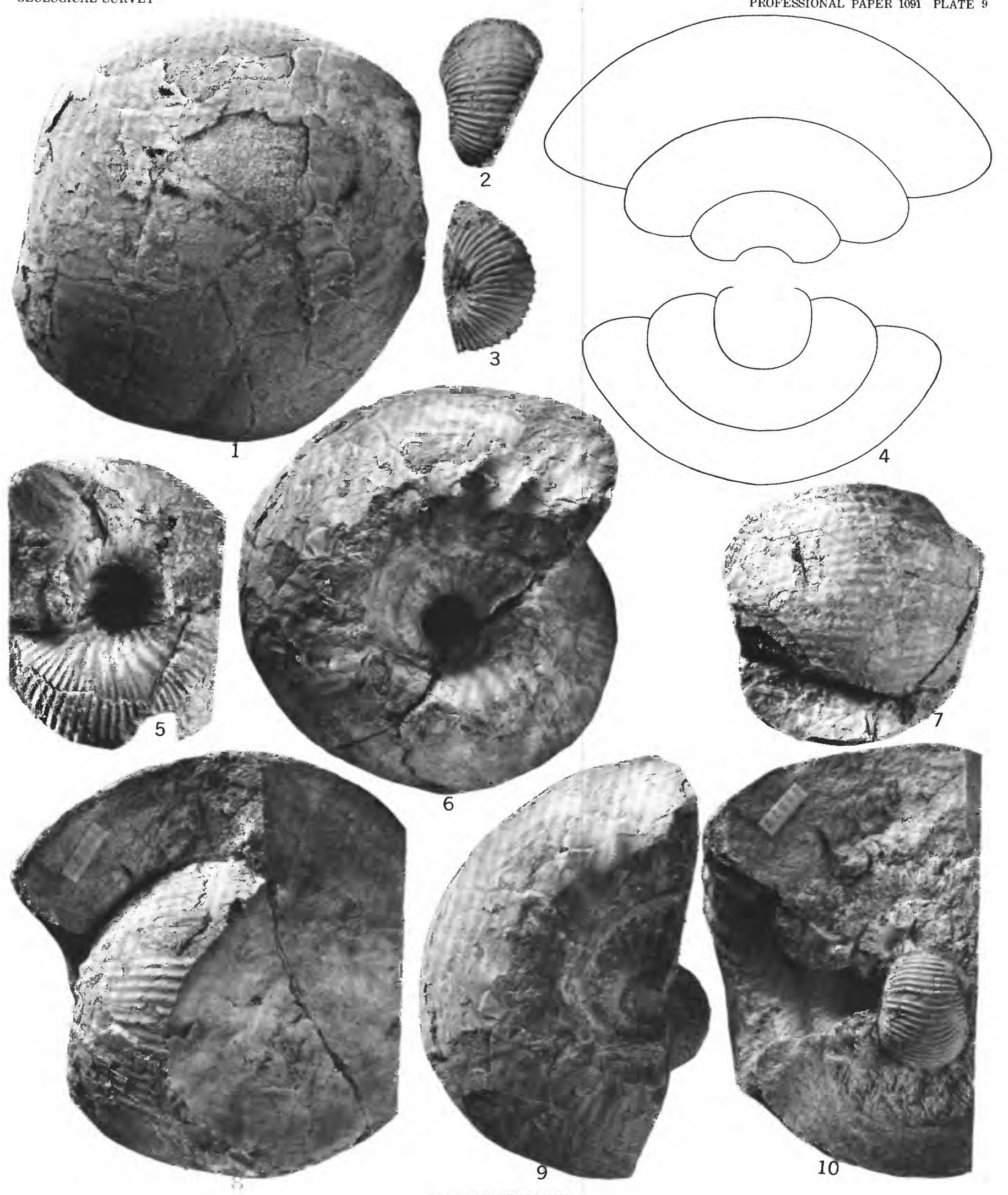


\section{PLATE 10}

[Figures natural size unless otherwise indicated]

Figures 1-10. Parareineckeia hickersonensis Imlay (p. 36).

1, 4, 6, 7, 9. Hypotype, USNM 240751 from USGS Mesozoic loc. 30576. Figures 6 and $7(\times 2)$ depict three inner whorls whose place of attachment is shown on Figure 9. Figures 1, 4, and 9 depict the outermost whorl of a microconch as shown by presence of a lateral lappet.

2. Rubber imprint of external mold of laterally crushed hypotype, USNM 240750 from USGS Mesozoic loc. 28682.

3,8 . Ventral and lateral views of hypotype, USNM 240752 from USGS Mesozoic loc. 30272. Note prominent spines in figure 3.

5. Rubber imprint of laterally crushed external mold of hypotype, USNM 240749 from USGS Mesozoic loc. 28682.

10. External and internal molds of laterally crushed hypotype, USNM 240748 from USGS Mesozoic loc. 28682. At least two-fifths of the outer whorl is nonseptate. 

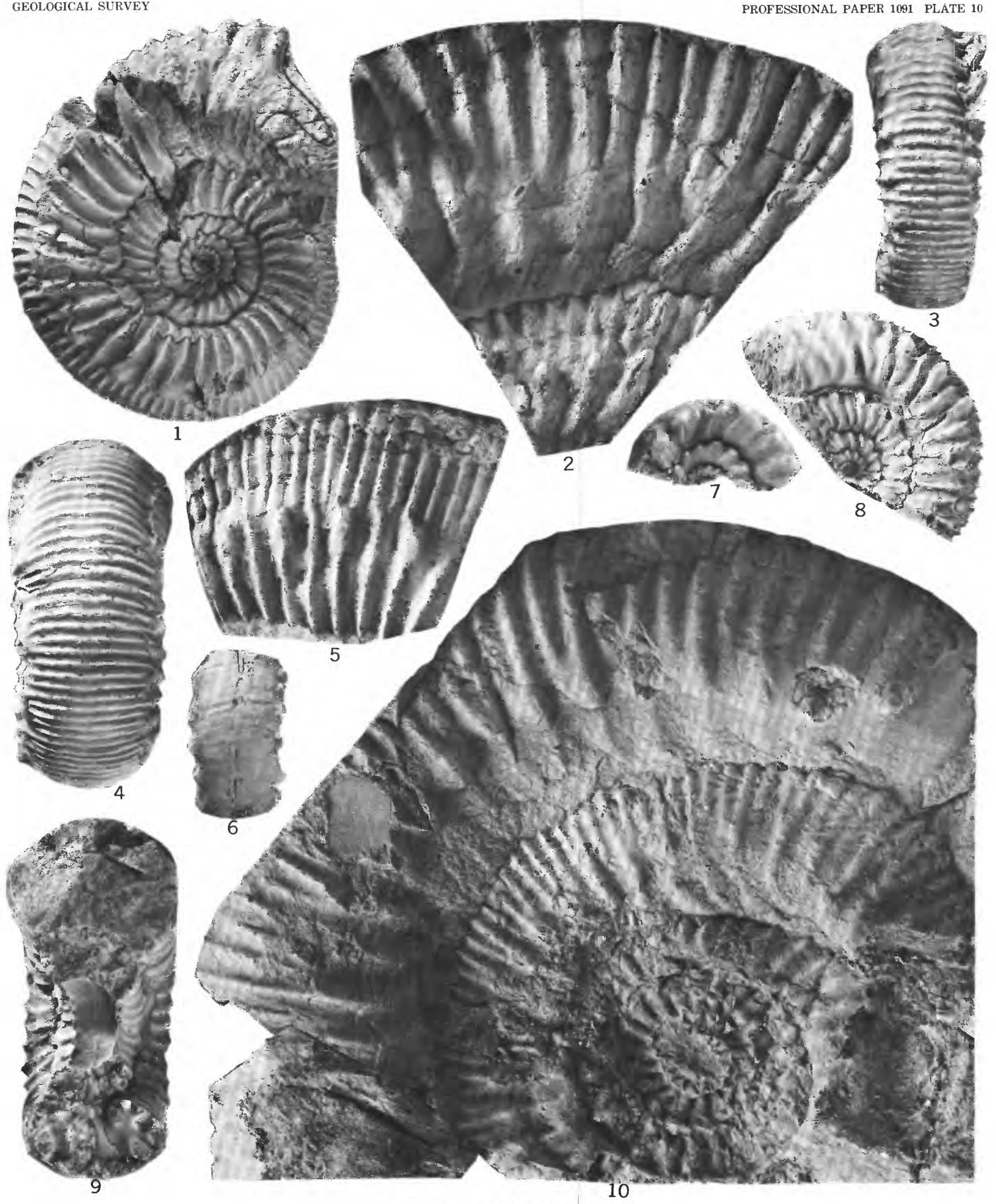

PARAREINECKEIA 


\section{PLATE 11}

[All figures are natural size]

Figures 1-16. Parareineckeia nelchinensis Imlay n. sp. (p. 36).

1. Rubber imprint of external mold of paratype, USNM 240754 from USGS Mesozoic loc. 28527.

2-5. Internal mold of immature paratype, USNM 240760 from USGS Mesozoic loc. 3038.

6. Laterally crushed paratype, USNM 240756 from USGS Mesozoic loc. 28682.

7, 13-16. Holotype, USNM 240753 from USGS Mesozoic loc. 30272. Figures 7 and 14 represent the septate whorls. On figure 16 about half of outer whorl is nonseptate.

8. Laterally crushed paratype, USNM 240755 from USGS Mesozoic loc. 28527. Probably represents part of adult body chamber.

9. Laterally crushed paratype, USNM 240759 from USGS Mesozoic loc. 28524.

10, 11. Paratype, USNM 240758 from USGS Mesozoic loc. 28682.

12. Paratype, USNM 240757 from USGS Mesozoic loc. 28682. 
GEOLOGICAL SURVEY
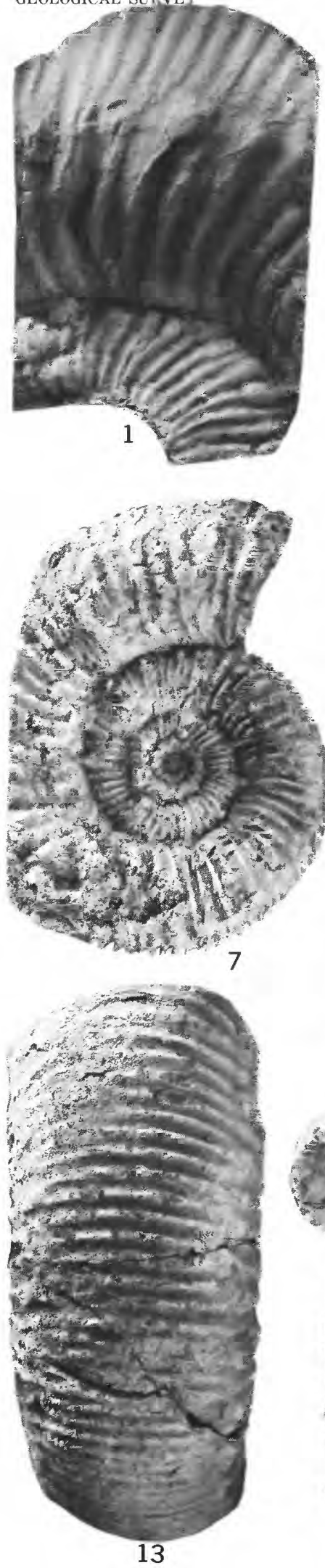

13
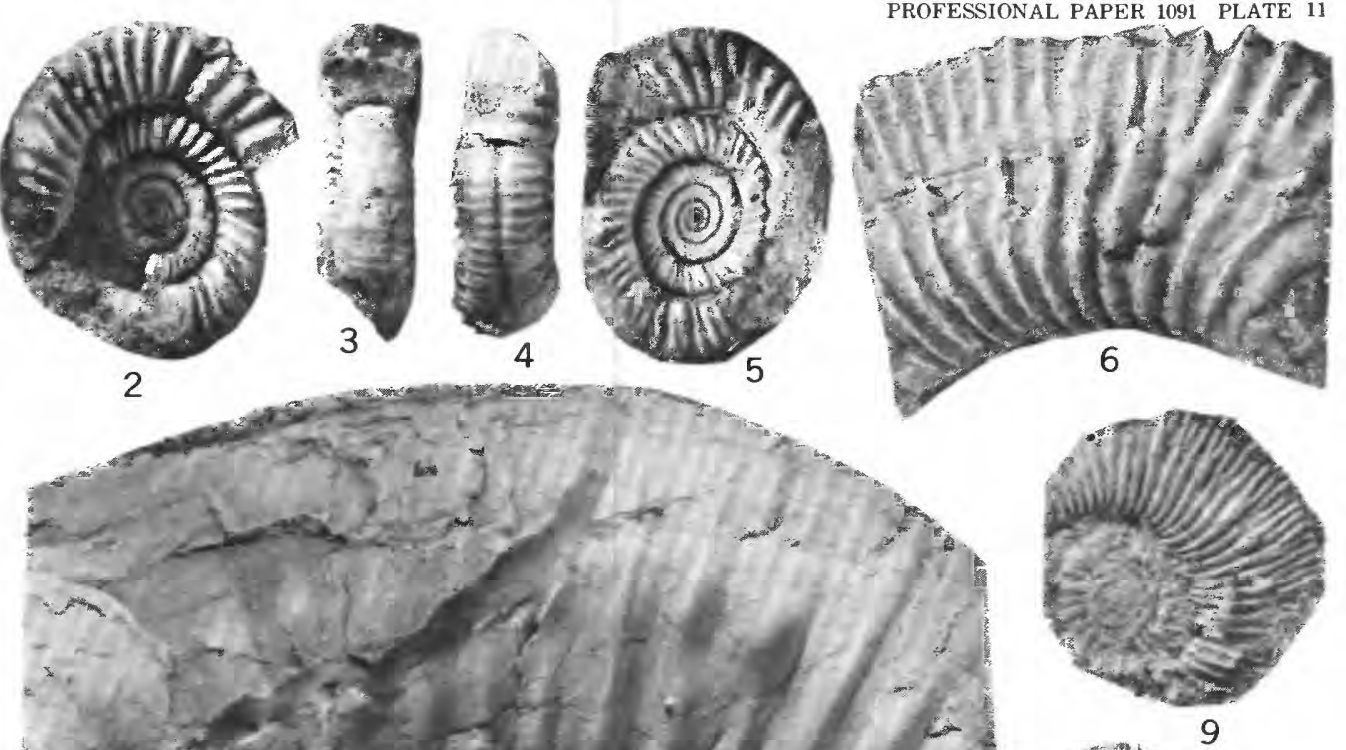

9
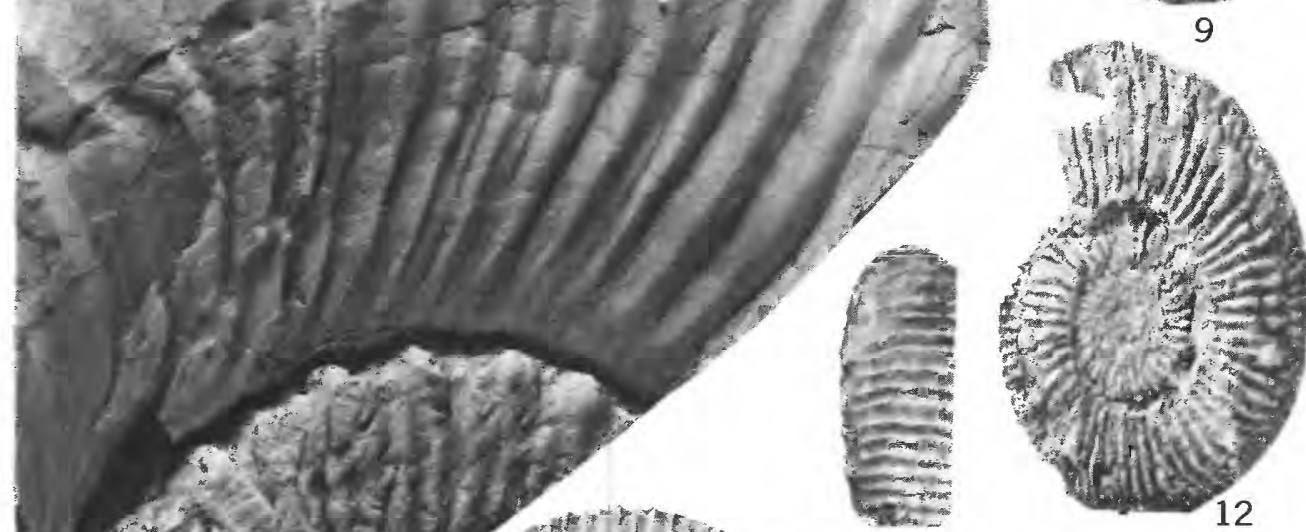

(T)

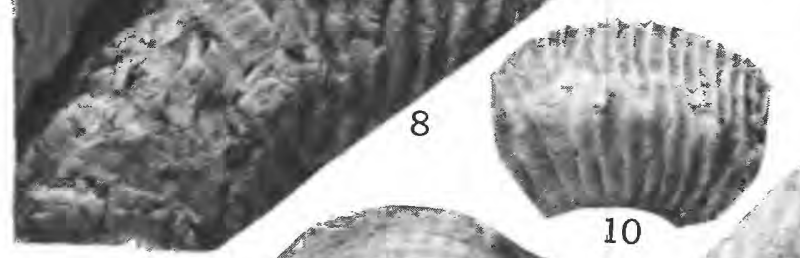

11

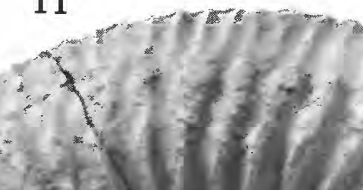

.
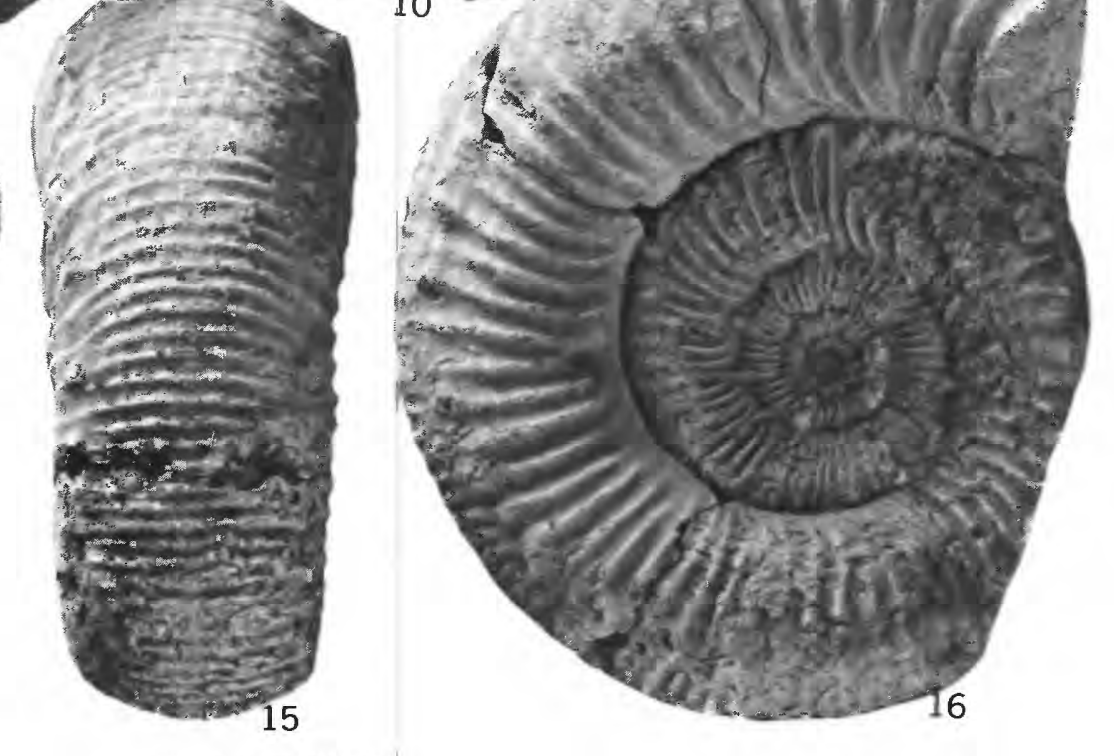

PARAREINECKEIA 


\section{PLATE 12}

[All figures natural size except suture lines]

Figures 1, 5, 10, 11. Cobbanites striatus Imlay n. sp. (p. 37).

1. Internal and external molds of holotype, USNM 240764 from USGS Mesozoic loc. 28682.

$5,10,11$. Internal mold of immature paratype, UCLA 4988 at loc. RAL 65.

2-4, 7-9. Cobbanites talkeetnanus Imlay (p. 37).

24. Hypotype, USNM 240761 from USGS Mesozoic loc. 30277.

7. Hypotype, USNM 240762 from USGS Mesozoic loc. 28699.

8, 9. Hypotype, USNM 240763 from USGS Mesozoic loc. 28525.

6, 12-15. Cobbanites tuxedniensis Imlay n. sp. (p. 37).

Holotype, USNM 240765 from USGS Mesozoic loc. 30261. Figure 6 shows suture line $(\times 2)$ drawn at diameter of $80 \mathrm{~mm}$. Figure 12 shows a ventral view at diameter of about $67 \mathrm{~mm}$. Figure 13 shows a ventral view at diameter of $80 \mathrm{~mm}$. 
GEOLOGICAL SURVEY

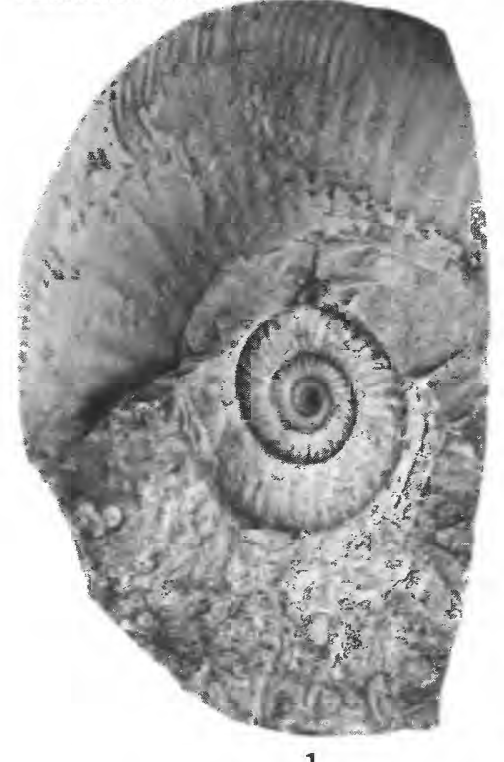

1

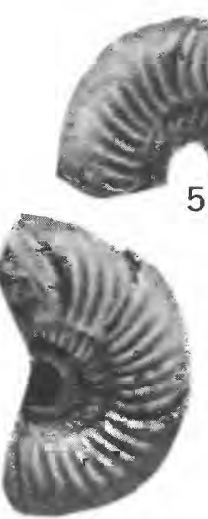

10

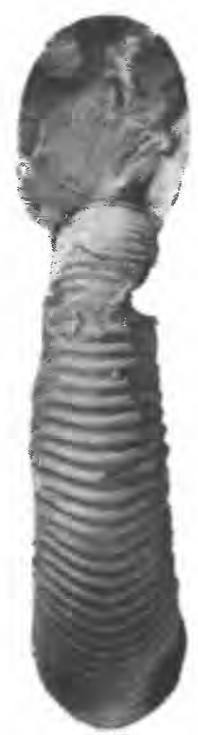

12
5
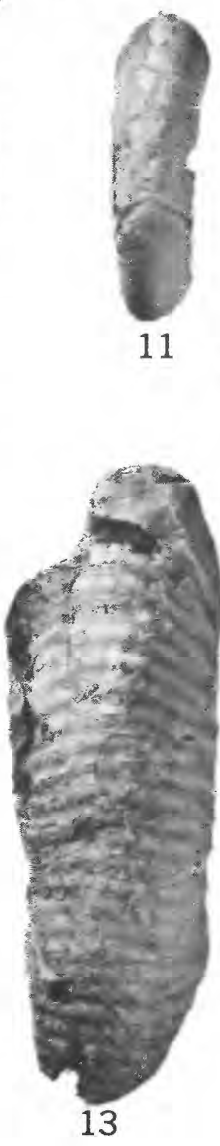
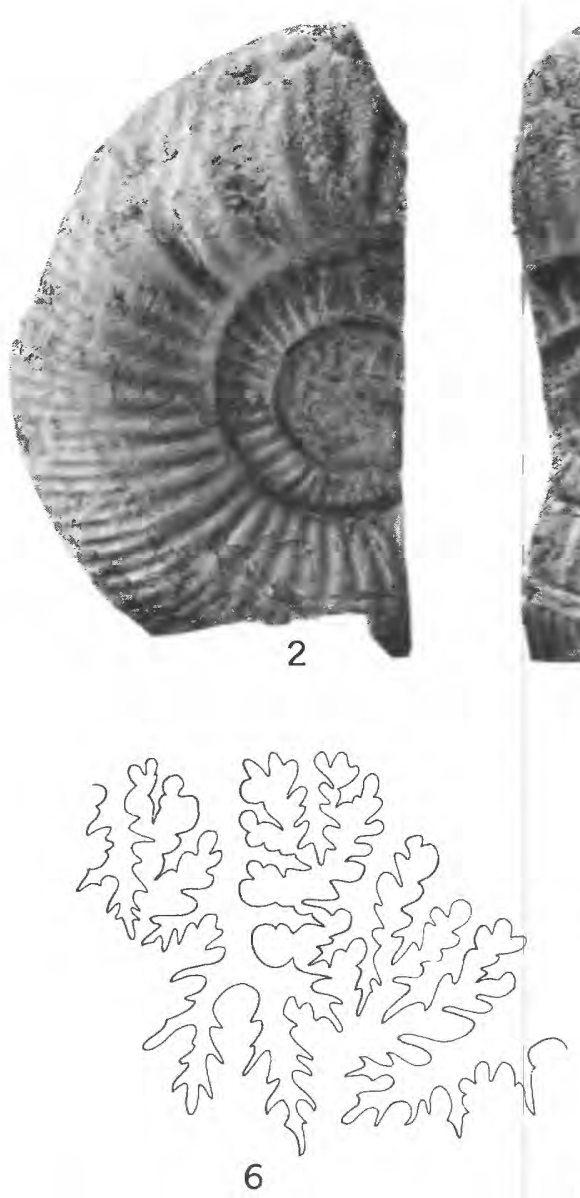
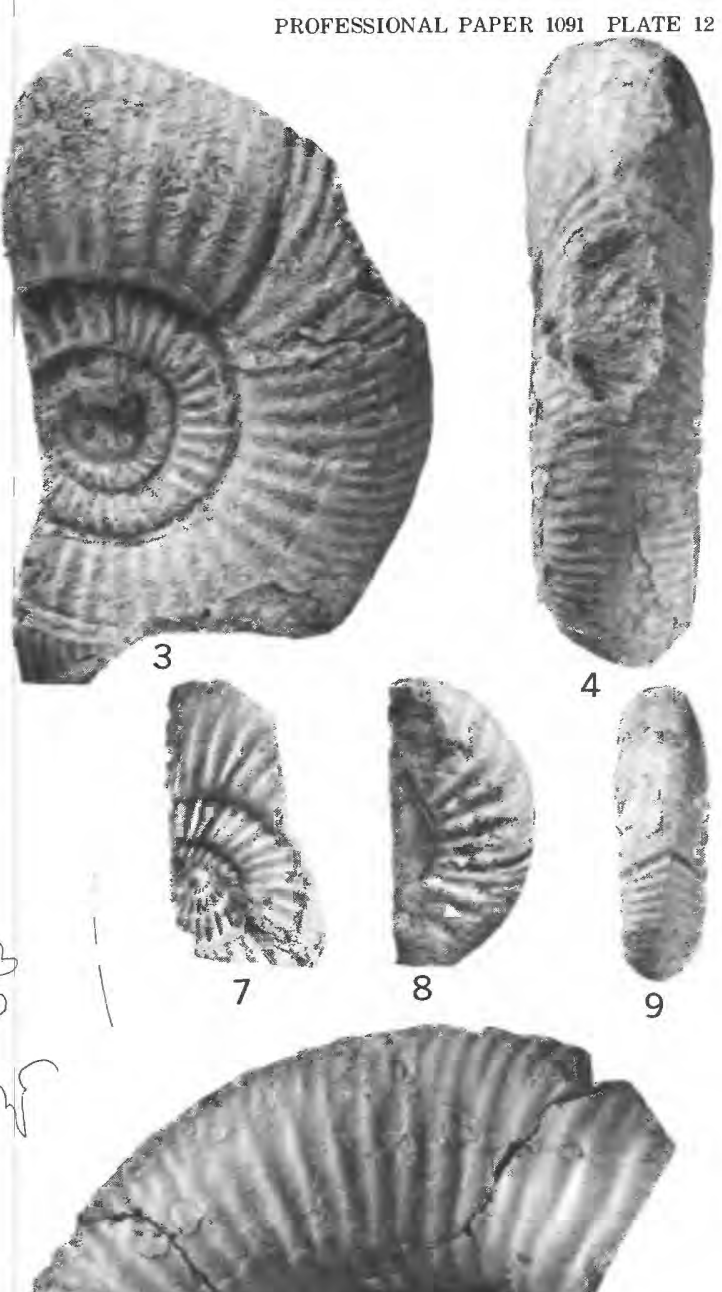

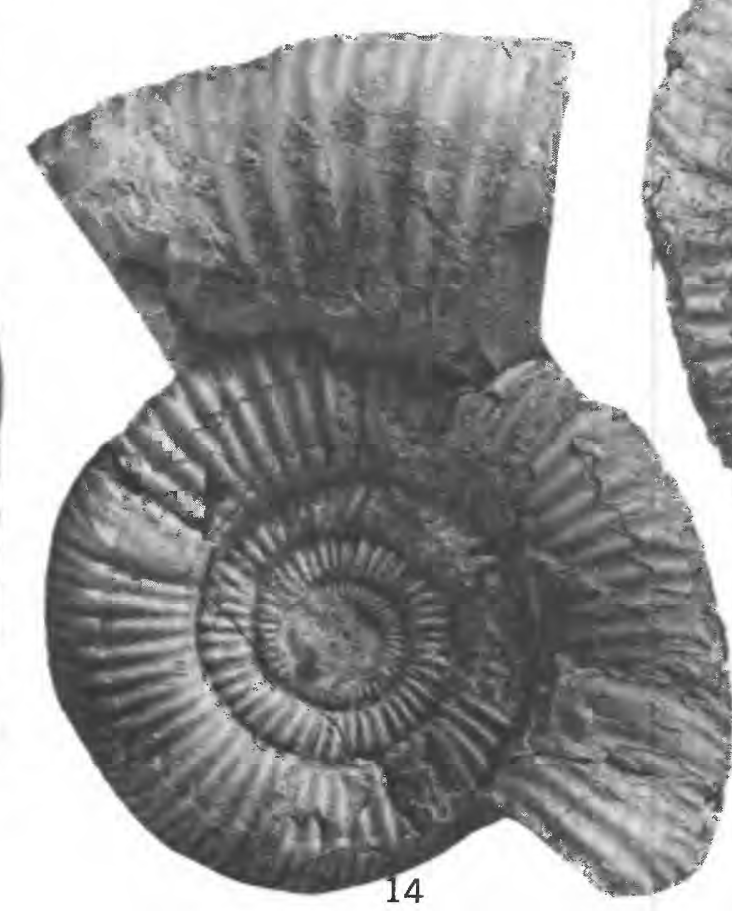

COBBANITES 